Historic, Archive Document

Do not assume content reflects current scientific knowledge, policies, or practices. 



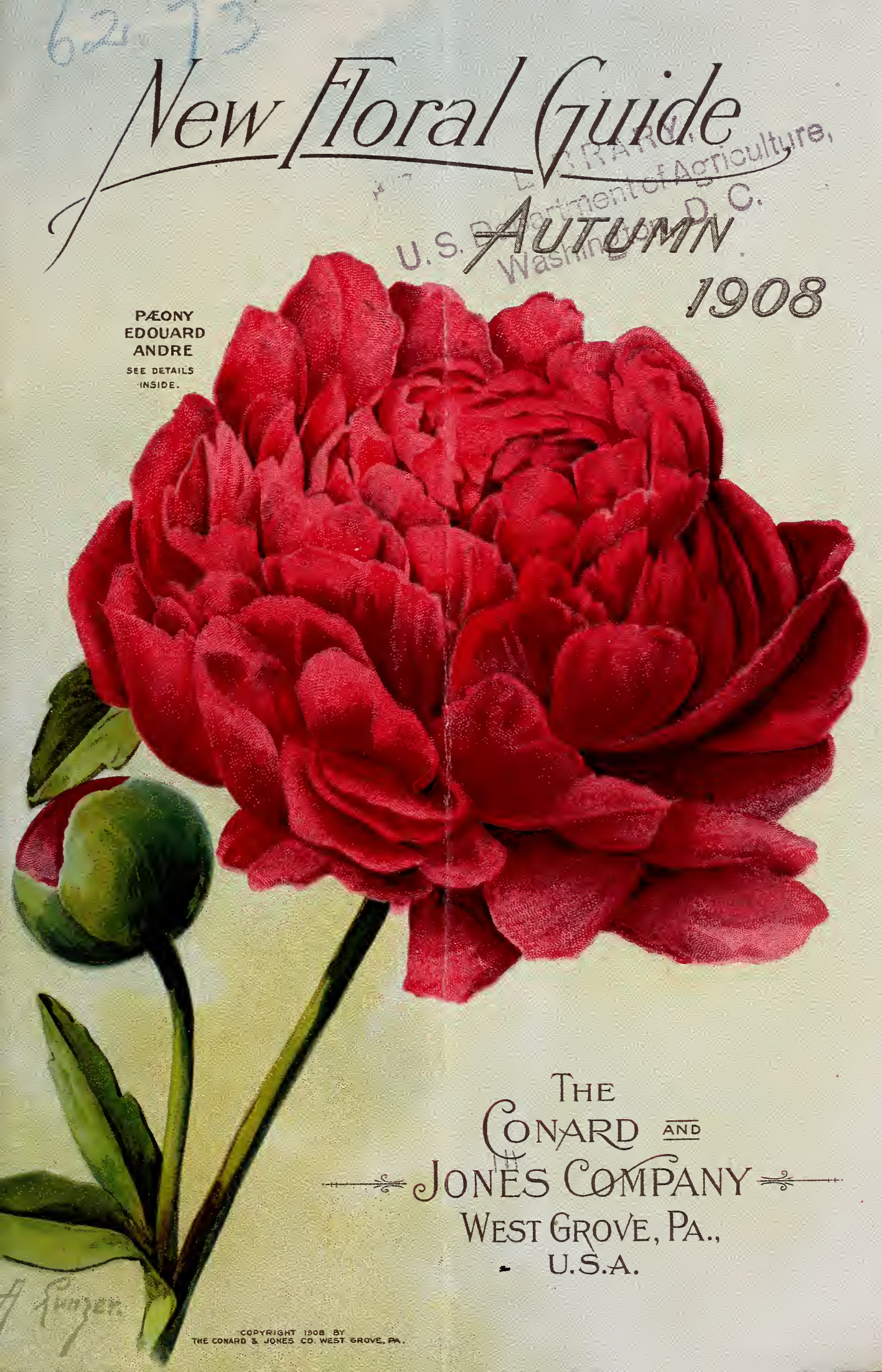




\section{“EVERYBODY'S FLOWER"}

(See front cover page)

WHY ? Because so universally suited to planting almost anywhere, and for almost every purpose. "King of the Flowers." Because it combines more qualities of majestic beauty, gorgeous colors and easy culture than any other flower you can get. For big dividends in beauty and fragrance, even if your soil is poor and your summers hot, we recommend an investment in this "Aristocrat of the Flower Family" the Hardy Herbaceous Peony-Everybody's Flower.

Read what The Garden Magazine says:

\section{WHY GROW PEONIES?}

There are at least seven good reasons for the popularity of the herbaceous peony :

1. It is easy to grow ; anybody can raise glorious peonies with less trouble than it takes to grow good roses.

2. A peony well established is as permanent a feature in the garden as is desirable in a herbaceous plant.

3. Peonies are perfectly hardy wherever apples can be grown, passing through the most severe winters without injury.

4. The blooms are large, showy, of various forms, and in any shade of color from white to purple.

5. Almost all varieties are fragrant.

6. It is practically free from disease and insects. No spraying or dusting or hand picking of worms is necessary.

7. It is equally successful as a cut flower and for artistic landscape effects.-Garden Magazine.

\section{How, Where and When to Plant.}

The Peony will grow well on almost any well drained fertile soil, but it does it's best on a rather heavy moist loam.

Make the ground rich, for the Peony is what gardeners term a "gross feeder." The roots also like plenty of water. Plant in the Autumn, 2 to 3 feet apart, with the crowns 2 to 3 inches below the surface, and press soil well about the roots.

A clump well established will last from 20 to 40 years. But it pays to take them up. divide the roots and replant them every 7 or 8 years.

Oblong beds- -3 rows wide, make grand displays-but better still, plant generously along your porch or walk, or in front of shrubbery border.-Garden Magazine.

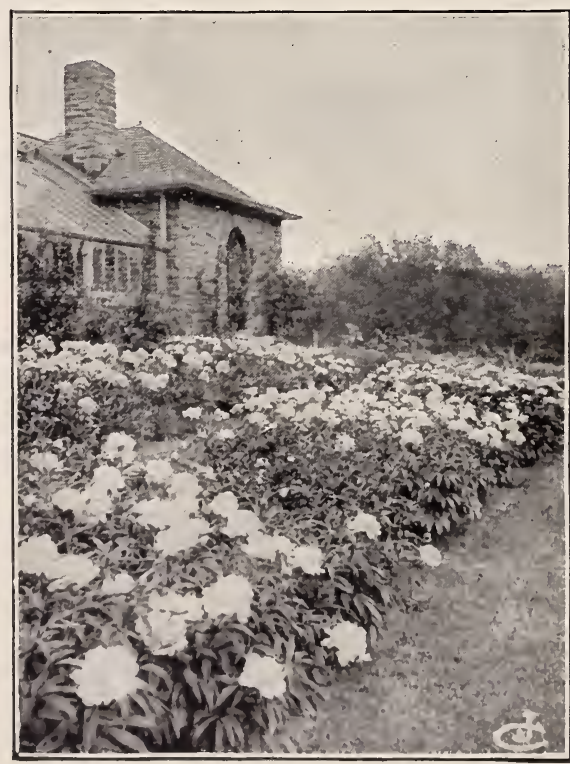

Peonies Make a Gorgeous Mass of Bloom.

\section{PEONIES ) Price,}

$\left.\begin{array}{l}\text { PEONIES } \\ \text { NOT NAMEI) }\end{array}\right\}$ Red, White or Pink $\left\{\begin{array}{l}\text { Price, } \\ 20 \text { cts.each, } \\ \text { postpaid. }\end{array}\right.$

\section{Choice Peonies}

EDOUARD ANDRE. Gloriously beautiful, large, globular flowers-of deep crimson red-shaded almost black-reflex of the petals fairly shine with a metallic lustre. One of the most striking and magnificent. Early. (See front cover page). \$1.00 each, postpaid.

DUCHESS DE NEMOURS. (Calot) Guard petals, white, center lemon yeilow with greenish reflex, a good free bloomer, and in the half open state most exquisitely chaste of them all. 60c. each, postpaid.

NOBILISSIMA. Imagine the most exquisite coloring of delicate rosy lilac shading into a darker tone. 60c. each, postpaid.

SPECIAL OFFER NO. 1. ABOVE THREE, \$1.50 $B Y$ EXPRESS; $\$ 1.85$ POST PAID.

\section{STANDARD PEONIES}

Andre Lauries-Rosy-red. Very free late bloomer; an old, wellknown variety, still in high favor.

Agnes Mary Kelway-Light-rose guard petals with yellow petaloids, bearing a lovely rose tuft ; a tricolor bloom that is sure to win admiration.

Canari-Outer petal white with deep primrose centre. It blooms earliest of all the light colored Peonies.

Charlemagne-Creamy white, center light lilac-flesh. with chamois, late and exceptionally fine.

Humei-Very large, compact and striking cherry-pink flowcr ; grown largely for cut flowers

L 'Esperance-Lovely rosc-pink, full fragrant, and early

Rubra Superba-Very large, rich, brilliant crimson. (one of the finest.)

Whitleyi-A fine white ; onc of the earliest to bloom.

Price for above Standard Varieties, 25c each; $\$ 2.50$ per dozen, Post Paid.

SPECIAL OFFER NO. 2. Entire 8 for $\$ 1.75$ by express, or $\$ 2.25$ delivered in $U$. S. A.

\section{PEONY OFFICINALIS}

These are the real old-fashioncd peonies of our Grandmothers' days. They bloom earliest of all. The flowers are large, full, double and fragrant. Thrce varicties.

Rosea-Bright rose-pink Rubra-Brilliant, slowing deep crimson.

Price, 25c, each post paid.

SPECIAL OFFER NO. 3. The above 3 Peonies for 65c., post paid. 


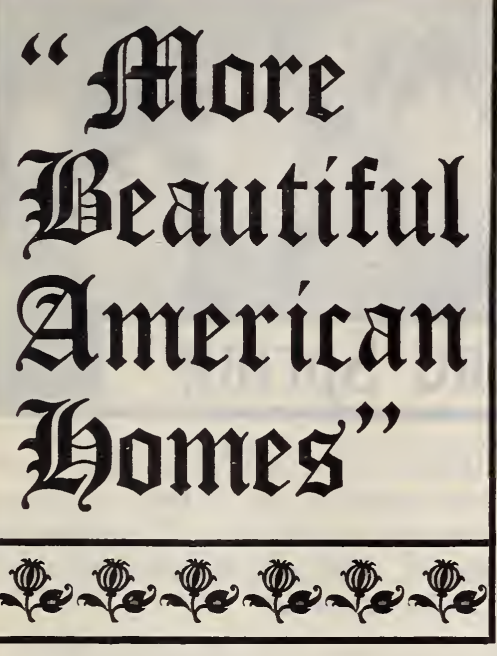

THAT is what we are working for.

And dear reader-do you know what a tremendous awakening there has been in this cause all over our great country?

The magazine makers know it and the best of them are telling you every month "How to beautify with plants and flowers."

Civic clubs and associations with "clean up and beautify" as their crusade cry, are springing up in the hamlets and towns of almost every State in the Union. We get letters from these people asking for plants, and it is surprising how many there are.

It is all a part of the great "out of doors" and "back to nature" movement, which is working wonders for the health and happiness of our people.

And THERE, dear reader, is just THE SECRET of its popularity--it's the joy, and the health, and the happiness which come with the growing of plants and flowers, which prove to people that IT PAYS to create for themselves and their families STILL MORE BEAUTIFUL HOME SURROUNDINGS.

How is it, dear flower-lover, around your own back door (or your front door if you'd rather)? Would flowers and vines help to beautify the outlook?

When you are ready, please remember that WE ARE HERE TO HELP YOU :

1. WITH AN ASSORTMENT which includes the kinds best worth growing. (See Index, page 42.)

2. WITH A QUALITY IN OUR STOCK which comes only from a lifetime's experience in handling plants (or rather the life experience of many men in our case).

3. WITH AN UP=TO=DATE business equipment and an earnest desire to see that you get what you want, and good measure.

May we help you this Fall? Please order early.

Faithfully, THE CONARD \& JONES COMPANY.

\section{INFORMATION FOR PURCHASERS}

Please use the Printed Envelope and Order Sheet, and be sure to write your full name and address clearly and plainly, and always the same way (Mr., Mrs., or Miss).

Always forward cash with your order, preferably by P. O. or Express Money Order, Registered Letter or Bank Draft. Postage Stamps accepted for small amounts.

FREE DELIVERY IN THE UNITED STATESAt the prices given in this Catalog, we deliver all bulbs and seeds free of charge, by mail or express (at our option), also all plants suitable to go by mail, but when plants are sent by express, either by request of the purchaser or because too large to go by mail, the purchaser must pas the express charges.

Canadian and Foreign orders should be accompanied with 20 per cent. extra payment to cover additional cost of packing and postage.

The Assortment of Bulbs and Plants we offer sidered, unexcelled. (Index, Fall planting is, size conof our goods is "right up." It was this quality that won for us the Highest Awards at St. Louis World's Fair, 1904. As to our RELIA BILITY ask any Bank or Mercantile Agency in the United States, or better still, ask our customers.

\section{PREMIUMS NOT ALLOWED}

on Special offers, Collections, nor items bought at dozen rates or seeds by weight or in bulk, but customers may select premiums on all things bought at single rates as follows:

On \$1.00's worth of goods bought at single rates,

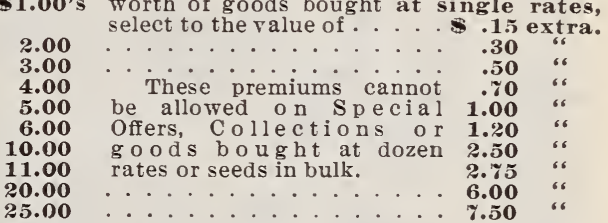

We should be glad to hare you state your preference, which we will follow so far as our stock permits.

All our customers can rely on getting good value, and liberal and satisfactory treatment in every way.

We Guarantee that everything you order from Catalog and will reach you in first-class condition anywhere in the United States. When anything is not right, advise us promptly and we will make it so. We hare been practicing this erer since we began business and beliere it is the foundation of our success. We hope you will examine our offers and send us your orders.

\section{An Innitation}

Our Nurseries are balf way between Philadelphia and Baltimore on P. R. R. During the Summer we have many acres of flowers in bloom. Visitors always welcome. Hoping that we may count upon you as a regular patron, we are Always faithfully yours,
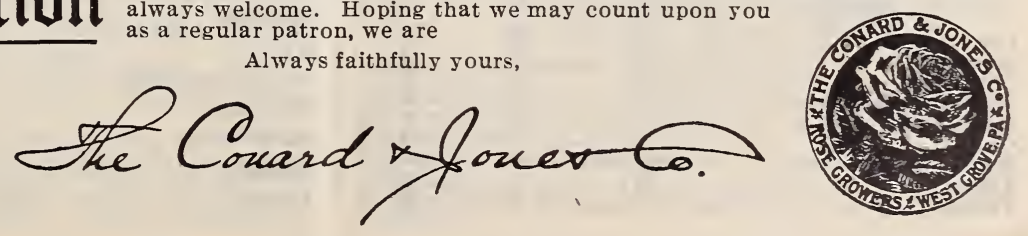


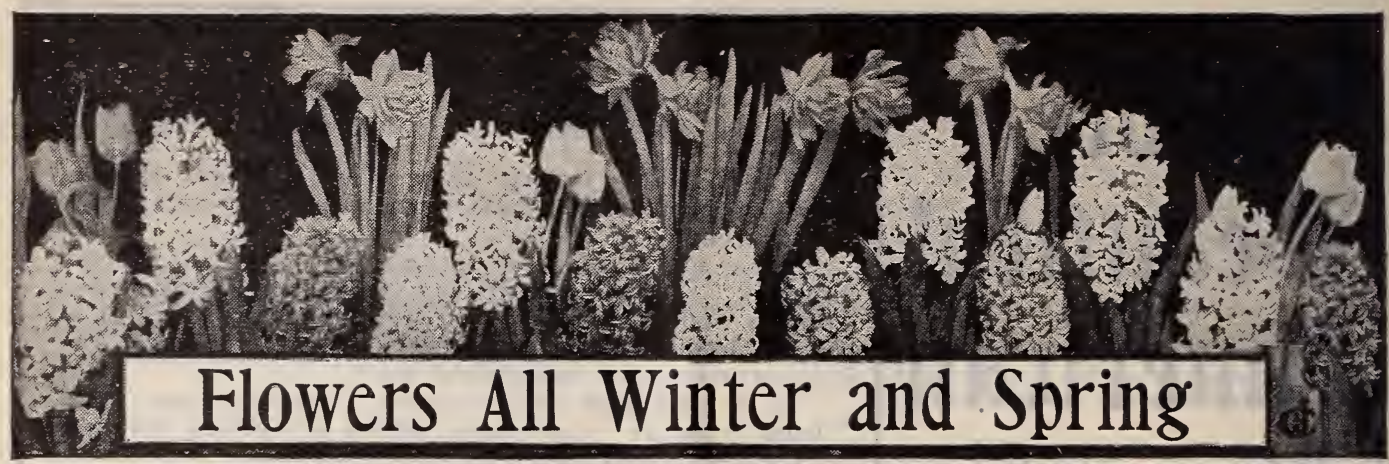

Flower lovers know the joy and satisfaction to be found in growing flowers from Bulbs-the demand for them is increasing annually. No other flowers grow so easily or are so sure to bloom. One can have a wealth of fragrance and beauty all through the dull days of Winter. Do you realize it-reader? And better still, their time of bloom can be regulated. Can you imagine any more delightful gift for the holidays or Christmas time than a box of Bulbs in bloom?

It is easily managed. Note the following simple directions.

For Growing Indoors Use good garden soil admixture of sand. The best soil is composed of rotted sods, rotted manure and sand. If manure is not available use "Bonora," the plant food offered on circular in this book.

Use bulb pans, pots or boxes, and provide for drainage ; then fill with soil to within two inches of the top, and place the bulbs, spacing them as indicated in schedule below. For indoors it is not too close if they nearly touch each other. Then cover with soil and see that it is thoroughly firmed down. Allow room at the top for watering, which do at once, and set bulbs a way in a cool dark place (say cellar, cold frame or pit) and cover box or pot and all with damp sand or ashes. This is to develop strong root,growth.

Keep them there until within 3 or 4 weeks of the time you want them to flower, then bring them gradually to the light and heat. Do not allow the soil to become dry at any time.

For the Garden Dutch Hyacinths, Tulips, CroIris, Snow Drops, etc. (see pages below), are the best flowers for early Spring bloom, and beautiful they are, but they must be planted in the Autumn. The sooner in October the better, or any time till the ground freezes. Plant in well-manured, good garden soil at depth and arranged as indicated in the schedule below. The bulbs are quite hardy, but will be the better for a good covering of leaves, litter or manure before hard freezing. This should be removed in the Spring when growth starts and before the weather gets warm.

\section{USEFUL PLANTING}

\section{FOR INIDOOIS}

Allium

Calla,

Chionodoxa

Crocus,

Freesia,

Grape Hyacinth.

Hy acinth, Bedding,

Miniature

Named.

Iris Spanish,

Jonquils,

Lilies,

Lily of the Valley.

Narcissus,

Oxalis,

Snow Drons.

Tritelcia,

Tulips, .
Thuibs i f or Indoor Winter Flowering may be grouped in order of bloom about as follows: Roman Hyacinths, Paper White Narcissus, Oxalis and Sacred Lily. A little later come the White Callas Freesias, Jonquils and Duc Von Thol Tulips. Then throughout midwinter and into Spring come the stately Dutch Hyacinths, the nodding Tulips, Narcissus and the lesser bulbs.

\section{After Blooming bulbs mas be left where they} (Pansies or Forget-me-nots from seeds sown in the same bed the Fall before will come on after the bulbs are done and make a fine second crop of beauty); or, if the bed is wanted for other flowers allow bulbs to mature, lift and dry them, and store away as you would onions, till wanted again in the Fall.

Hy acinths and Tulips are not likely to bloom so well the second season.

Bulbs for Naturalizing are becoming much recent years. Narcissus, Crocus and Daffodils, Snow Drops, Grape Hyacinths and Chionodoxas do splendidly when planted in the turf or sod; a void straight rows. Try scattering them about and plant them where they fall. Use a dibble and fill the bottom of the inverted coneshaped hole thus made with sand, but plant bulbs at usual depths. These should then continue blooming season after season till by increase they become too crowded, and will need to be reset. Thus in time you can have regular little colonies of flowers (see illustration on page 22).

\section{TABLE FOR BULBS}

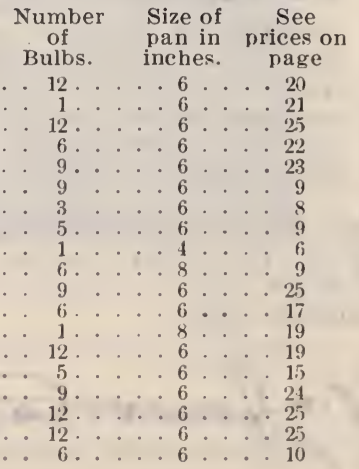

\section{FOR OUTDOOIR}

Allium,

Chionodoxa,

Crocus,

Hyacinth, Named,

Grape Hyacinth,

Iris, Spanish,

J onquils,

Lilies,

Lily of the Valley.

Narcissus,

Snow Irops

'Triteleia,

Tulips,

\section{Distance Depth See inches. inches. prices o}

20

- 25

22

6 


\section{HOW}

In the Open Ground

They should be planted in the Fall 6 inches a part each way and 3 to 4 inches deep. Give them slight protection over Winter and they will flash forth in beautiful bright colors early in the Spring and remain in bloom some weeks. Then the Bulbs may be removed in time to set your Summer flowering plants. Or in some soils,
Bulbs do well a number of years withBulbs do well a number of years with-
out lifting or replanting. So that in the same bed one may sow or set out shallow rooting plants such as Petunias, Verbenas and Portulacas which will produce a s e c ond season of bloom and in no way hurt the Bulbs.

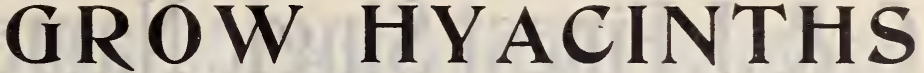

In Pots or Window Boxes

Hyacinths potted in September may be brought to bloom by Christmas, and by successive plantings a succession of bloom may be had until Easter. Plant the Bulb in the pot so that its crown just shows, then when finished set away in a cool dark place for 6 weeks or 2 months for root growth to develop. After this bring gradually to the light, heat, and air, and give plenty of water, and you will be well repaid.

\section{In Glasses}

All Hyacinths succeed well in water. If $\mathrm{Hyacinth}$ glasses are not available use pebbles or shells to keep the Bulbs in place and then set the Bulb so that the lower end is almost but not quite in contact with the water. It is not essential to change the water; a small lump of charcoal in the bottom will serve the same purpose. Put away in a cool dark place till you see the roots developed, then remove by degrees to full light and air.

HYACINTHS

are Invaluable for Indoor Decoration

\section{WE OFFER 4 DIFFERENT GRADES OF HYACINTHS AS FOLLOWS}

Extra Choice Named Hyacinths, Finest grade (Pages 6 and 7)

First Size Named Hyacinths, Best for general planting (Pages 6 and 7 )

Standard Named Hyacinths, Excellent for general planting (Pages 6 and 7 )

Hyacinths in separate colors, not named (Page 8).

\begin{tabular}{|c|c|c|}
\hline Each & Doz. & 100 \\
\hline$\$$ & $\$$ & $\$ 15$ \\
\hline & 1. & 12.00 \\
\hline .07 & $\begin{array}{r}1.20 \\
.70\end{array}$ & $\begin{array}{l}9.00 \\
5.00\end{array}$ \\
\hline
\end{tabular}

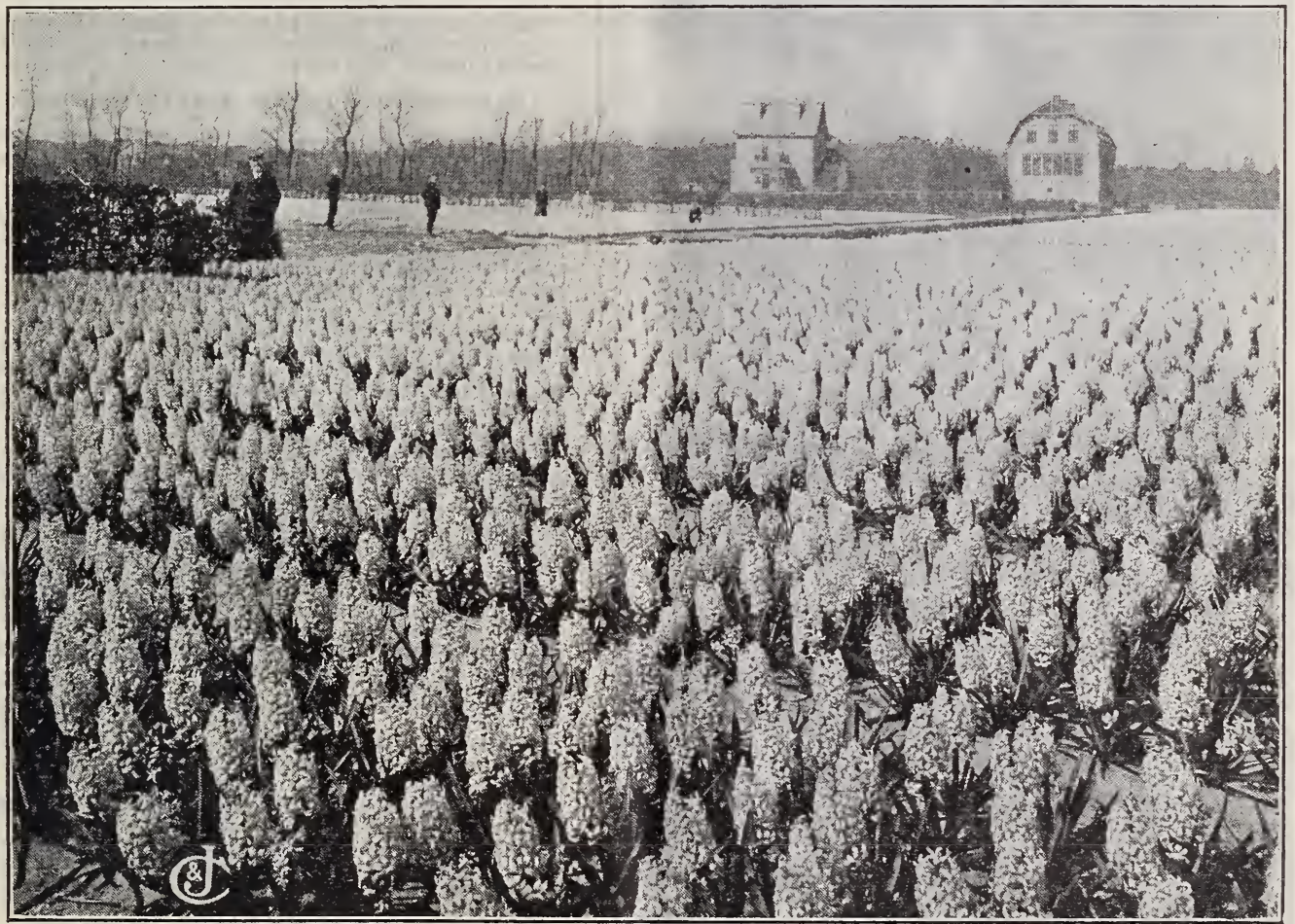

A Field of C. \& J. Hyacinths as They Are Grown in Holland

\section{C. \& J. COLLECTIONS OF CHOICE HYACINTHS}

Bed No. 101-10 Single Hyacinths, \$1.00, or any 5 for 60 cents, prepaid

Dark Rose and Red-Gigantea, Roi des Belges.

Pink a1d Blush-Gertrude, Grandeur a'Merveille.

White-Baroness von Thuyll, Queen Victoria.

Purple-Marie.

Yellow-Obelisk.

Lavender and Blue-La Peyrouse, Chas. Dickens.

Bed No.102-12 $\left\{\begin{array}{c}\text { Single and } \\ \text { Double }\end{array}\right\}$ Hyacinths, \$1.50, or any 6 for 80 cents, ppd.

Dark Rose and Red-(Sgle.) Maria Cornelia; (Dble.) Lord Wellington.

Pink and Blush-(Sgle.) Moreno; (Dble.) Anna Maria. White-(Sgle) La Grandesse; (Dble) La Tour d'Auvergne. Purple-(Sgle.) King of the Blues; (Dble.) Chas. Dickens. Yellow-(Sgle.) Ida; (Dble.) Supreme Yellow.

Light Blue-(Sgle.) Grand Maitre; (Dble.) Blocksberg
Bed No. 103-12 Single Hyacinths, \$2.00, or 1 of each, 6 for $\$ 1.00$, ppd.

Dark Rose and Red-2 Cardinal Weisman, 2 General Pelissier.

Pure White-2 La Grandesse, 2 Mad. Van der Hoop.

Yellow and Orange -2 Bird of Paradise.

Lavender and Light Blue-2 Grand Maitre.

Bed No. 104-12 Double Hyacinths, \$1.75, or any 6 for $\$ 1.00$, ppd.

Dark Rose and Red $\{$ Princess Royal.

Pink and Blush-Czar Nicholas, Anna Maria.

Pure White-Florence Nightingale, La Tour d'Auvergne. Tinted White-Bouquet Royal.

Lavender and Light Blue - Blocksberg and Chas. Dickens.

Yellow and Orange - Bouquet d'Orange, Supreme Yellow. 


\section{C.\& J.Finest Single Named Hyacinths}

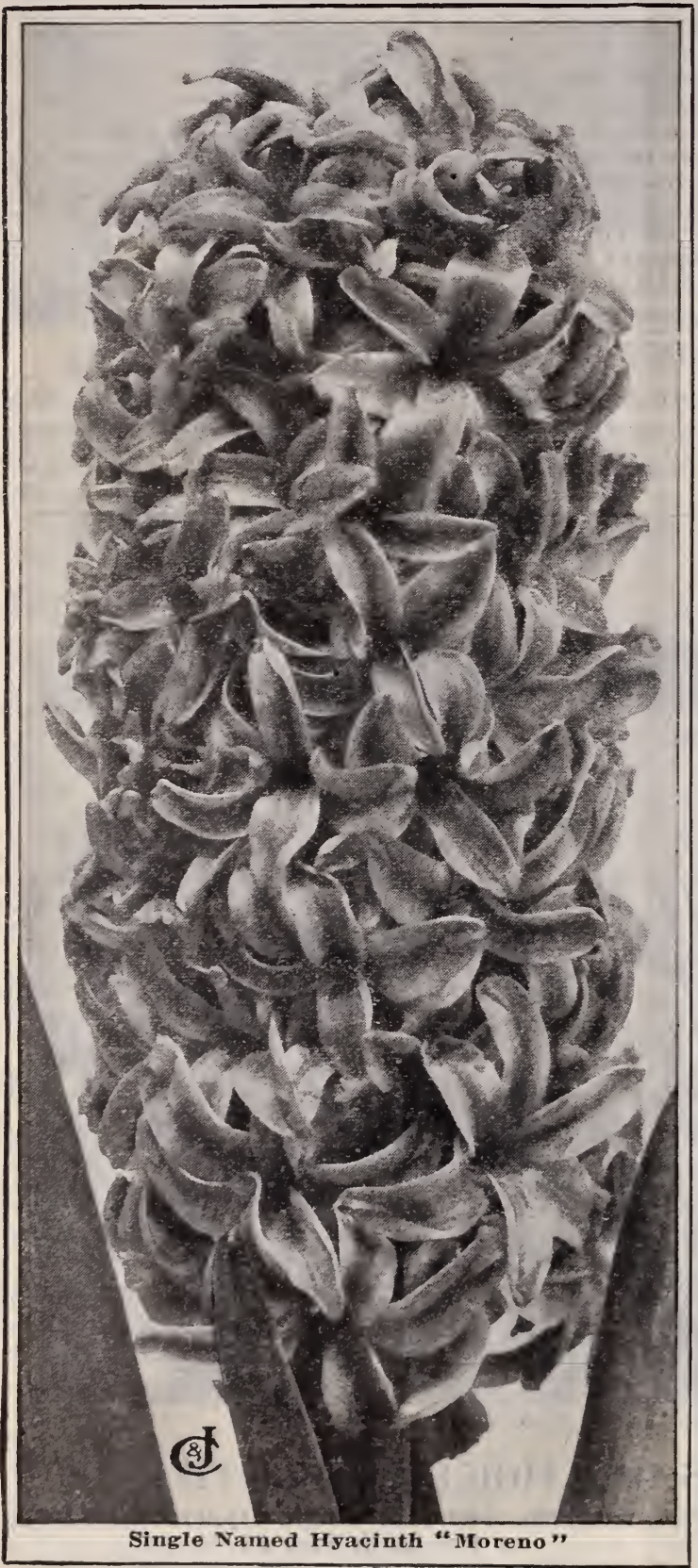

6 at dozen rates, 25 at 100 rates

\begin{tabular}{ll|l|l|} 
& 100
\end{tabular}

Charles Dickens (2)-Bright blue

shading to lovely porcelain; large,

compact trusses; unexcelled for all

Grand Maitre (2)-Splendid 1 a $\mathrm{r}$ g e

spikes, pure ultramarine blue,

$\$ \$ 0.15 \$ \$ 1.50 \quad \$ 12.00$

La Peyrouse (3) - Fine violet blue,

large bells in grand trusses.

\section{Specially Selected for Choice} House Culture and Bedding

Of all the Winter and Spring Flowering Bulbs the Hyacinth is King. You can get them in nearly any color you wish: pink, red, yellow, orange and blue. from pure white and delicate tints to deep dyed purple; all very fragrant. They are of the easiest culture and sure to bloom because each bulb has the blossom already started and wrapped tight inside it when you get it. They will grow almost anywhere you plant them-indoors in soil or water, and will give gorgeous bouquets for Christmas week or other occasions. They remain in bloom a long time, and for table, window or mantel decoration or conservatory display they are exquisite. Equally as valuable, too, for outdoor culture.

The figures 1,2, 3 and 4 after the name of the $\mathrm{Hya}$ cinth indicate the relative time of flowering - the 1's flower together and are the earliest; No.4 the latest.

Delivered free in U. S. A. at these prices

\section{SINGLE HYACINTHS}

Single Dark Rose and Red Cardinal Wiesman-(1) Splen-

did rose pink flowers in large

handsome trusses

Gen'l Pelissier (1)-Bright rich

glowing crimson; very beautiful,

Gigantea (2) - Deep rich rose,

fine large bells in extra large

regular trusses,

Maria Cornelia (2)-Fine bright crimson. Large, full spikes,

Roi des Belges (4)-Fine massive spikes crowded full of deep glowing, carmine flowers,

Single Pink and Blush

Gertrude (3)-Bright rosy pink, large erect spikes of beautifully formed flowers,

Grande ur a'Merveille (2)Beautiful blush white, extra fine large trusses, one of the very

finest of this lovely color,

Moreno (2)-Beautiful clear rose pink, large waxy flowers, extra fine trusses; carly bloomer

\section{Single Pure White}

Baroness Von Thuyll (1)-Pure

snow-white flowers in $1 \mathrm{arge}$ trusses,

La Grandesse (3) - One of the most beautiful of all the single pure white kinds; extra la rge,

Mad. Van der Hoop (2)-Beautiful, large waxy bells in splendid trusses; one of the finest, single pure white,

Queen Victoria (2)-Pure waxy white, extra large bells in im. mense trusses. A magnificent hy acinth.

Single Indigo and Purple King of the Blues (2)-Beautiful large trusses of dark blue flowers,

Marie (2)-Bright rich royal purple, with light blue stripes,

Single Yellow and Orange Bird of Paradise (2)-Beautiful rich yellow; extra fine in every way, . Ida (3)-Bright yellow, la rge fine trusses,
obelisk (4)-Pure deep yellow; one of the very finest of this color,

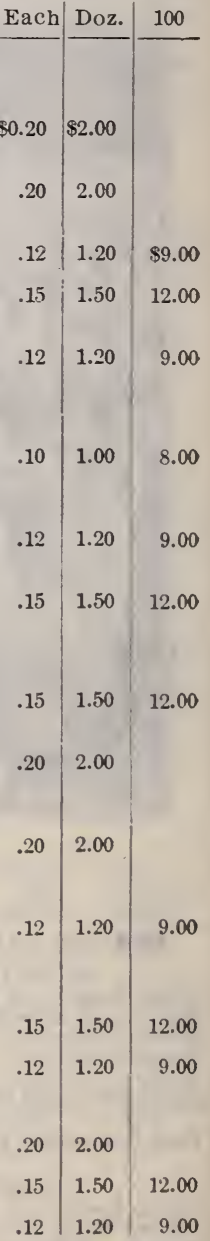

\begin{tabular}{l|l|l} 
Each & Doz. & 100
\end{tabular} $\$ 0.20 \$ 2.00$ $.20 \quad 2.00$ \begin{tabular}{l|l|l}
.12 & 1.20 & $\$ 9.00$
\end{tabular} \begin{tabular}{l|l|l}
.15 & 1.50 & 12.00
\end{tabular} \begin{tabular}{l|l|l}
.12 & 1.20 & 9.00
\end{tabular} 10 $.10 \quad 1.00$ 8.00 $.12 \quad 1.20$ 9.00 \begin{tabular}{l|l|l|}
.15 & 1.50 & 12.00
\end{tabular} \begin{tabular}{l|l|l}
.15 & $1.50 \quad 12.00$
\end{tabular} $.20 \quad 2.00$ $.20 \quad 2.00$ 1.20 \begin{tabular}{l|l|l}
.12 & 1.20 & 9.00
\end{tabular} \begin{tabular}{l|l|l}
.15 & 1.50 & 12.00
\end{tabular} \begin{tabular}{l|l|l}
.12 & 1.20 & 9.00
\end{tabular} $.20 \quad 2.00$ \begin{tabular}{l|l|l}
.15 & 1.50 & 12.00
\end{tabular} \begin{tabular}{l|l|r}
.12 & 1.20 & 9.00
\end{tabular}

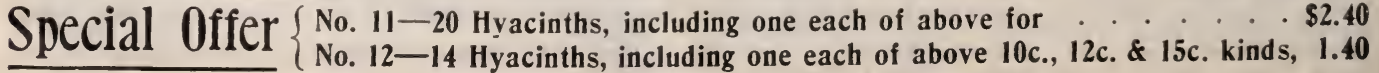




\section{C.\&J.Finest Double Named Hyacinths}

See numbers explained on page 6 .

6 at dozen rates, 25 at 100 rates

Prices delivered free in U. S. A.

Each Doz. 100

Double Dark Rose and Red

Lord Wellington (2)-Clear bright carmine, extra large and handsome in every way. One of the best and most beautiful of all.

Maria de Medicis (1)-Extra large and handsome semi-double flowers; deep carmine rose; grand spikes well furnished: one of the best,

Princess Royal (2)-Beautiful deep red, with fine dark center, double and fine. $A$ grand sort not surpassed by any,

\section{Double Pink and Blush}

Anna Maria (2)-Double blush white, with rich purple center, extra large trusses, a splendid sort. Very showy and handsome,

Czar Nicholas (3)-An exceedingly lovely kind; large bold trusses, delicate light pink shading to rosy blush; very sweet and handsome,

Grootvorst (2)-Extra large, handsome spikes of fine rosy pink flowers; very double. Always greatly admired by

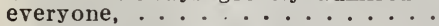

\section{Double Pure White}

Florence Nightingale (1)-Pure waxy white, large double bells; exceedingly beautiful,

La Tour d'A uvergne (2)-Double pure white, very rich and waxy, bloom $\mathrm{s}$ early, is one of the best kinds for all purposes,

Prince of Waterloo (1)-Extra fine double white flowers in large full spikes; deliciously sweet,

Double Tinted White

Bouquet Royal (3)-A grand variety, splendid large flowers in fine trusses: color, pure white, with rich yellow center; perfectly double, . . . . . . . .

La Virginite (2) - Fine medium-sized truss, l a rge d o u ble flowers; rich creamy white, delicately shaded to

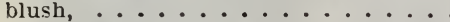

Double Lavender and Light Blue

Blocksberg (4)-Lovely porcelain blue, fine double flowers in large trusses: very beautiful,

Charles Dickens $(3)-D a r k$ violet blue, large full spikes of exquisite flowers; very double and sweet,

Duke of Norfolk (1)-Splendid bright blue with rich dark center, extra large truss; very early bloomer, .......

Garrick (2)-A truly magnificent sort, lorely azure blue flowers in large compact spikes; one of the very best, . .

Double Yellow and Orange

Bouquet d'Orange (3)-Exquisite rosy orange, elegantly shaded; fine semidouble flowers, rare and handsome.

Supreme Yellow (3)-Pure rich, golden yellow, very double and fine; one of the best double yellows.

William III (4)-Double yellow with apricot pink center, large handsome trusses, very beautiful,

-

$\$ 0.12 \$ 1.20 \$ 9.00$

\begin{tabular}{l|l|l}
.20 & 2.00 & 15.00
\end{tabular}

\begin{tabular}{l|l|l|}
.15 & 1.50 & 12.00
\end{tabular}

\begin{tabular}{l|l|l}
.15 & 1.50 & 12.00
\end{tabular}

\begin{tabular}{l|l|l}
.15 & 1.50 & 12.00
\end{tabular}

\begin{tabular}{l|l}
.12 & 1.20
\end{tabular}

9.00

$.20 \quad 2.00$

15.00

$.15 \quad 1.50$

$.12 \quad 1.20$

12.00

$.15 \quad 1.50$

12.00

\begin{tabular}{l|l|l}
15 & 1.50 & 12.00
\end{tabular}

$.20 \quad 2.00$

$.15 \quad 1.50$

15.00

$.10 \quad 1.00$

$.12 \quad 1.20$

8.00

9.00

\begin{tabular}{l|l|l}
.20 & 2.00 & 15.00
\end{tabular}

\begin{tabular}{l|l|l}
.15 & 1.50 & 12.00
\end{tabular}

\begin{tabular}{l|l|l|}
.15 & 1.50 & 12.00 \\
\hline
\end{tabular}

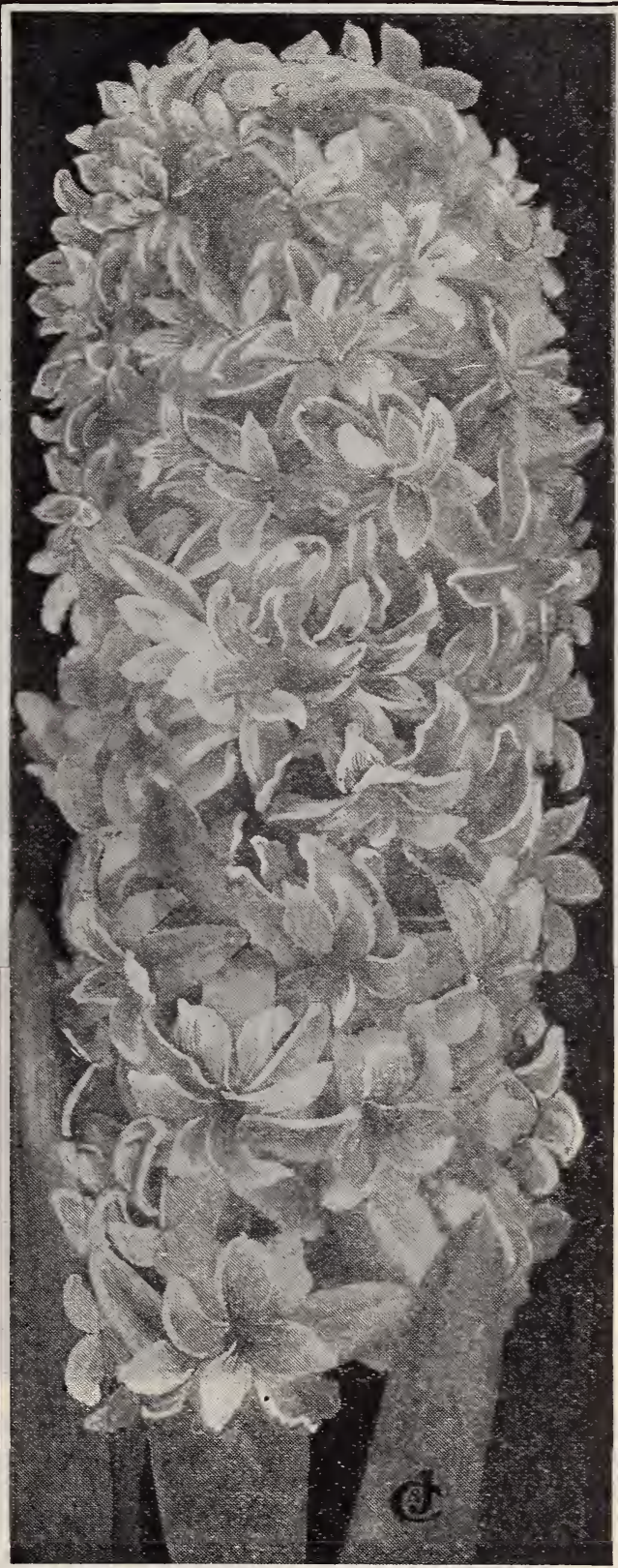

Double-Named Hyacinth "Lord Wellington"

\section{Special Offers for the Convenience of our Customers}

No. 13-18 DOUBLE HYACINTHS, including one each of above,

Prices delivered

No. 14-13

“

No. $15-6$

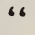

، one each of above, $12 \mathrm{c}$. and $15 \mathrm{c}$. kinds,

one $15 \mathrm{c}$. var. from each color class above,
$\$ 2.50$

1.50

.80 


\section{HYACINTHS IN SEPARATE COLORS}

Our Fine Selected Hyacinths in Separate Colors are good size, well matured Bulbs, sold at low prices and specially recommended for BEDDING and also for WINTER BLOOMING in the conservatory and window garden, when the higher priced kinds are not desired. They give excellent satisfaction.

\begin{tabular}{|c|c|c|c|c|c|c|c|c|c|c|c|c|c|c|c|c|c|}
\hline \multicolumn{7}{|c|}{ Prices delivered free in U. S. A. } & $\left|\frac{\mathrm{Each}}{\$ 0.07}\right|$ & Doz. & $\frac{100}{85.00}$ & \multicolumn{5}{|c|}{ Prices delivered free in U.S. A. } & $\mathrm{Each}$ & $\frac{\text { Doz. }}{\$ 0.75}$ & $\frac{100}{85.50}$ \\
\hline $\begin{array}{l}\text { Thite, } \\
\text { White, } \\
\text { ink, } \\
\text { ied, } \\
\text { lue, } \\
\text { lue, } \\
\text { ors mixed }\end{array}$ & $\begin{array}{c}\text { Single } \\
\text { 66 } \\
66 \\
\text { 66 } \\
\text { 66 "6 }\end{array}$ & 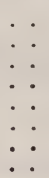 & : & 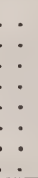 & & & $\begin{array}{r}\$ 0.07 \\
.07 \\
.07 \\
.07 \\
.07 \\
.07 \\
.07 \\
.06\end{array}$ & $\begin{array}{r}\$ 0.70 \\
.70 \\
.70 \\
.70 \\
.70 \\
.70 \\
.70 \\
.55\end{array}$ & $\begin{array}{l}\$ 5.00 \\
5.00 \\
5.00 \\
5.00 \\
5.00 \\
5.00 \\
5.00 \\
4.35\end{array}$ & $\begin{array}{l}\text { White, } \\
\text { White, } \\
\text { Pink, } \\
\text { Red, } \\
\text { Blue, } \\
\text { Blue, } \\
\text { w, } \\
\text { lors mix }\end{array}$ & $\begin{array}{r}66 \\
66 \\
66 \\
66 \\
66 \\
66,66 \\
\end{array}$ & 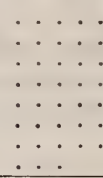 & & . & $\begin{array}{l}.0 \\
.0 \\
.0 \\
.0 \\
.0 \\
.0\end{array}$ & $\$ 0.75$ & $\$ 5.50$ \\
\hline
\end{tabular}

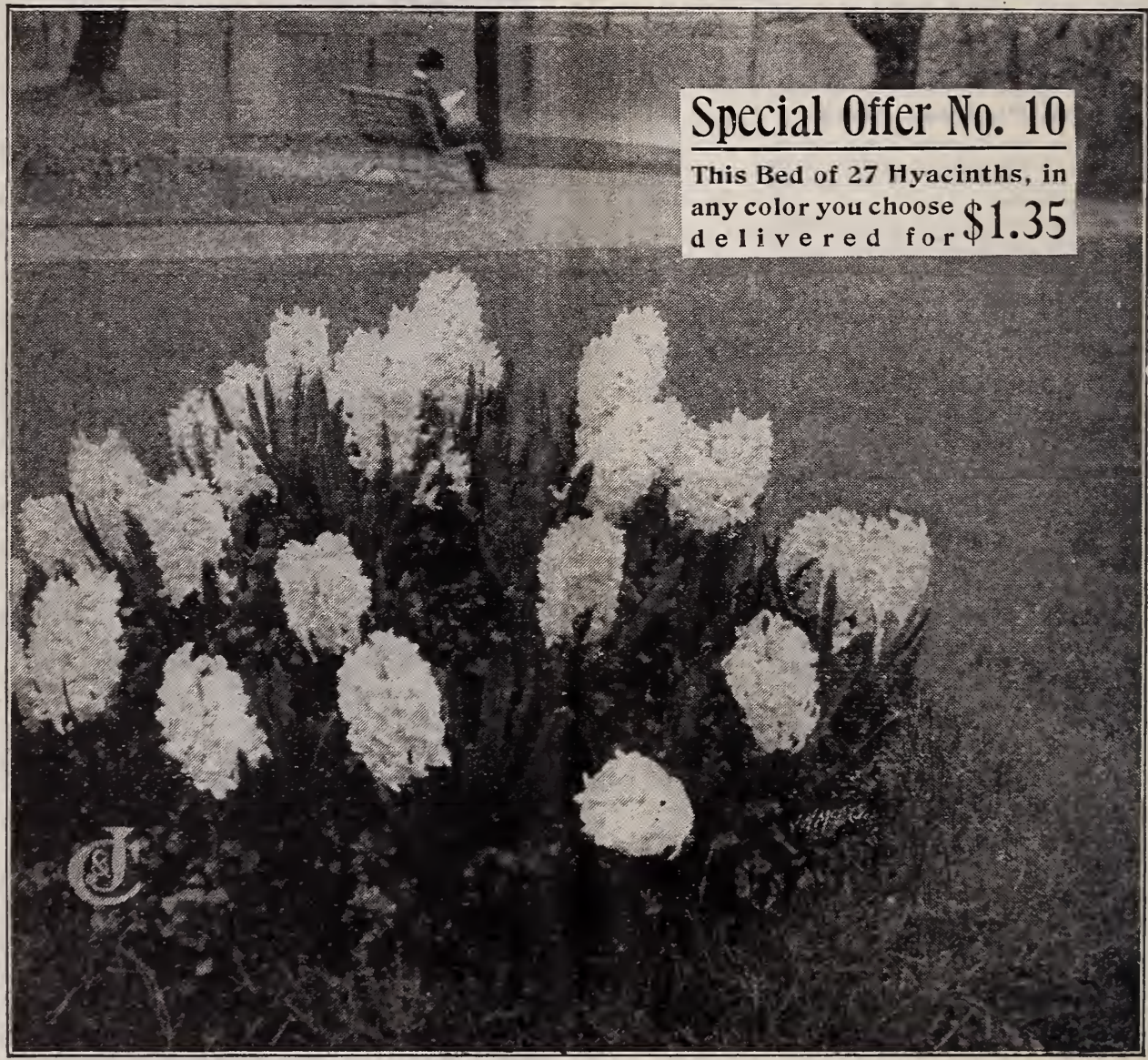

SEND US the size and shape And we will send you the right number of First Class Hyaonly 20c. per square foot.

NoTE-Plant Hyacinths about 6 inches apart each way (4 inches deep).

Avoid mixing colors-a solid row or several rows together all in one color will be found much more effective. We offer here some combinations that will make beautiful beds.

\section{Round Hyacinth Beds Price delivered}

No. 105 B-

No. $105 \mathrm{C}-5$

No. $10.5 \mathrm{D}-6$

No. $105 \mathrm{E}-7$

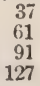

in U. S. A.

$\$ 1.10$

2.00
3.00

4.50

6.25

21.00

In ordering please state what color or colors you wish. The diagram of a round hed, on page 14, makes the planting very clear, but we will send you further suggestions if desired, and select and mark the right number of bulbs for any color combination you wish. of ANY BED on YOUR LAWN Square Hyacinth Beds ${ }^{\text {Price Delivered }}$ No. 106 A-Bed 3 ft. Square, 36 H y acinths, .... \$2.00 No. $106 \mathrm{~B}-$. 4 " $\quad$. 64

No. $106 \mathrm{C}-$

No. $106 \mathrm{D}-$
No. $106 \mathrm{E}-$

64
100
144 can lease state what colors you wish. Beautiful designs

\section{Hyacinth Beds}

$21 / 2$ feet wide (See lensth) Price Delivered No. 107 A - 3 ft. Long, 30 Bulbs, below

No. 107 B- 5 " 50

No. $107 \mathrm{C}-6$

No. $107 \mathrm{D}-8$

No. $107 \mathrm{E}-10$

No, $107 \mathrm{~F}-20$

50
80
100

9.50

and drives: 2 or 3 colors, in tong rows, will inake a effect. 


\section{Early Flowering Roman Hyacinths}

Roman Hyacinths are among the handsomest and most desirable of all Bulbs for early Winter flowering in the House or Conservatory. They begin to bloom very quickly and throw up great masses of sweet and lovely flowers almost before other bulbs get started. They are easily grown in pots or boxes; require no special treatment and are absolutely sure to bloom. Though recommended for House Culture they are quite hardy, and when planted in open ground will make an elegant display of lovely Howers very early in the Spring.

Prices: (All except Single Canary Yellow) PICCS 100. Delivered free in U. S. A.

Single Pure White-Early and profuse bloomer, very beautiful and sweet.

Single Blush White-Rich, creamy white, elegantly tinted with rosy blush; very beautiful, immense bloomer.

Single Light Blue $-A$ most charming color; early and profuse bloomer; rery sweet.

Double Pink-Splendid new rariety; beautiful large flowers, in handsome welleflled spikes.

single Canary Yellow-New aura very beautiful ; stock limited. 10c. each, 3 for $25 \mathrm{c} . ; \$ 1.00$ per doz., postpaid.

White Italian or Parisian Hyacinths-These bloom a little later than the Romans, and the flowers are larger; they are most abundant bloomers and delightfully sweet, highly valued for forcing, for cut flowers and for bedding out.

\section{SPECIAL OFFER No. 16}

Complete set of 5 named Roman Hyacinths, and one White Italian, offered above -6 in all - only $30 \mathrm{c}$., postpaid.

CONARD \& JONES Co.

Salem, Oregon, March 23, 1908.

Dear Sirs-The plants received in perfect condition. Let me tell you that no plants received have been as well packed, nor have reached me in as perfect a condition as those received from your me this year and for many years. Many thanks for your extras. Very truly,

$$
\text { Mrs. Ánnie Pennebaker. }
$$

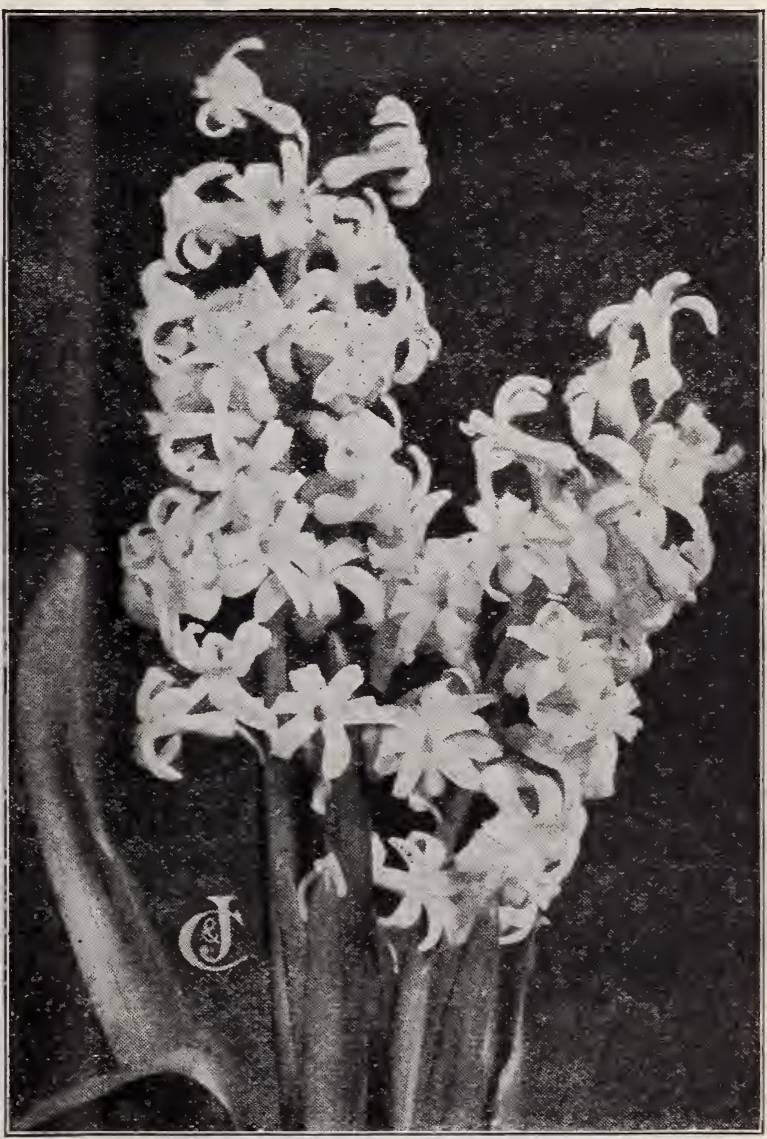

Roman Hyacinths

GRAPE AND FEATHERED HYACINTHS

Price Delivered

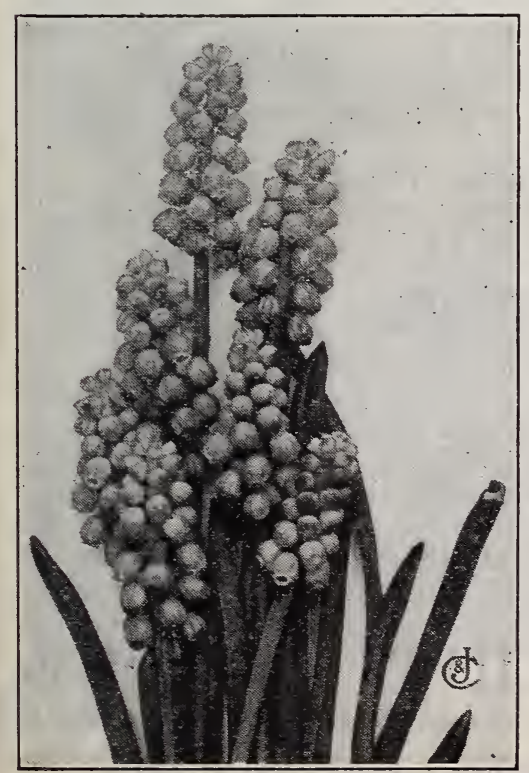

Grape Hyacinths

Blue Grape Hyacinths-Pretty spikes of lovely rich

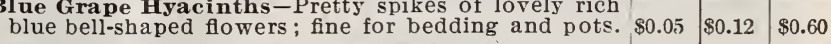
\begin{tabular}{|l|r|r|r} 
White Grape Hyacinths-A very scarce sort . . . . . & .10 & .20 & 1.00
\end{tabular}

Feathered Hyacinths-Lorely and curious little flowers, with feathery, plume-like spikes, deep blue tinged with red, fine for pot culture and bedding out also; hardy

\begin{tabular}{l|l|l}
.06 & .15 & 1.00
\end{tabular}

\section{MUSK HYACINTHS (Large Flowering)}

A charming dwarf-growing Hyacinth, rich purple and giving out a strong and very agreeable musky fragrance, valuable for pot culture and also for the flower bed. Entirely hardy. 3 for $10 \mathrm{c}$; 12 for $25 \mathrm{c}$.; $\$ 1.50$ per 100 , postpaid.

Special Offer No. 174 Blue Grape Hyacinths, 3 Snow Speclal Offer No. 17 White Grape Hyacinths, 2 Musk, 4 Feathered Hyacinths, 13 in all, postpaid, for $25 \mathrm{C}$.

\section{NEW MINIATURE OR POMPON HYACINTHS}

These charming little flowers re- Pure White, ) PRICE semble the Dutch Hyacinths, a re deliciously sweet scented and greatly admired for winter bloom indoors and for bedding out.

Rose Pink,

Red \& Crimson, Dark\& Light Blue, $\$ 3.00$ per 100 


\section{Single Early Tulips $\stackrel{\text { BEST NAMED }}{\ldots \text { VARIETIES }}$}

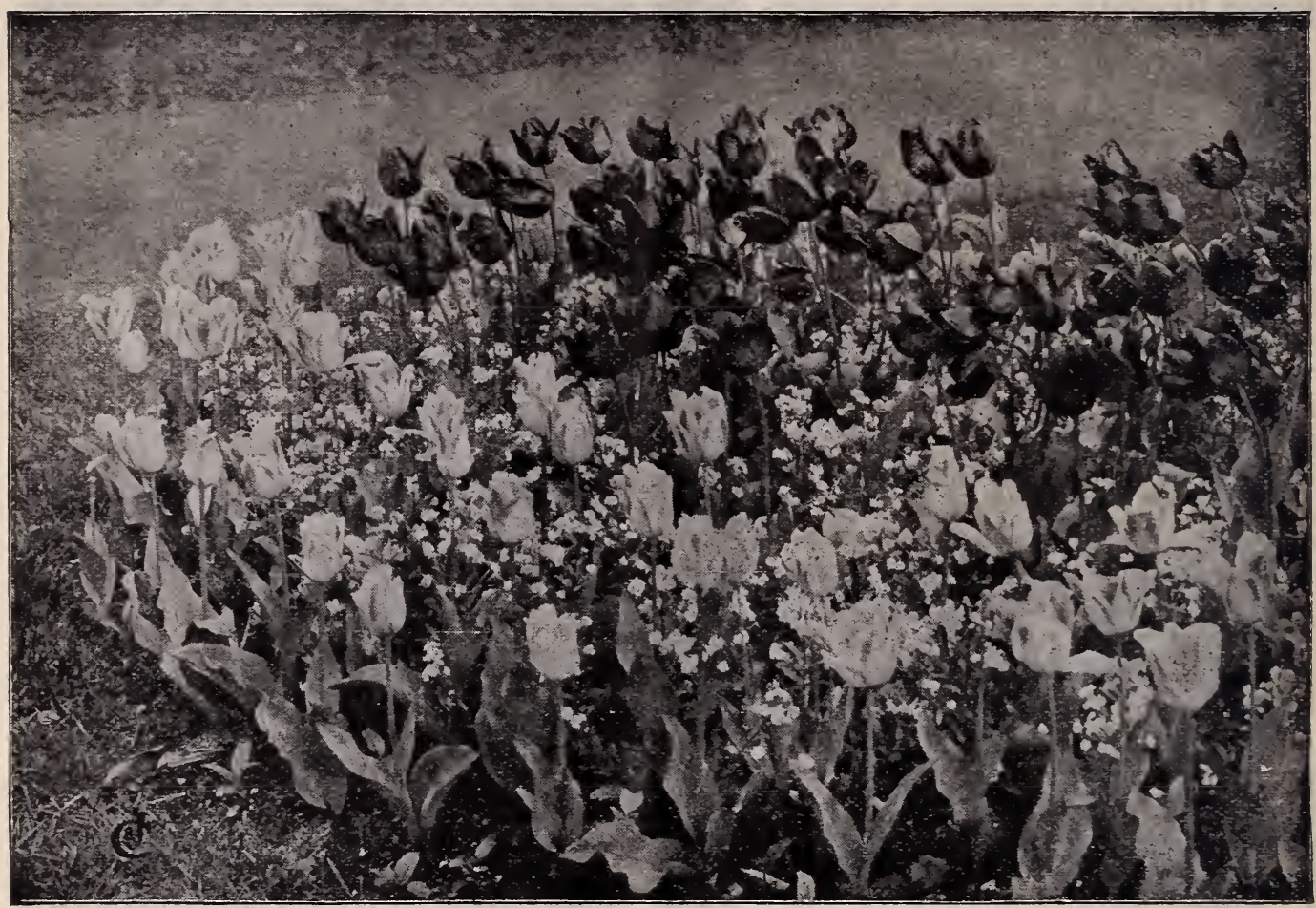

A Bed of Single Early Tulips-Named Varieties

Tulips are well known as the most showy and handsome of all Spring flowering bulbs. No other flowers can equal them in dazzling beauty; they are entirely hardy and do best when planted in open ground, and can always be depended on to throw up their splendid flowers early in the Spring. Our list includes the very best varieties for garden planting. The Figures $1,2,3$, etc., following the variety names, indicate their earliness of bloom. "The 1's
flower together and are the earliest of all, 2 's follow before the 1's are gone, etc. The height is indicated by " $D$ " for Dwarf, "II" for Medium height and "T" for Tall.

\section{\begin{tabular}{l|l} 
Prices delivered \\
\hline
\end{tabular}}

CRIMSON AND SCARLETS

Belle Alliance 3 M.-Beautiful rich scarlet, with yellow base,

Duc Van Thol Searlet 1 D. - Brilliant scarlet, largely used for forcing,

Proserpine 2 M.-Rich satiny rose. Extra large and fine.

Pottebaker Scarlet 2 M. - Bright crimson. Extra large and fine,

Vermilion Brilliant 3 M.-Dazzling scarlet. Very large and fine.

Wouverman 3 M. - Makes a magnificent flower of rich claret purple,

\section{WHITE}

Duc Van Thol White Maximus 1 I. - Pure white, popular early forcing variety

L'Inmaculee 3 M. - Large handsome flowers, white with yellow base,

Pottebaker White 2 M.-Large and fille,

SPECIAL OFFER No. 19_Set of 19 Tulips named above for $60 \mathrm{c} . ; 3$ of each, 57 in all, $\$ 1.50 ; 5$ of each, 95 in all, $\$ 2.40$, postpaid.
Prices delivered

free in U. S. A.
Each Doz. 100 \begin{tabular}{l|l} 
free in U. S. A. \\
Each Doz. 100
\end{tabular} $\$ 0.04 \$ 0.40 \$ 3.00$ \begin{tabular}{l|l|l|}
04 & .35 & 2.50
\end{tabular} \begin{tabular}{l|l|l}
.05 & .45 & 3.50
\end{tabular} \begin{tabular}{l|l|l}
.04 & .35 & 2.50
\end{tabular} \begin{tabular}{l|l|l}
05 & .45 & 3.50
\end{tabular} \begin{tabular}{l|r|r}
.04 & .40 & 3.00
\end{tabular} \begin{tabular}{l|l|l|l|}
\hline & & \\
& & \\
.04 & .35 & 2.50 \\
\hline & & & \\
\hline
\end{tabular} \begin{tabular}{l|l|l|}
.03 & .30 & 2.00
\end{tabular} Due Van Thol Car pink, dwarf, early flowering.

Cottage Maid 3 M.-Carmine pink, center of petals feathered white, with yellow base.

Joost Van Vondel 3 M. - Bright charming red, feathered with pure white,

\section{BLUSH PINKS}

Princess Marianna $\approx$ Mr. - Fine peach blossom pink, tinted yellow,

Queen Victoria 3 M. - Cream white, beautifully tinged with rosy blush,

\section{YELLOWS}

Chrysolora 3 M.-Beautiful pure yellow extrafine, Van Thol Yellow i i.-Bright yellow, early flowering,

Keizer Kroon 3 T.-Red, gold and yellow. (Sce Back Cover)

Pottebaker Yellow 2 M.-Pure yellow. Extra large and fine,

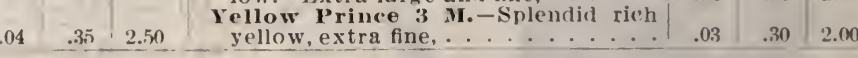

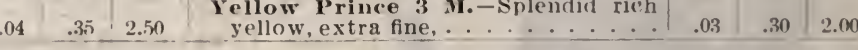
$\begin{array}{lll}\$ 0.04 & \$ 0.35 & \$ 2.50\end{array}$

\begin{tabular}{l|l|l}
.03 & .30 & 2.00
\end{tabular}

\begin{tabular}{l|l|l}
.03 & .30 & 2.00
\end{tabular}

\begin{tabular}{l|l|l}
03 & .30 & 2.00
\end{tabular}

\begin{tabular}{l|l|l}
03 & .30 & 2.00
\end{tabular}

\begin{tabular}{l|l|l|}
.03 & .30 & 2.00
\end{tabular}

\begin{tabular}{l|l|l}
.04 & .30 & 2.50
\end{tabular}

\begin{tabular}{l|l|l}
.04 & .35 & 2.50
\end{tabular}

\begin{tabular}{l|l|l|l}
.03 & .30 & 2.00
\end{tabular}

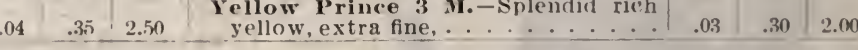

\section{C. \& J. SUPERFINE SINGLE MIXED TULIPS FOR BEDDING}

These are a suecial mixture made from choice named kinds. They grow same height and hloom at same time in the early Spring and make beds of dazzling beauty.

Price, 25c. per dox.; 1.35 per 100, delivered free; or 1.00 per ioo, \$9.00 per 1000 , by express, purchaser paying charges. For $\mathbf{T}$ ulips in separate colors, see pare 14. 


\section{Best Double Tulips ${ }_{\text {NAMED }}^{\text {.... varieties }}$}

The figures following the varieties indicate their earliness. Those marked " 1 " flower together and are the earliest. Those marked " 2 " follow, etc. The height is indicated by $D$. for dwarf, M. for medium and $T$. for tall. These are first-class bulbs and such as can be depended upon to produce fine large welldeveloped flowers of good substance and rich colors. These C. \& J.Bulbs are by test the Best.

\section{EARLY FLOWERING}

Crown of Roses 2 M.-Rich, rosy, carmine-Very large and double, 5ellow, broad gold margin,

La Candeur 3 M.-Pure white, extra large and full,

Murillo 2 M. - Blush white, shaded rose,

Rex Rubrorum 3 M.-Bright crimson scarlet. (See back cover),

Salvator Rosa 2 M. - Magnificent double, pink flamed, white,

Scarlet King 2 M.-Grand rich glowing crimson,

Tournesol Crimson 2 D.-Bordered yellow,

Tournesol Yellow 2 D. - B right golden yellow, shaded orange,
Duc Van Thol 1 D.-Double red and

Gloria Solis 2 M.-Deep crimson, with

\begin{tabular}{|r|r|r|}
\hline \multicolumn{3}{|c|}{$\begin{array}{l}\text { Prices delivered } \\
\text { free in U. S. A. }\end{array}$} \\
\hline Each & Doz. & 100 \\
\hline$\$ 0.06$ & $\$ 0.60$ & $\$ 4.50$ \\
.03 & .25 & 1.75 \\
.04 & .35 & 2.50 \\
.03 & .30 & 2.00 \\
.04 & .40 & 3.50 \\
.04 & .35 & 2.50 \\
.06 & .60 & 4.50 \\
.03 & .35 & 2.50 \\
.01 & .35 & 2.25 \\
.05 & .50 & 4.00 \\
\hline
\end{tabular}

SPECIAL OFFER No. 20

10 Double Early Tulips; postpaid, for $35 \mathrm{c}$.; 3 of each, 30 in all, for $90 \mathrm{c}$; 5 of each, 50 in all, for $\$ 1.60$, postpaid.

\section{LATE FLOWERING}

Prices delivered free in U. S. A.

Each Doz. 100

Admiral Kingsbergen 4-Red and

yellow, very handsome, ..... $\$ 0.04 \$ 0.35 \$ 2.50$

Belle Alliance 4-Blue and white, extra fine, ................

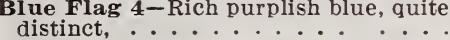

Count of Leicester 4 -Rich crimson and $w$ hite,

Duke of York 4 M. - Bright rose, bordęred white,

Marriage de ma Fille 4-Pure white, feathered with rich crimson,

Peony Gold 4-Rich crimson and golden yellow, magnificent double,

Peony Red 4-Resembles a grand blood-red rose, extra fine,

Violet Picotee 4 (Blanche Borde Po u r p e ) - Violet, bordered and tinted with white,

Yellow Rose 4-Pure yellow, the true yellow rose,

\begin{tabular}{l|l|l}
.04 & .35 & 2.50
\end{tabular}

\begin{tabular}{l|l|l}
$.04 \quad: 35$ & 2.50
\end{tabular}

\begin{tabular}{l|l|l}
03 & .25 & 1.75
\end{tabular}

\begin{tabular}{l|l|l}
.03 & .25 & 1.75
\end{tabular}

$\begin{array}{llll}04 & .30 & 2.00\end{array}$

\begin{tabular}{l|l|l}
.04 & .35 & 2.50
\end{tabular}

$\begin{array}{lll}03 & .30 & 2.00\end{array}$

\begin{tabular}{l|l|l}
03 & .25 & 2.25
\end{tabular}

\begin{tabular}{l|l|l}
.04 & .25 & 1.75
\end{tabular}

SPECIAL OFFER No. 21

10 Double Late Tulips, 30c., postpaid; 2 of each, 20 in all, for $50 \mathrm{c}$; 5 of each, 50 in all, for $\$ 1.40$, postpaid.

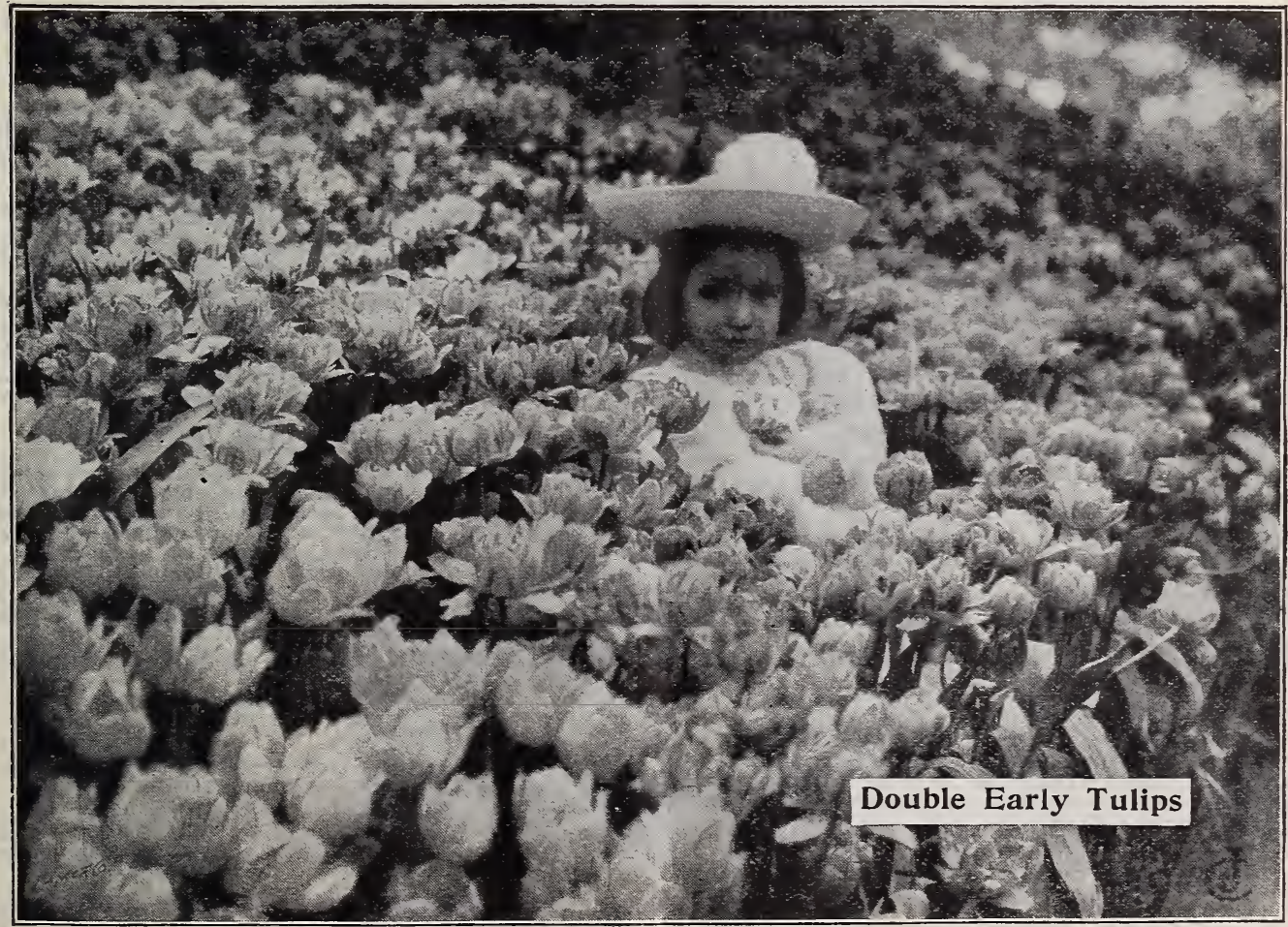

DOUBLE FARIY TULIPS Best varieties mixed. Price, 4 for 10c.; 25c. per $\$ 10.00$ per 1000 , by express, purchaser paying charges. 


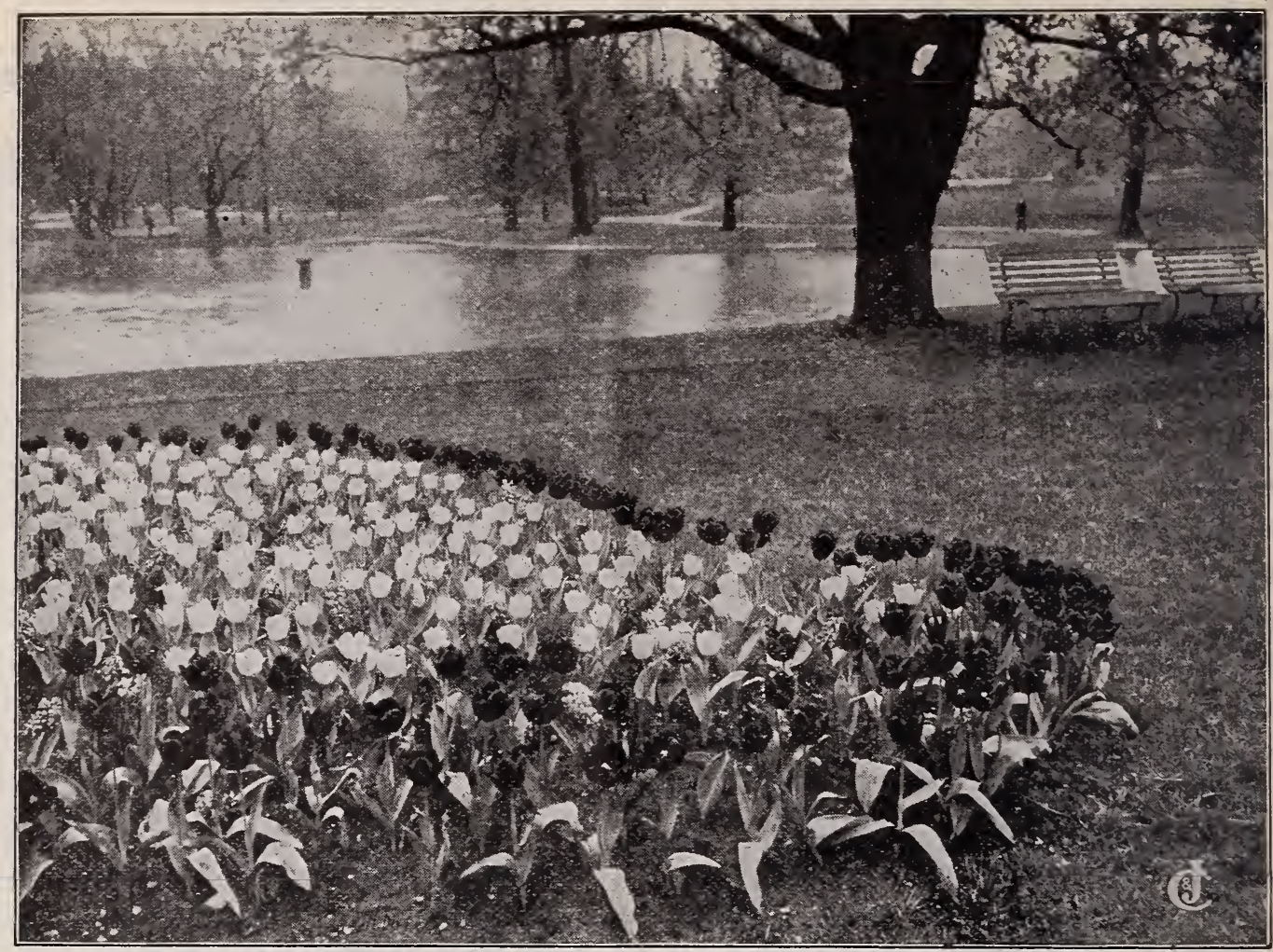

A Bed of Choice May Flowering Tulips.

\section{Late May Flowering Tulips}

These Tulips are quite distinct from the early flowering kinds-coming later they extend the blooming season two to three weeks longer, and are usually at their best about Decoration Day. They are all single. They are extremely hardy and therefore excellent for planting in the herbaceous border, among the shrubbery or for naturalizing in any place where they can remain undisturbed and bloom regularly for years. Splendid for bouquets because of their durable flowers and long stems. Set these bulbs 4 inches deep.

\section{COTTAGE GARDEN TULIPS}

Bouton d'Or-Deep rich golden yellow, handsome globeshaped flowers, exceedingly beautiful. 4c. each; $35 \mathrm{c}$. per doz.; $\$ 2.50$ per 100 , postpaid.

Bridesmaid-Bright rich scarlet, striped pure white. Very distinct and beautiful. 4c. each; 40c. per doz.; $\$ 3.00$ per 100 , postpaid.

Elegans - Very grand and showy, rich crimson scarlet, large handsome flowers. 4c. each; 40c. per doz.; $\$ 3.00$ per 100 , postpaid.

Golden Eagle-Extra large and handsome, rich orange yellow flowers, each petal edged with bright crimson, very showy. 3c. each; 30c. per doz.; $\$ 2.00$ per 100 , postpaid.

May Blossom-Pure white, elegantly striped and variegated with red, finely formed, and a most charming valiety. 4c. each ; 45c. per doz.; $\$ 3.00$ per 100 , postpaid White Swan-A splendid pure white tulip, extra large flowers, with broad silky white petals. Very handsome. 3c. cach ; 30c. per doz.; $\$ 2.00$ per 100 , postpaid.

SPECIAL OFFER No. 22-Set of 6 Charming Garden Tulips only 20c., postpaid

\section{VARIEGATED FOLIAGE TULIPS}

Leaves of the plant are distinctly marked and striped with white, and flowers large and beautiful. Price, $4 \mathrm{c}$ each ; 3 for 10c.; 35c. per doz., postpaid.

Lac Van Rhijn-Violet red bordered with pure white. Purple Crown-Bold striking flow's of dark purplish red. Silver Standard-Pure white crossed with rich crimson. SPECIAL OFFER No. 23-These 3 for $10 \mathrm{c}$. , or 4 Sets, 35c., postpaid

\section{LOVELY PICOTEE TULIPS}

Quaintly fashioned flowers with sharply pointed petals that curve out, giving the cup of each blossom a spreading star shaped rim. The petals a re prettily colored and the entire effect of the Picotee is particularly pleasing. Price, 5c. each ; 40c. per doz.; $\$ 3.00$ per 100, postpaid.

Picotee, White-Waxy white with fcathered crimson border.

Picotee, Yellow-Deep golden yellow, red feathered edge. Picotee, Red-Rich scarlet elegantly shaded.

SPECIAL OFFER No. 24-3 Lovely Picotee Tulips, $12 \mathrm{c}$.

\section{Sweet $=$ Scented Tulips}

We recommend our friends to try these lovely New Sweet-scented Tulips-they are extra fine for housc and conservatory culture, and also for bedding out-they grow easily and never fail to bloom, and the flowers are very rich and handsome and deliciously fragrant.

Golden Pearl (Newton)-The sweetest of all sweetscented tulips; has the delicious tea fragrance of the American Beauty Rose, lovely golden yellow blossoms, blooms very early, and very fragrant, one of the best. 5c. each; 50c. per doz.

Prince of Austria-Grand flowers of largest size, thick glossy petals, rich orange scarlet, delightfully sweetscented. 5c. each; 50c. per doz., postpaid.

Florentine Odorata-(The Tea Rose Tulip)-Rich yellow flowers, beautiful buds, very sweet. 5c. each; 40c. per doz., postpaid.

Macrospila-Brilliant citron red, with dark clouded centre, finely bordered with bright golden yellow, very large and handsome. 5c. each; 40c. per doz., post-
paid

SPECIAL OFFER No. 25 - The Set of 4 Sweet-Scented Tulips for $15 \mathrm{c}$. 


\section{Giant Gesneriana}

\section{Tulip, Crimson}

The True Giant Gesneriana is one of the grallest and most beautiful of all Tulips; they grow $1 \frac{1}{2}$ to 2 feet high and bear great rich blooms as large as teacups. Color intense fiery scarlet, with bright shining blue-black cen. ter. The flowers are very durable and keep their splendid colors for several weeks. They are entirely hardy and will bloom on from year to year. We recommend all to try a bed of our True Gesneriana Tulips; their wonderful beauty is truly marvelous. (See cut No.1.) मी

Price, 3c. each; 35c. per doz.; $\$ 2.50$ per 100, delivered free. By express, $\$ 2.00$ per 100 , buyer paying charges.

\section{Gesneriana, Yellow}

\section{or Golden Crown Tulip}

Splendid large bold flowers, bright rich golden yellow, beautifully fringed with orange red.

Price, 3c. each; 35c. per doz.; $\$ 2.50$ per 100, delivered free.

\section{Gesneriana, White} (Sweet Nancy)

(Alba Marginata.) A very lovely variety, pure white edged with rose.

Price, 3c. each; 3 for 8c.; 30c. pe doz.; $\$ 2.00$ per 100 . Delivered free.

\section{Darwin Tulips}

The Darwin Tulips are a magnificent new class of large May-flowering Tulips, just recently introduced. They grow 18 inches to two feet high, and bear splendid flowers of immense size and most brilliant colors, including gorgeous shades of blue, crimson, rose, yellow, purple, brown and coal black, far surpassing everything before known in Tulips. They are entirely out of the usual. Plant six inches apart and five inches deep, in the open ground.

Price, all colors mixed, $4 c$. each: 40c. per doz.; $\$ 3.00$ per 100. Delivered free.

\section{SPECIAL OFFER No. 36 \\ 1 Giant Gesneriana, bright scarlet. \\ 1 Swe et Nancy, pure white. \\ 1 Ye 110 wesneriana, Rich golden yellow fringed with red. \\ 1 Darwin, selected from mixed colors. \\ The 4 varieties, $12 C$ only}

Parrot or Dragon Tulips

These belong to the late or May Flowering Tulips; the flowers are very large, frequently six or seven inches across, with petals deeply toothed, fringed and twisted in the most striking and fantastic manner, sometimes representing the head and beak of a parrot. The colors are exceedingly brilliant and showy. They grow about 10 inches high. (See cut No.4.)

OFFER No. 37-Set of Seven Par=

rot Tulips, postpaid, for $25 \mathrm{c}$.

BELLE JA UNE-Pure deep yellow.

CAFE BRUN-Coffee color and yellow. CONSTANTINOPLE-Deep blood red. FEU BRILLANTE-Rich satiny crimson. MARK GRAAF-Crimson and orange, very handsome.

ORANGE (Gloriosa)-O r ạnge and crimson.

PERFECTA-Red and yellow. extra fine.

Price, any of the above-named Parrot Tulips, 4c. each; 40c. per doz.; $\$ 3.00$ per 100 . Delivered free in U. S. A.

MIXED PARROT TULIPSPrice, 4c. each; 35c. per doz.; $\$ 2.25$ per 100 , delivered free.

\section{Queen of Tulips}

(Tulipa Greigii)

Large handsome foliage, curiously spotted with dark maroon. Many brilliant colors. $12 \mathrm{c}$ e a ch $\$ 1.25$ per dozen.

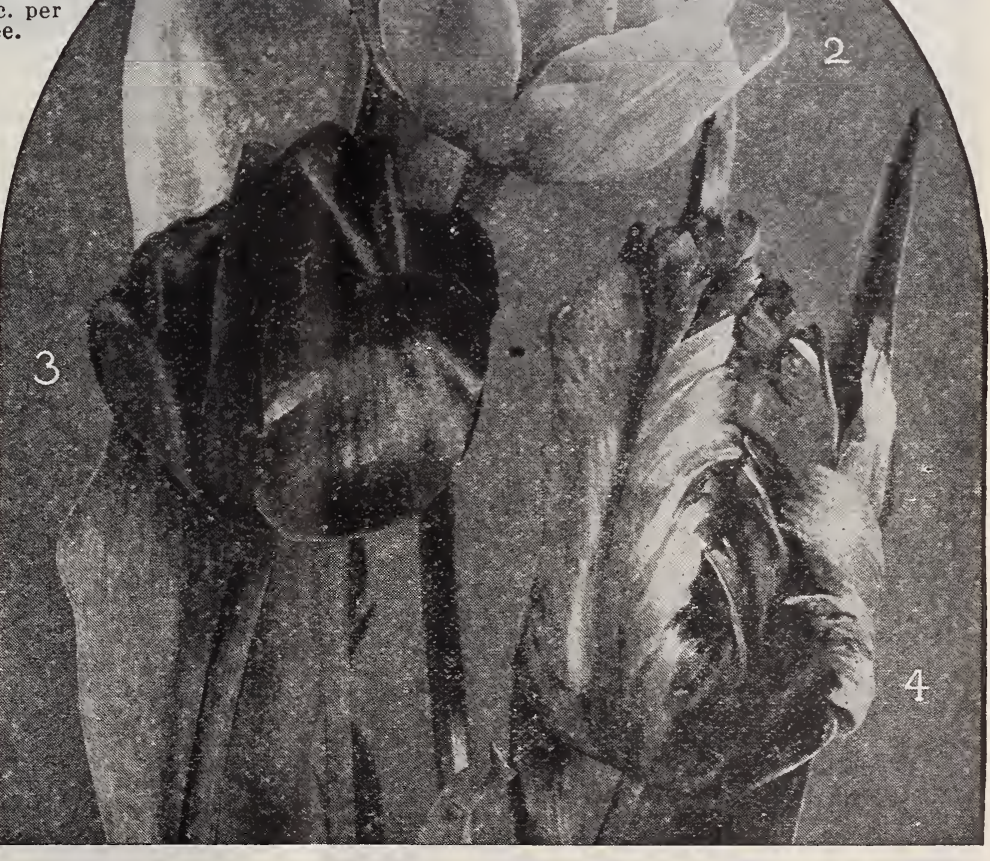

More Interesting Still Are the BIZARRE TULIPS

These are greatly admired for their brilliant and striking colors - their large what resemble the Gesneriana; are mostly yellow grounds flamed and blazed with maroon, black, scarlet etc. Price, mixed colors, $4 \mathrm{c}$. each; 30c. per doz.; $\$ 2.00$ per 100 , delivered free.

\section{BYBLOEMEN TULIPS}

Unusual color combinations, feathered, flaked and wonderfully variegated. Two distinct kinds. as follows:

VIOLET BYBLOEMEN \} Price, 4c. each; 35c. per

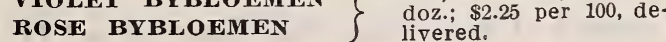




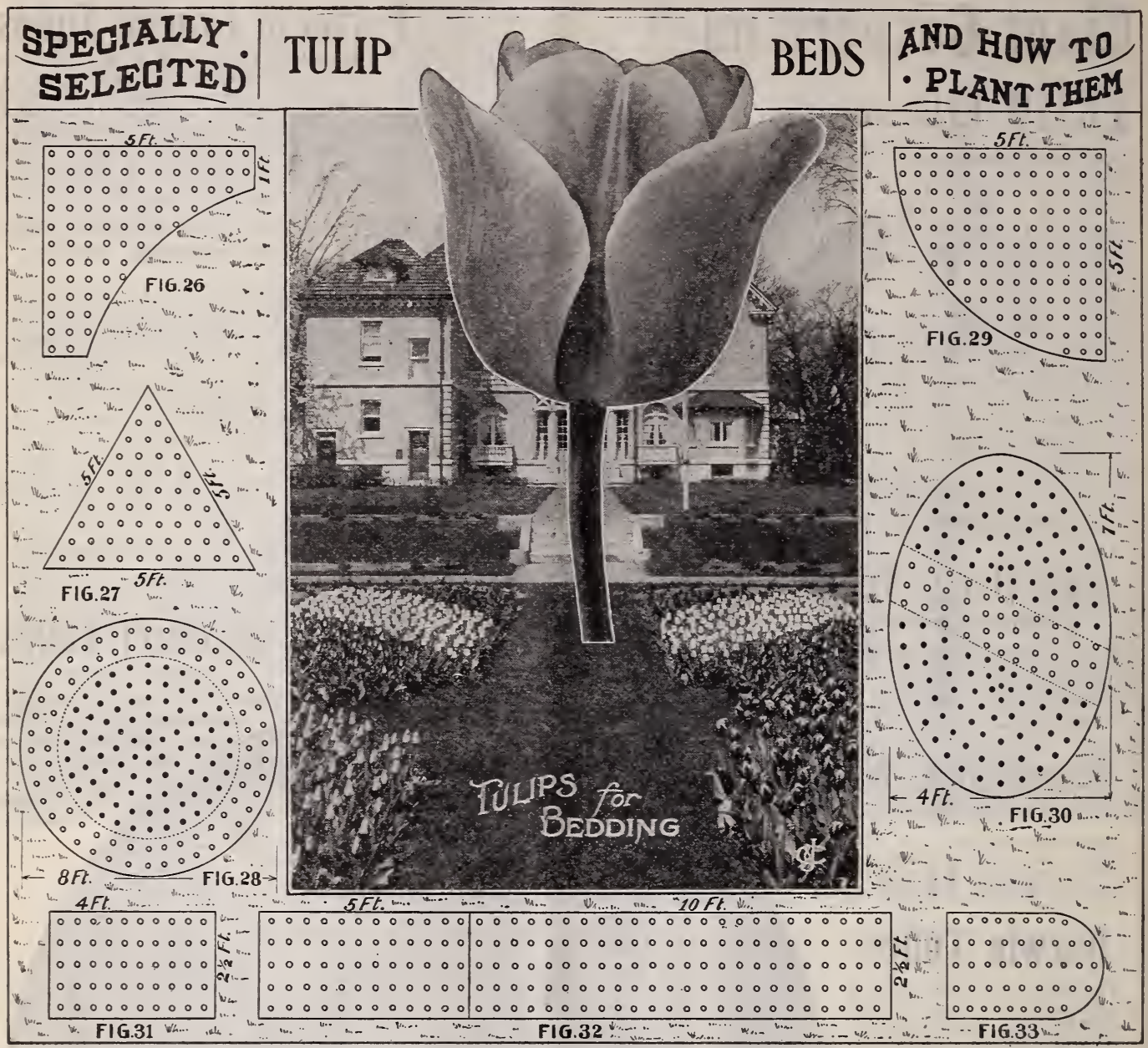

Above diagrams will suggest a variety of plans that can be followed in laying out Tulip Beds. We adrise planting in solid colors unless otherwise noted ( 5 inches a part and 4 inches deep). When ordering please state whether you wish White, Crimson, Pink, Yellow or Variegated, and whether Single or Double.

\section{Tulips Required to Fill above Beds}

Bed No. 26- S0 Tulips, in any color you wish, price, $\$ 1.40$

$$
\begin{aligned}
& 27-55 \\
& 28-169 \\
& 29-120 \\
& 30-160 \\
& 31-50 \\
& 32-180 \\
& 33-46
\end{aligned}
$$

\section{Prices of Tulips in Separate Colors}

Especially selected to grow to same height and bloom at the same time.

Prices delivered free in U. S. A.

\begin{tabular}{r|r}
100 & 1000 \\
\hline$\$ 1.75$ & $\$ 14.00$ \\
1.75 & 14.00 \\
1.75 & 14.00 \\
1.75 & 14.00 \\
1.75 & 14.00 \\
1.35 & 10.00 \\
1.35 & 9.00 \\
\hline
\end{tabular}

double.

It is easy to make up a bed of your own

\begin{tabular}{|c|c|c|}
\hline S & 100 & 100 \\
\hline $\begin{array}{c}\text { Belle Alliance } \\
\text { base }\end{array}$ & $\$ 3.00$ & $\$ 24.6$ \\
\hline Pottebake & & \\
\hline $\begin{array}{c}\text { Vermilion Brilliant } 3 \text { M. }- \text { Bright scarlet, } \\
\text { Single White }\end{array}$ & 3.50 & 28 \\
\hline L'Immacule & 00 & 15. \\
\hline $\begin{array}{l}\text { d fine, } \\
\text { beau- }\end{array}$ & 2.50 & \\
\hline tifully tin & 2.00 & 5.00 \\
\hline Chr & 0 & 5.00 \\
\hline & & \\
\hline Yellow & 2. & \\
\hline $\begin{array}{l}\text { Keizer } \\
\text { (see } \\
\text { Joost }\end{array}$ & 50 & $0 .(\mathrm{C}$ \\
\hline & & \\
\hline Wouverman & 0 & \\
\hline & & \\
\hline & & \\
\hline
\end{tabular}
Try it
The FINEST NAMED TULIPS for BEDDING-Especially Recommended Prices Delivered in U. S. A. 


\section{Narcissus or Daffodils}

The Narcissus or Daffodils are among the earliest to bloom and most brilliant and showy of all our Spring flowers. They are entirely hardy and highly valued for beds and borders in yard and garden, and also for Winter blooming in the house. When potted, they flower very quickly and will soon fill your window garden with beauty and fragrance. For the flower beds set 3 or 4 inches deep and 4 to 6 inches apart, according to the size of the bulb. They bloom beautifully very early in the Spring; the flowers are very rich and handsome and delightfully sweet. They are very different in form and color, but all exceedingly beautiful.

\section{TRUMPET NARCISSUS}

Glory of Leiden-(See Illustration.) You nave doubtless heard of the famous old city of Leiden in Belgium, where it is believed this glorious Daffodil originated, and is still cultivated in great perfection. It is a magnificent new sort, with immense flowers of great substance and beauty; large, long, fluted trumpets ; deep, rich, golden yellow, and borne on broad sturdy stems with thick leathery foliage; a healthy vigorous grower and early and profuse bloomer; being new and scarce the price is necessarily high,

Emperor-Next to Glory of Leiden, this is one of the grandest of all Daffodils; flowers of the very largest size. Clear rich golden yellow, with immense fluted trumpet, and petals so large as to overlap, and flowers measure $3 \frac{1}{2}$ inches across. Very sweet and a real treasure of beauty and fragrance; will last for days when cut, and perfume the whole house; entirely hardy and an early and abundant bloomer.

Fmpress "White Wings" - A magnificent variety; large bold flowers, borne erect and considered the finest of the two-colored trumpets, Grandee - Flowers extra large with broad creamy white petals and magnificent golden yellow trumpets, beautifully crimped and ruffled. exceedingly handsome,

Golden Spur - This is one of the grandest of Daffodils, extra large, bold rich yellow flowers and broad handsome foliage. A strong grower and early bloomer, unsurpassed for garden or house culture,

Princeps-Very early and one of the most popular Winter-flowering rarieties; soft sulphur yellow, with immense deep yellow trumpets,

Sir Watkin-The Giant Chalice Flower, or Big Welshman. One of the largest Daffodils grown; immense long-stemmed flowers, sometimes $5 \frac{1}{3}$ inches across ; rich lemon y ellow, large dark cup tinted with orange; grand and handsome,

Trumpet Major-Bright golden yellow, one of the best for bedding and fine Winter flowering; an early and abundant bloomer,

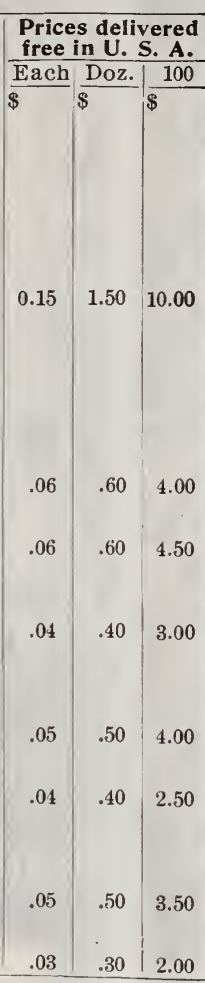

SPECIAL OFFER No. 38-Set of 8 Splendid Trumpet Narcissus, only 40c. Postpaid.

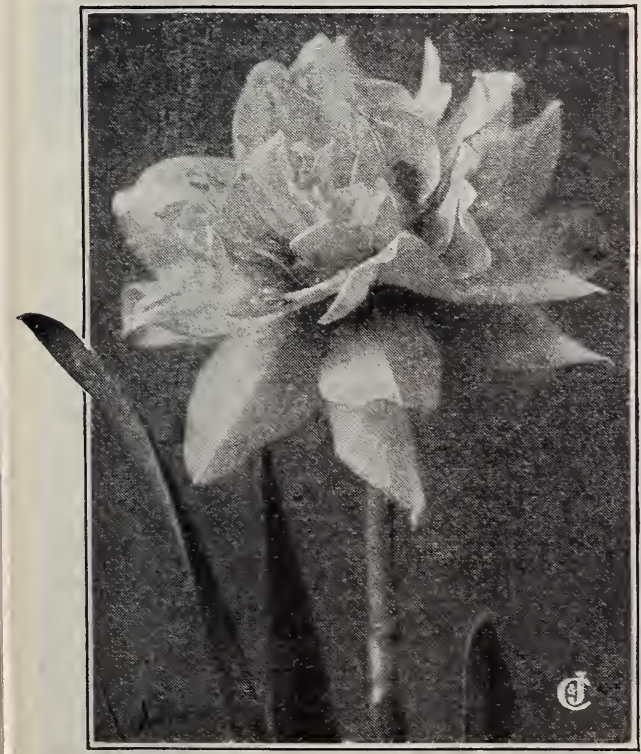

Double Daffodil-"Von Sion"

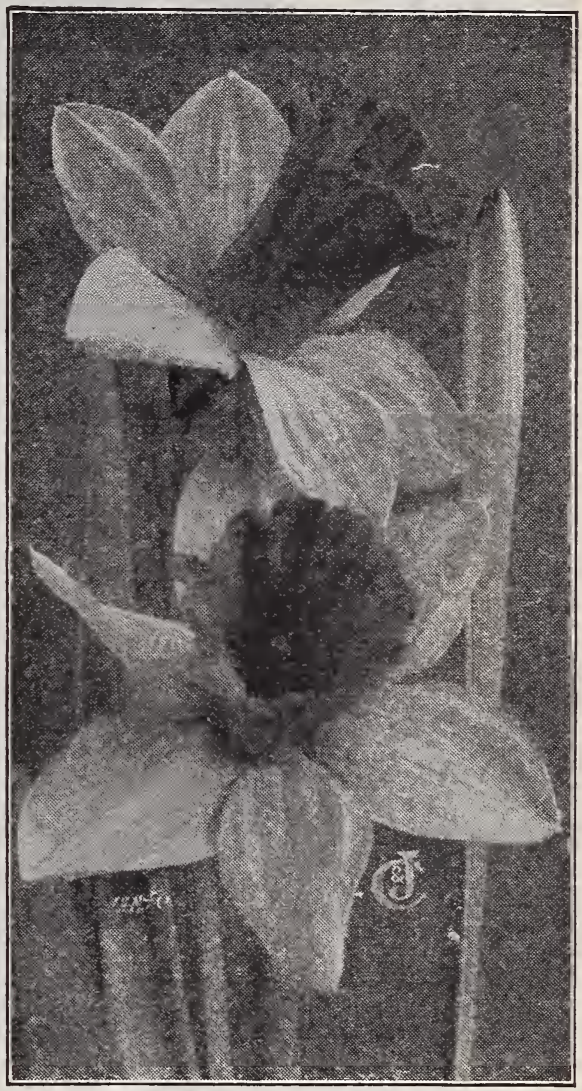

"Fair Yellow Daffodils-

stately and tall,

DOUBLE NARCISSUS

\section{OR IMPROVED DAFFODILS}

\begin{tabular}{|c|c|c|c|}
\hline \multirow{4}{*}{$\begin{array}{l}\text { Alba Plena Odorata - "The Double } \\
\text { White Poet's Narcissus," or Gardenia- } \\
\text { Flowered Daffodil. Double snow-white } \\
\text { gardenia-like flowers, delightfully sweet- } \\
\text { scented. }\end{array}$} & \multicolumn{3}{|c|}{$\begin{array}{l}\text { Prices delivered } \\
\text { free in U. S. A. }\end{array}$} \\
\hline & Each & Doz. & 100 \\
\hline & & & \\
\hline & $\$ 0.03$ & $\$ 0.25$ & $\$ 1.50$ \\
\hline Incomparable - Fl. $\mathrm{Pl}$ "Butter and & & & \\
\hline Eggs." Large handsome flowers, as & & & \\
\hline $\begin{array}{l}\text { double as roses, bright canary yellow, } \\
\text { with rich orange center, }\end{array}$ & .04 & .35 & 2.25 \\
\hline Orange Phoenix - "Eggs and Bacon." & & & \\
\hline $\begin{array}{l}\text { Outer petals nearly pure white, center } \\
\text { mixed orange and white, very handsome, }\end{array}$ & .04 & .40 & 2.50 \\
\hline Sulphur or Silver Phoenix - "Codlins & & & \\
\hline and Cream." Creamy white with pale & & & \\
\hline $\begin{array}{l}\text { sulphur center, often considered the fin- } \\
\text { est of the double sorts, }\end{array}$ & .07 & .75 & 5.00 \\
\hline Von Sion-The true Double Yellow Daf- & & & \\
\hline $\begin{array}{l}\text { fodil. A famous old kind, unsurpassed } \\
\text { in beauty, single outside petals with long }\end{array}$ & & & \\
\hline $\begin{array}{l}\text { double trumpet, filled with beautifully } \\
\text { crimped petals, extra fine for cutting,. }\end{array}$ & .04 & .40 & 2.50 \\
\hline
\end{tabular}

SET No. 39-The Five Varieties for $18 \mathrm{c}$. 


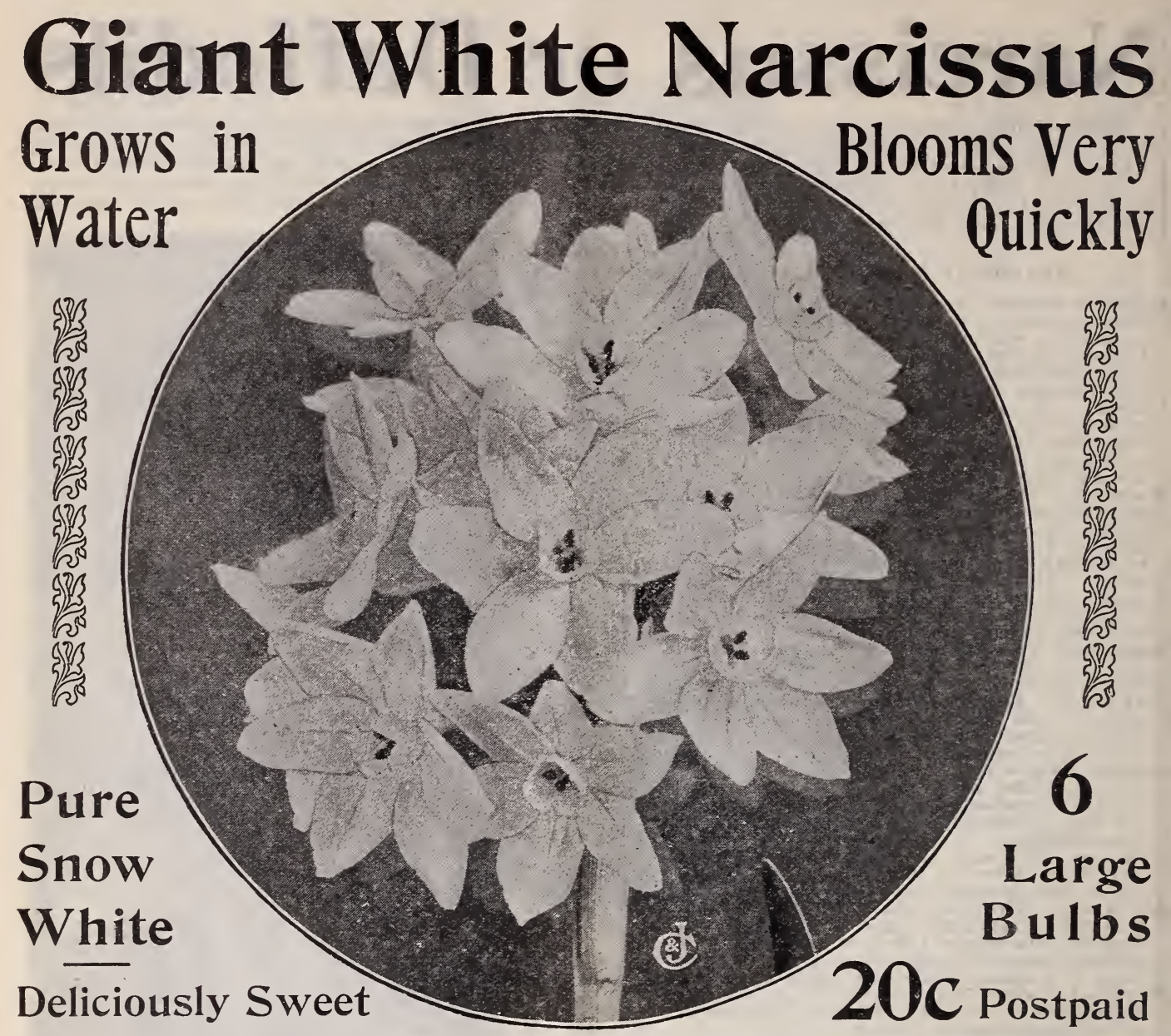

THE TRUE PAPER WHITE GRANDIFLORA or Large Flowering Polyanthus Narcissus will grow in water and produce great masses of snow-white, fragrant flowers, a few weeks after planting. Splendid for house and church decorations. We recommend all our friends to plant these lovely Winter-blooming Narcissus. No other bulbs we know of will produce such an abundance of pure white sweet-scented flowers with so little trouble. A dozen bulbs, set in a bowl of water and held in place by pebbles, will make a charming pot of flowers for house or church decoration, and can be had at any time desired. The bulbs will keep in any warm, dry place till wanted, and by planting at different times, you can have a succession of lovely flowers all Winter.

FIRST CLASS BULBS, $5 \mathrm{c}$. each, 6 for $20 \mathrm{c}$., $35 \mathrm{c}$. per dozen, $\$ 2.50$ per 100 , delivered free; $\$ 18.00$ per thousand, buyer paying charges.

\section{DOUBLE ROMAN NARCISSUS}

This is one of our very finest Winter-flowering varieties. The flowers are perfectly double and pure snow-white, with small center petals of rich golden yellow. It blooms very quickly either in water or soil, and is delightfully fragrant. Its quick bloom and wonderful profusion of flowers is truly surprising; vast quantities are grown every season for floral decorations; also fine for the open ground. Strong blooming bulbs, 4c. each, 35c. per doz., $\$ 2.50$ per 100, delivered.

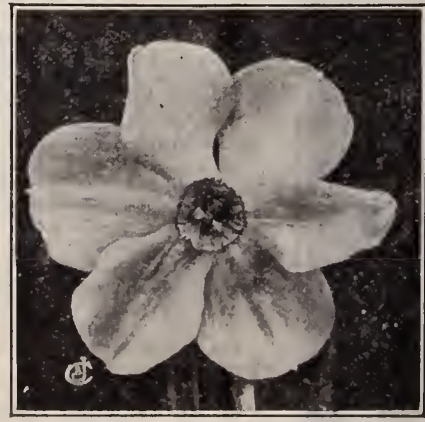

A Poets Narcissus

One of the finest Narcissus for Winter bloom; pure waxy-white flowers with crimson-bordered cups; blooms very quickly either in water or soil. 3c. each, 25c. per doz., $\$ 1.50$ per 100 , delivered free.

\section{Narcissus Poeticus}

"The Pheasant's Eye." Pure white star-like flowers with orange cup edged with crimson; hardy and fine for bedding, splendid for cut flowers. 3c. each, 20c. per doz., 75c. per 100, postpaid. 


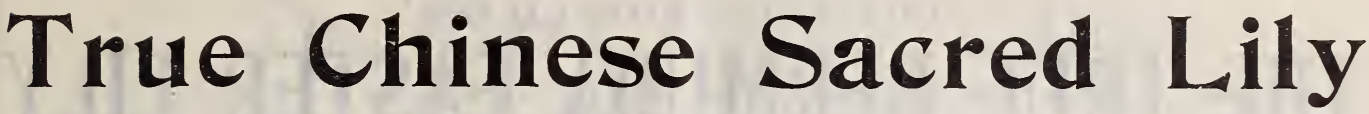
THE WATER FAIRY FLOWER OR “SHIN SIN FAR"-OR CHINESE “JOSS FLOWER"

The Great Chinese Sacred Lily is still one of the most popular Winter-blooming bulbs we have. They grow very easily and are sure to bloom quickly; they like moderate moisture and plenty of light and heat. They grow nicely in pots of ordinary soil, but the easiest and quickest way to bloom them is in a bowl of water with a few pebbles to hold the bulbs in place. The bulbs are large, and each one sends up from five to twelve flower stems bearing great clusters of large pure white wax-like blossoms, with yellow centres and deliciously fragrant. Some are single and others double, but all equally beautiful, and they bloom so quickly and abundantly they are in great demand everywhere. They continue to bloom a long time, and by planting at different times, a few weeks apart, you can have flowers all Winter and Spring. Ours are the Genuine Chinese Sacred Lily grown in China.

Price, first size quick-blooming bulbs, 12c. each ; 3 for $35 \mathrm{c}$.; $\$ 1.25$ per doz. Original baskets containing 30 bulbs, $\$ 2.75$; or $\$ 9.00$ per 100 , delivered free in U. S. A. Or by express, purchasers paying charges, basket of 30 for $\$ 2.00$, or $\$ 6.50$ per 100 .

\section{Golden Sweet=Scented Sacred Lily (Campernelle Rugulosus)}

Clear, bright golden yellow flowers, very fragrant. Of the same family as the Chinese Sacred, but larger.

One dozen bulbs in a bowl of water will make an elegant display of flowers in a very short time, and when planted in the garden will bloom almost as early as the crocus.

Price, 3c. each ; 4 for 10c.; 25c. per doz.; $\$ 1.50$ per 100 , delivered free.
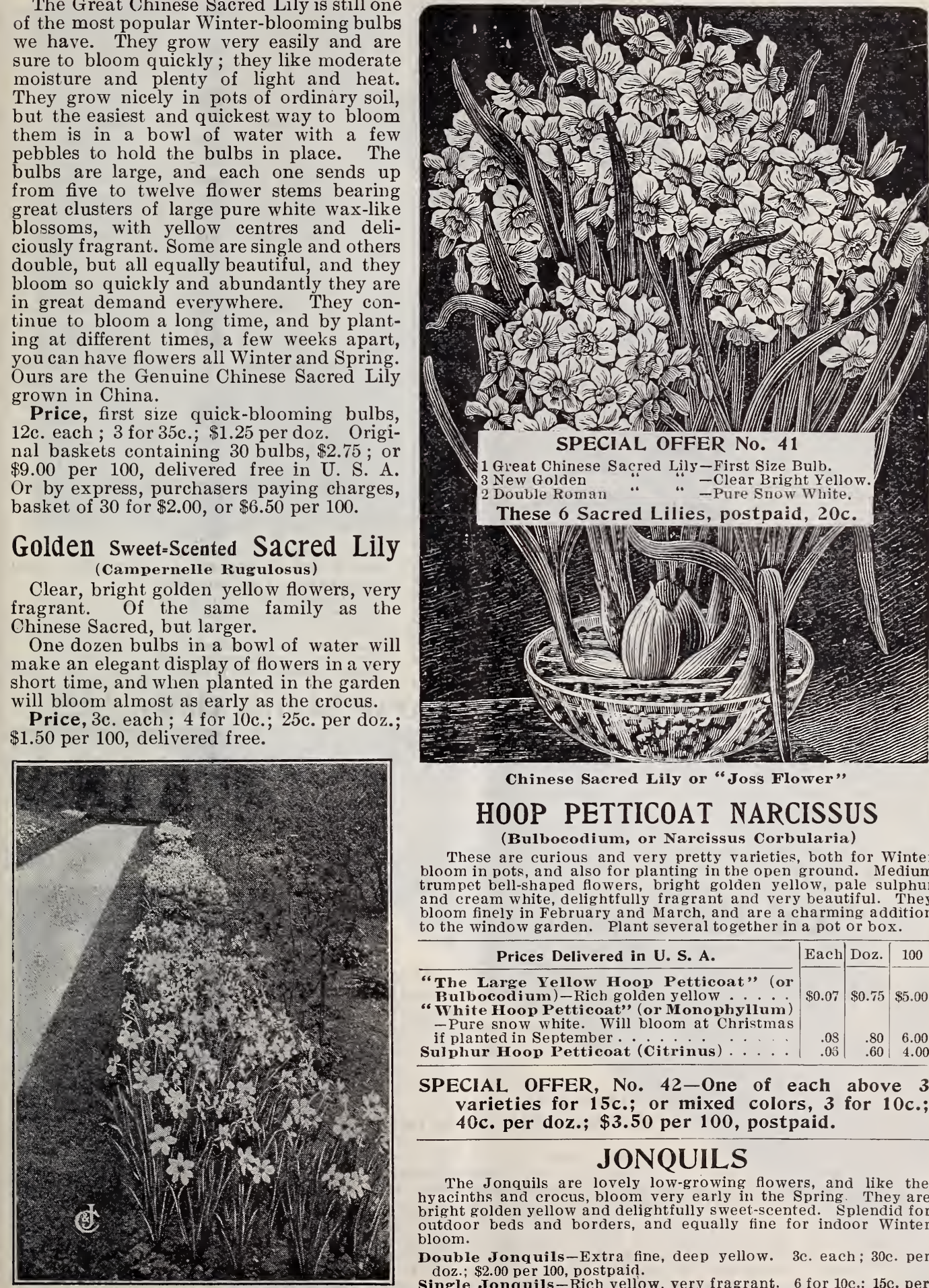

Chinese Sacred Lily or "Joss Flower"

\section{HOOP PETTICOAT NARCISSUS}

(Bulbocodium, or Narcissus Corbularia)

These are curious and very pretty varieties, both for Winter bloom in pots, and also for planting in the open ground. Medium trumpet bell-shaped flowers, bright golden yellow, pale sulphur and cream white, delightfully fragrant and very beautiful. They bloom finely in February and March, and are a charming addition to the window garden. Plant several together in a pot or box.

\begin{tabular}{|c|c|c|c|}
\hline Prices Delivered in U. S. A. & Each & Doz. & 100 \\
\hline $\begin{array}{l}\text { "The Large Yellow Hoop Petticoat" (or } \\
\text { Bulbocodium)-Rich golden yellow . P . } \\
\text { " White Hoop Petticoat" (or Monophylium) } \\
\text {-Pure snow white. Will bloom at Christmas }\end{array}$ & $\$ 0.07$ & $\$ 0.75$ & \\
\hline $\begin{array}{l}\text { if planted in September } \\
\text { Sulphur Hoop Petticoat (Citrinus) }\end{array}$ & .08 & .80 & \\
\hline
\end{tabular}

SPECIAL OFFER, No. 42-One of each above 3 varieties for $15 \mathrm{c}$; or mixed colors, 3 for $10 \mathrm{c}$; 40c. per doz.; $\$ 3.50$ per 100 , postpaid.

\section{JONQUILS}

The Jonquils are lovely low-growing flowers, and like the hyacinths and crocus, bloom very early in the Spring. They are bright golden yellow and delightfully sweet-scented. Splendid for outdoor beds and borders, and equally fine for indoor Winter bloom.

Double Jonquils-Extra fine, deep yellow. 3c. each; 30c. per doz.; $\$ 2.00$ per 100 , postpair.

Narcissus Jonquilla, or Jonquils

Single Jonquils-Rich yellow, very fragrant. 6 for 10c.; 15c. per doz.; $\$ 1.00$ per 100 , postpaid 
"CONSIDER THE LILIES"

\section{THE TRUE BERMUDA EASTER LILY}

(LILIUM HARIRISII)

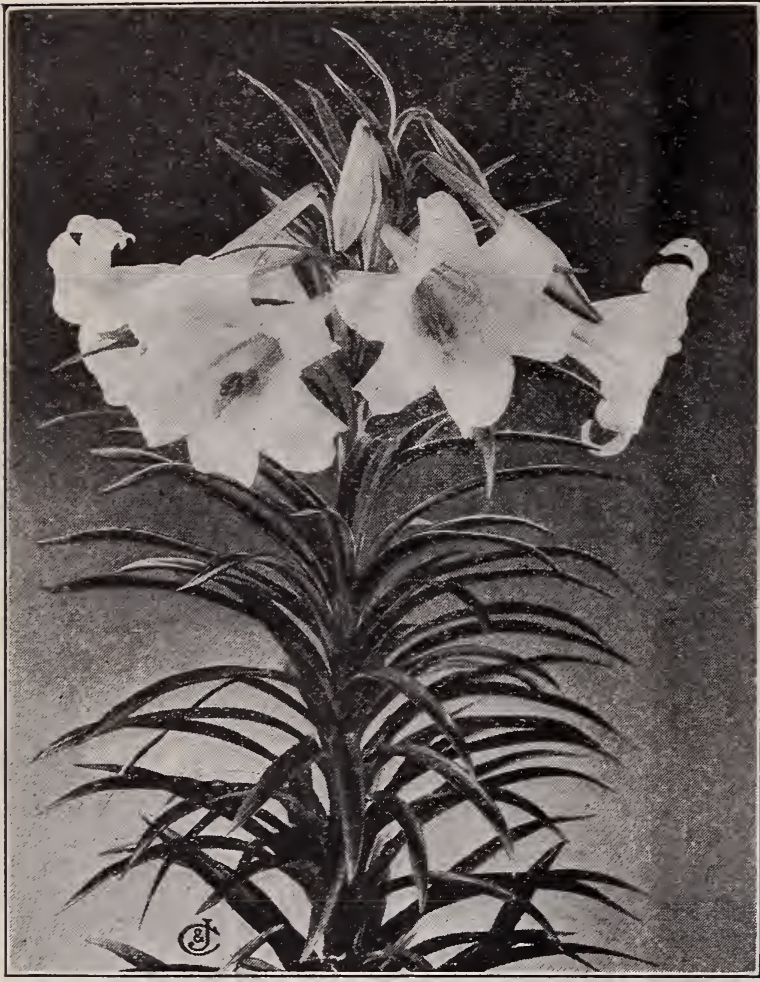

Bermuda Easter Lily

This is one of the grandest and most beautiful lilies ever seen, and the best of all for Winter flowering in pots; it grows easily and is sure to bloom. The flowers are pure snow-white, very large and fragrant, and borne in splendid clusters, six or eight at a time. Vast numbers of these splendid lilies are grown for church and house decoration every year. Plant in a pot or box which is at least six inches deep and well drained; good turfy soil with a little old, well-rotted manure is best; the bulb should be covered about one inch deep; firm the earth well around it, water thoroughly and set away in a cool place three weeks or more till the roots begin to start, then bring to the light-the window of an ordinary living room is about right. They require moderate heat with plenty of sunshine and water, and should bloom about three months from time of planting. Our Easter Lily Bulbs are of the very best quality and warranted to give satisfaction. We offer them in three sizes. Ready in August.

True Bermuda Easter Lilies delivered free in U. S. A.

Easter Lilies - Intermediate $\mid$ Each $\mid$ Doz. 100 size (6 to 7 in. in circumfer-

ence) these Bulbs should produce from 6 to 8 flowers, . .

Easter Lilies-First size standard Bulbs, ( 7 to 9 in. in circumference) these should produce from 8 to 12 flowers each,

Monstrous Size Bulbs- ( 9 to

11 in. in circumference.) These should produce 12 to 15 flowers,

\section{LILY CANDIDUM}

The Annunciation or Madonna Lily (ready in August) next after the Easter Lily, is one of the best lilies of all for Winter flowering in the house. It grows two to three feet high, bears grand clusters of extra large pure snow-white flowers, very sweet, and rivaling the Easter Lily in beauty. Also fine for outdoors. We offer good large bulbs, sure to bloom quickly. 12c. each, $\$ 1.25$ per doz., $\$ 9.00$ per 100 , delivered free in U. S. A.

\section{JAPAN EASTER LILY ( $\left.\begin{array}{c}\text { Lilium } \\ \text { Longiflorum }\end{array}\right)$}

This magnificent Lily is almost identical with Lilium Harrisii. It is somewhat later in flowering and therefore also useful for extending the season of bloom. It is beautiful snow-white and fragrant, and because of its great substance, size and lasting qualities is excellent for Easter decorations. Bulbs ready for delivery in October.

Delivered free in U.S. A. $\quad$ Each Doz. 100

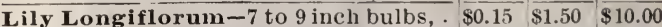
Lily Longiflorum-10 to 12 inch bulbs. $\quad .20|2.00| 15.00$

\section{New Philippine Lily \\ (Lilium Philippensis)}

A charming new lily from the Philippine Islands, throws up strong flower stalks 12 to 15 inches high, bearing beautiful large snow-white lilies delightfully fragrant, has proved hardy here and claimed to be superior to the Bermuda Easter Lily for Winter blooming. Fine Flowering Bulbs, 25c. each, $\$ 2.50$ per doz., postpaid.

\section{SPECIAL OFFER No. 35}

1 each of the 4 Lilies on this page, 50c., or in larger size, $75 \mathrm{c}$. postpaid.

NoTE-In Fall Planting, or when done flowering in the house, these lilies should be set four to five inches deep in the open ground, where they crun reinain, as they are entirely hardy if planted do(') and given a light covering of leaves or garden litter before hard freezing.

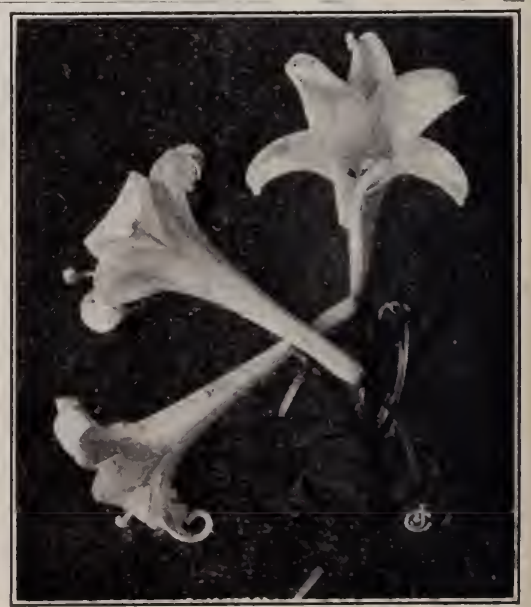

Lily Philiverusis 


\section{The Best Hardy Lilies}

These beautiful Lilies are quite hardy, but should be planted four or five inches deep and given a light covering of leaves or litter before the ground is deeply frozen. They should not be disturbed but left to grow on from year to year. They get larger and finer with age.

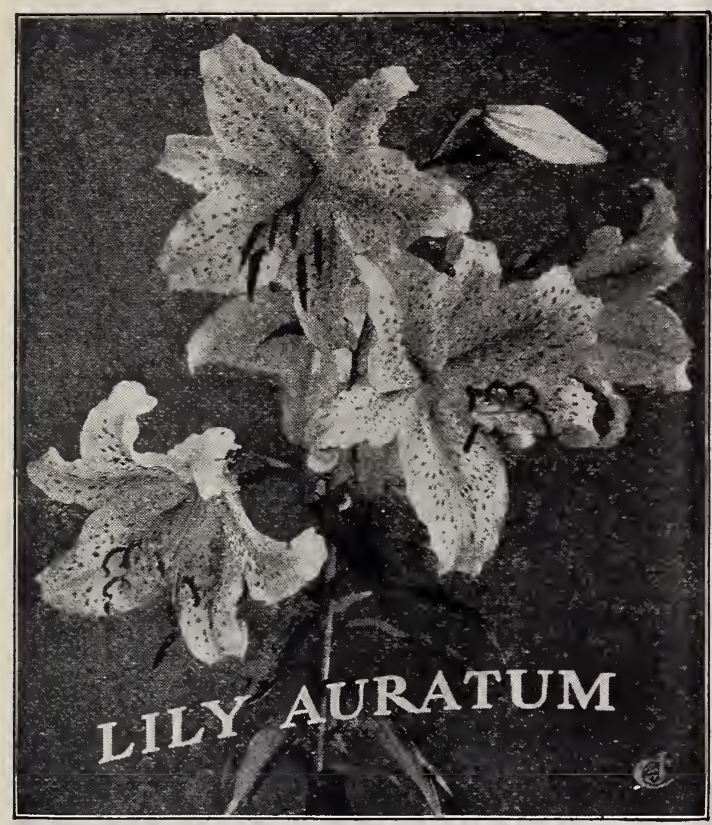

Most Lily Bulbs being of late maturity are not ready before October and November (the best time to plant them).

Umbellatum (Davuricum) - Beauti- Each Doz. 100 ful clusters of red, crimson, yellow and black. \begin{tabular}{c|r|r|r|} 
Wallaceii-Clear buff, elegantly spot- & & \\
ted with crime
\end{tabular}
Auratum Vittatum $R$ ub r $\mathbf{r}$ m- Prices delivered Probably the grandest lily in culti- free in U. S. A. \begin{tabular}{ll|l|l|} 
vation. Magnificent flowers 10 to 12 & Each Doz. 100
\end{tabular} inches across, clear waxy white with a burnished crimson stripe, half an inch wide, through the center of each petal, and the rest of the flower beautiful spotted crimsonhighly perfumed,

A uratum (The Golden Banded Lily of Japan)-Consiciered the Queen of Lilies, and one of the most beautiful of all. First size bulbs,

Extra size bulbs,

Canadense-One of our finest lilies, bearing graceful clusters of drooping bell-shaped red and $y$ ellow flowers

Elegans Atropurpureum - Large round handsome flowers with pointed petals, richly shaded with deep crimson and blood red

Krameri - Distinct from all other lilies. Flowers unusually large, beautiful soft rose, $\mathrm{Rich}$ scarlet and yellow flowers spotted with purplish brown, . .

Speciosum Album-Ex. large flow ers, pure snow-white, very sweetscented.

Speciosum Melpomone - Rich blood red, with clear frosty-white border; very handsome and hardy, Speciosum Roseum-Splendid large flowers, rose and white, spotted crimson; beautiful,

Speciosum Superbum (Turks Cap Lily)-Stands at the head of our native lilies; flowers bright orange red, thickly spotted with purple, Tenuifolium - The beautiful Coral Lily of Siberia. Grows 18 to 20 inches high and bears elegant clusters of bright coral red lilies,

Tigrioum Flora Plena (Double Tige $r$ Lily) - Extra large double flowers, bright rich orange, spotted black,

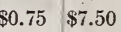

$.12 \quad 1.25$

\begin{tabular}{l|l|l}
.20 & 2.00 & 12.00
\end{tabular}

$.12 \quad 1.25$

\begin{tabular}{l|l|l}
.15 & 1.50 & 10.00
\end{tabular}

\begin{tabular}{l|l|l}
.12 & 1.25 & 9.00 \\
\hline
\end{tabular}
Pardalinum (The Leopard Lily) -

\begin{tabular}{l|l|l}
.15 & 1.50 & $\$ 10.00$
\end{tabular} \begin{tabular}{l|l|l}
.20 & 2.00 & 15.00
\end{tabular}

\begin{tabular}{l|l|l}
.15 & 1.50 & 10.00
\end{tabular}

\begin{tabular}{l|l|l|}
.20 & 2.00 & 12.00 \\
\hline
\end{tabular}

\begin{tabular}{l|l|l}
.15 & 1.50 & 10.00
\end{tabular}

\begin{tabular}{l|l|l}
.20 & 2.00 & 15.00
\end{tabular}

\begin{tabular}{l|l|l}
.15 & 1.50 & 10.00
\end{tabular}

SPECIAL No. 43 Any two 15c. kinds, 25c;; three 12c. kinds, 30c.; complete set OFFER N0.43 (14) $\$ 2.00$, or above 13, omitting Vittatum Rubrum, for $\$ 1.50$.

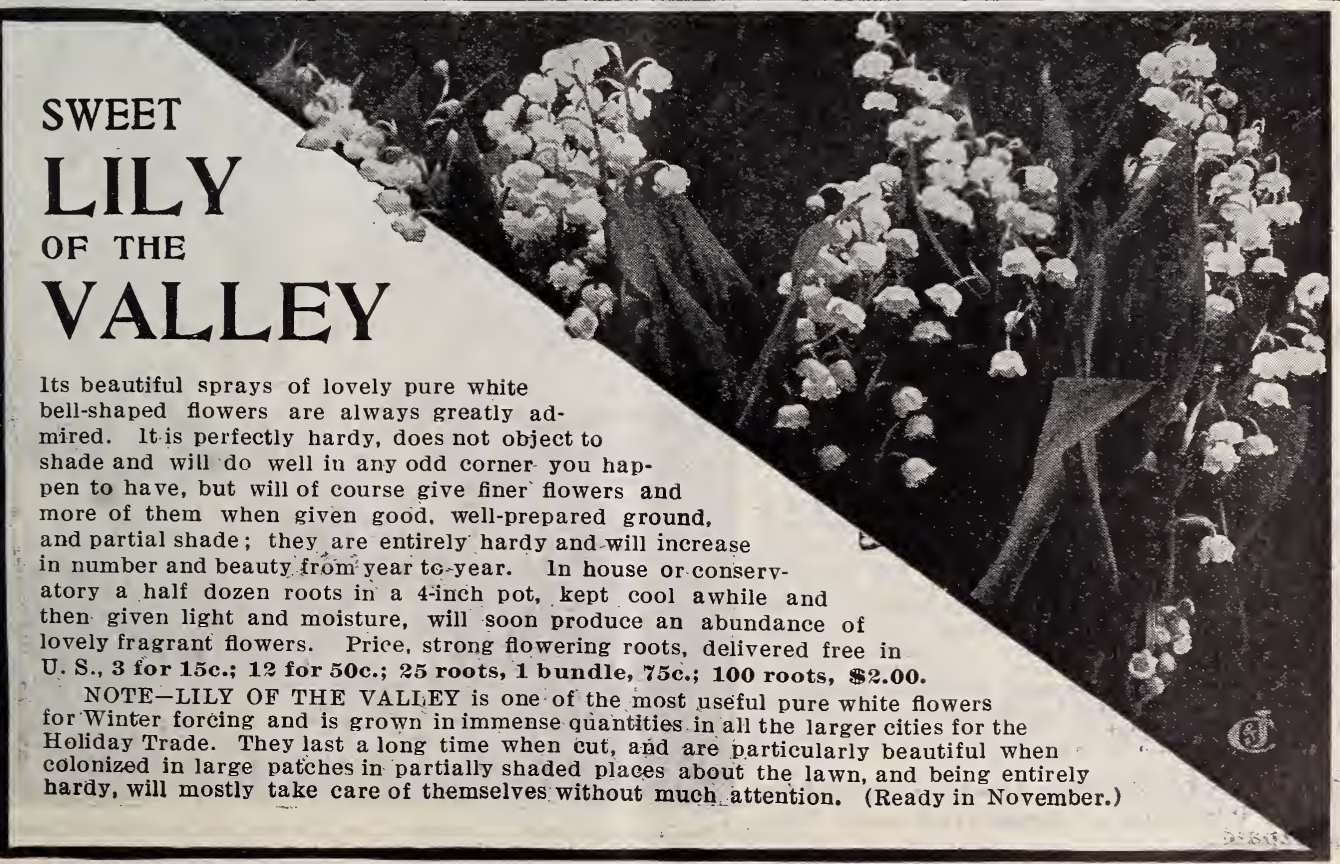




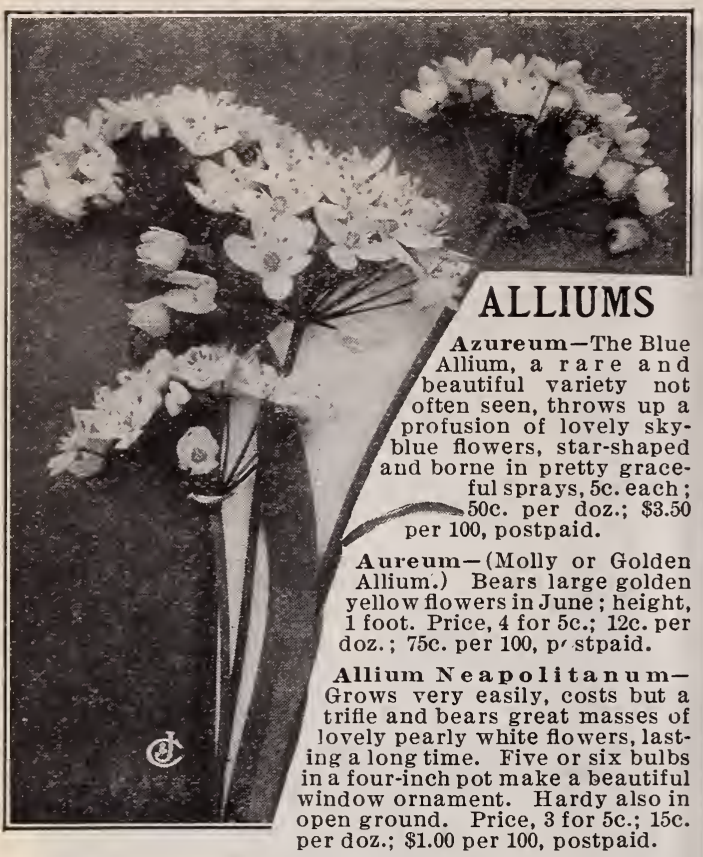

SPECIAL OFFER No. 44-1 Blue Allium, 4 Golden Yellow, 3 White, 8 for $15 \mathrm{c}$., postpaid.

\section{ANEMONES (Hardy Wind Flowers)}

Highly ornamental Winter and Spring blooming bulbs having both single and double flowers-color ranging through shades of blue, scarlet, rose, white, etc.

Anemone Coronaria-Large double flowers of brilliant colors ; fine mixed. 4 for $10 \mathrm{c} . ; 20 \mathrm{c}$. per doz.; $\$ 1.50$ per 100 , postpaid.

Anemone (Single Scarlet) - Bright dazzling scarlet, fine for pot culture and open ground. 3 for $12 \mathrm{c} . ; 25 \mathrm{c}$. per doz. ; $\$ 1.50$ per 100 , postpaid.

Anemone Apennina-Large blue flowers, early bloomer. 3 for 10c.; 20c. per doz.; $\$ 1.25$ per 100 , ppd.

\section{THE BLUE AFRICAN LILY}

Agapanthus Umbellatus-We offer fine bulbs of this splendid Blue African Lily, which is an exceedingly beautiful ornamental plant for the greenhouse or conservatory in Winter, and for pots or tubs on the lawn or piazza in Summer. The foliage is luxuriant and handsome, the flowers are borne in large clusters of 20 to 30 frequently measuring 10 to 12 inches across. The flower stalks grow 15 to 18 inehes high, and the flowers open in succession for several weeks the color is bright rich blue, very showy and attractive. Price, 25c. each $\$ 2.50$ per doz., postpaid. Ready in November.

\section{GUERNSEY LILY (Nerine Sarniensis)}

These beautiful Lilies are probably the most popular and useful of the Amaryllis family. For Autumn and Winter flowering they are extremely fine-throwing up stems from 18 to 24 in.-bearing large lily-like flowers of brilliant crimson and in the sunlight glisten as if sprinkled with gold dust. 20c. each; $\$ 2.00$ per doz., postpaid.

\section{A M A R Y L L IS \\ Q U E E N \\ $\mathrm{O} F$ \\ W I N T E R \\ F L O W E R I N G B U L B S}

May be kept in pots all the year round, or bedded out in the Summer

The Lovely Pink Amaryllis OR BELLAdONNA LILY-This is a grand variety, splendid for house in Summer. Bears grand, large, well-expanded flowers, lovely rose pink, finely penciled with silvery white and deliciously perfumed. Price, extra large bulbs for immediate bloom, 20c. each; $\$ 2.25$ per doz. Fine first size bulbs, 15c. each; 3 for $40 \mathrm{c} . ; \$ 1.50$ per doz., postpaid.

Amaryllis Equestre OR GLORIOSA most beautiful of the Amaryllis family. Very easy to grow and invaluable as a Winter bloomer Splendid large lily-shaped flowers 4 to 5 inches across, bright flashing orange scarlet, with ex quisite green and white star in the centre. Price, good first size bulbs, 15c. each: $\$ 1.50$ per doz. Extra large bulbs for immediate bloom, 20c. each $\$ 2.00$ per doz., postpaid.

Amaryllis Formosissima ORTHE MEXICAN LILY - Curiously shaped flowers, dark rich scarlet, very bright and handsome, easily grown and a sure quick bloomer; can be grown in water like the sacred lily, or if planted out in the Spring will bloom during the Summer. 12c. each $\$ 1.25$ per doz., postpaid.

Amaryllis Johnsonii One of the grandest of the Amaryllis family. Extra large and exceedingly beautiful flowers, deep red, elegantly striped with white, well known and very popular for house culture; may be planted out in Summer or kept in pots all the year round. Extra large blooming bulbs, 35c. each, postpaid. (See cut.)

Oueen Mary or Double white A MAThis is not a true Amaryllis, but belongs to the same family and is a most rare and beautiful flower, particularly valuable for pot culture and Winter bloom. Throws up flower stalks 12 inches high, crowned with large elegant lily-like flowers of waxy texture, pure snowy whiteness and deli cious fragrance. The outer petals are curiously reflexed, and the inner ones delicately fringed; a most lovely and charming flower, entirely distinct and different from all others. Strong blooming bulbs, 20c. each; 3 for 50c., nostpaid.

SPECIAL OFFER No. 45-One each of the five varieties of Amaryllis only $75 \mathrm{c}$. postpaid.

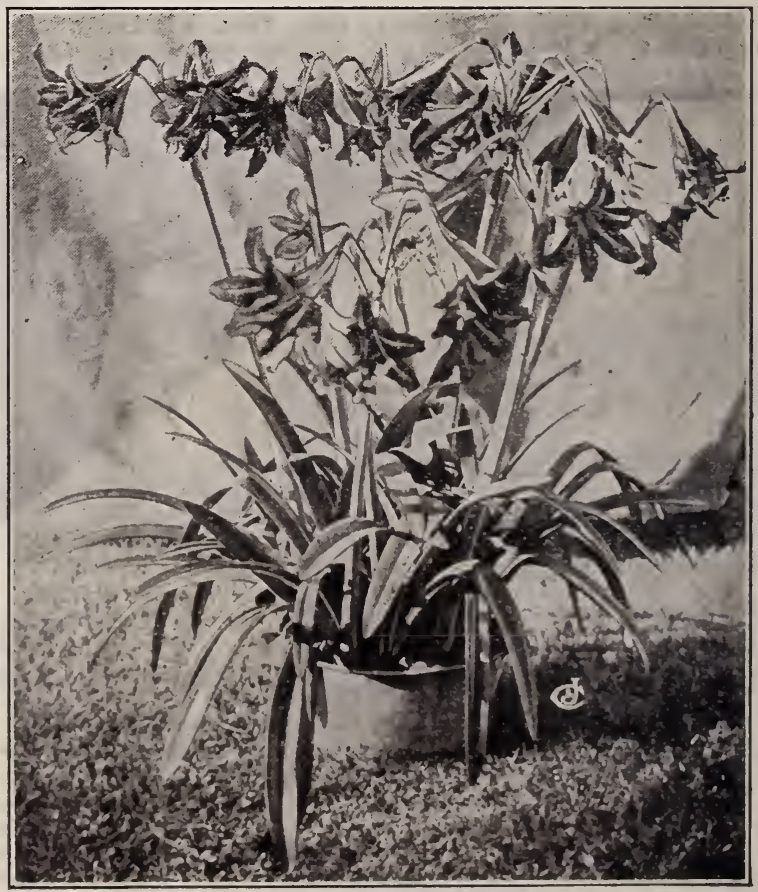

A tew Bulbs of our A. Johnsonii in this pan produced over 30 blooms at one time last Summer. It was a beautiful sight. 


\section{CALLA LILIES}

New Ever-Blooming Dwarf Calla Lily (Godfrey)

This New Dwarf Hybrid is a true ever-blooming variety, grows about 18 inches high, and will produce three times as many blooms as the old white Calla. The flowers are equally large and perfect in form. Very much whiter and delightfully fragrant. When properly treated it will grow and bloom the whole Summer and Winter, though of course a short season of rest is always beneficial. Price, fine growing plants, $25 \mathrm{c}$. each ; 3 for $65 \mathrm{c} .$, postpaid.

New Yellow Calla ( $\left.\begin{array}{c}\text { Mrs. } \\ \text { Roosevelt }\end{array}\right)$ Spotted Leaf

This is the finest Yellow Calla yet produced. Flowers large and clear bright yellow, foliage deep green finely spotted pure white, fine for house

\section{New Dwarf Sweet-Scented Calla Lily}

Originated in California; grows low and compact. A most constant and abundant bloomer, and delightfully sweet-scented. Finest Dwarf Sweet-Scented Calla Lily yet produced. Price, dry bulbs, 15c. each; $\$ 1.50$ per doz., postpaid.

\section{SPECIAL OFFER No. 61

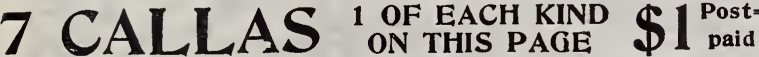

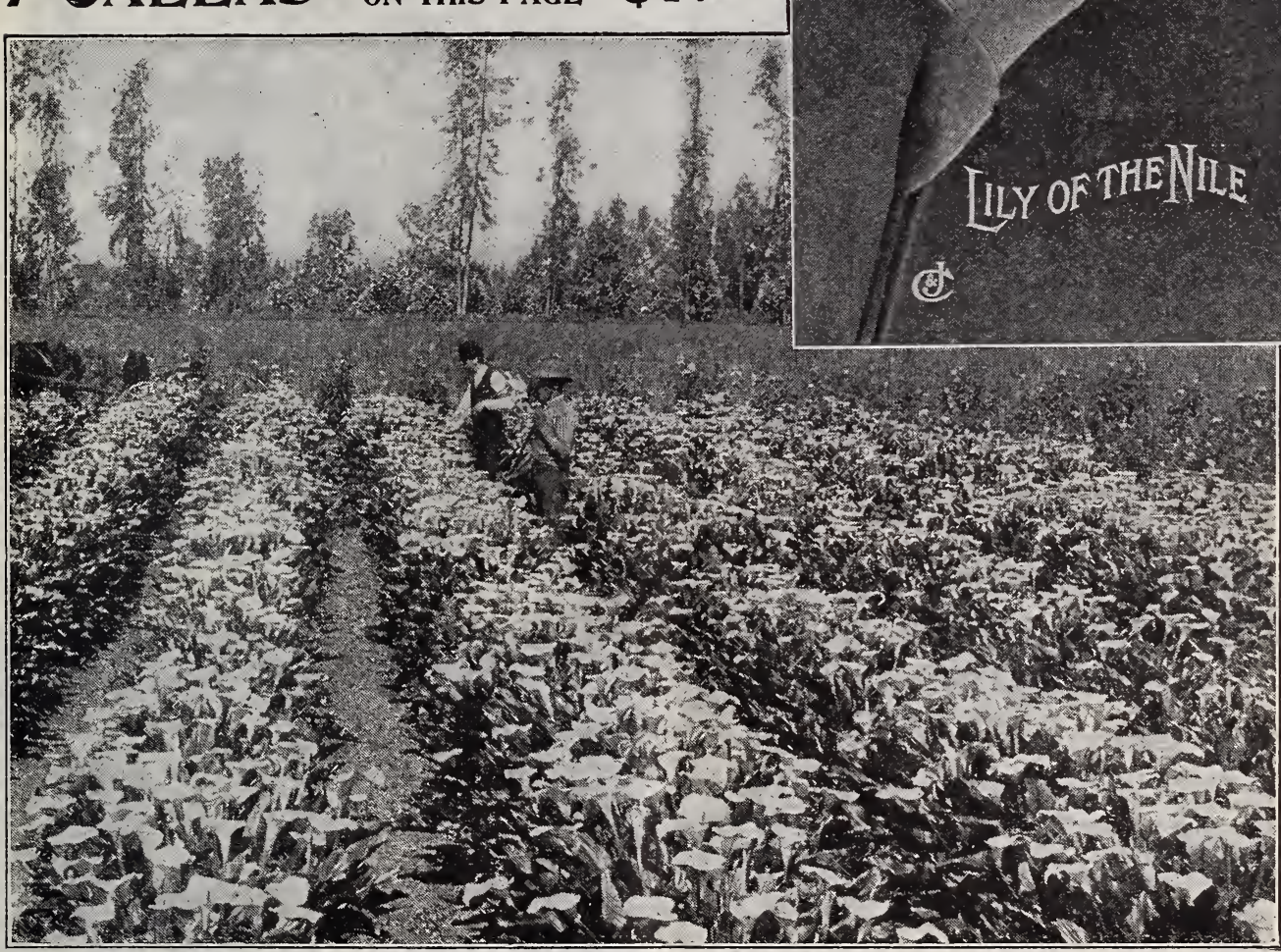

Notice how abundantly these Callas bloom.

White Calla (Aethiopica) or Lily of the Nile -This is one of our most highly the middle of June until September, then potted in good rich soil, in a 4 or 6-inch pot, and given plenty of heat and moisture. When well established a good plant will bear six to eight lilies at a time. Dry bulbs only. Extra la rge bulbs, 20c. each ; 2 for 35c.; $\$ 2.00$ per doz. First size blooming bulbs, 15c. each; 2 for $25 \mathrm{c}$.; $\$ 1.50$ per doz., postpaid.

New Dwarf Calla (Litte Gem) - Among the existence has the reputation of bearing twice as large kind, and We send extra fine imported bulbs, ready for potting. the very best for quick and abundant bloom. $10 \mathrm{c}$. each; $\$ 1.00$ per doz.; $\$ 5.00$ per 100 , postpaid.
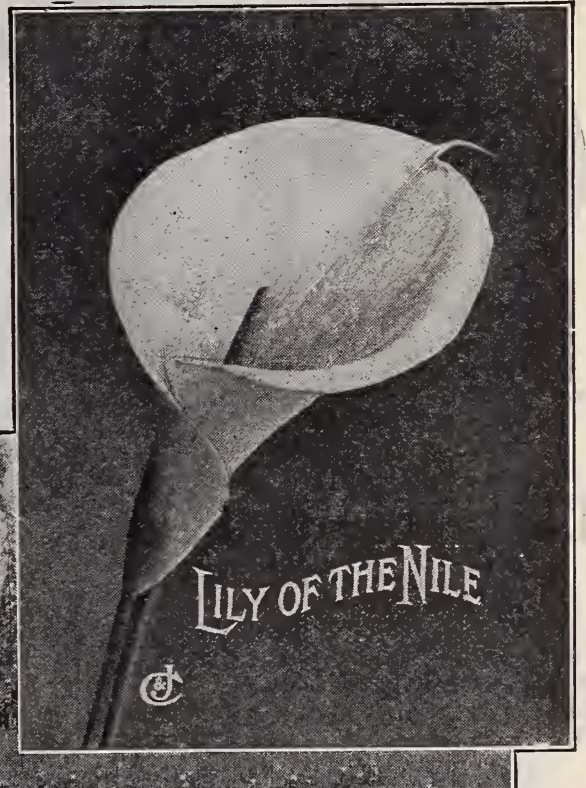

SPECIAL OFFER No. 46-1 White, 1 Little Gem, 1 Black, 1 Red-these four Callas for $50 \mathrm{c} .$, postpaid 


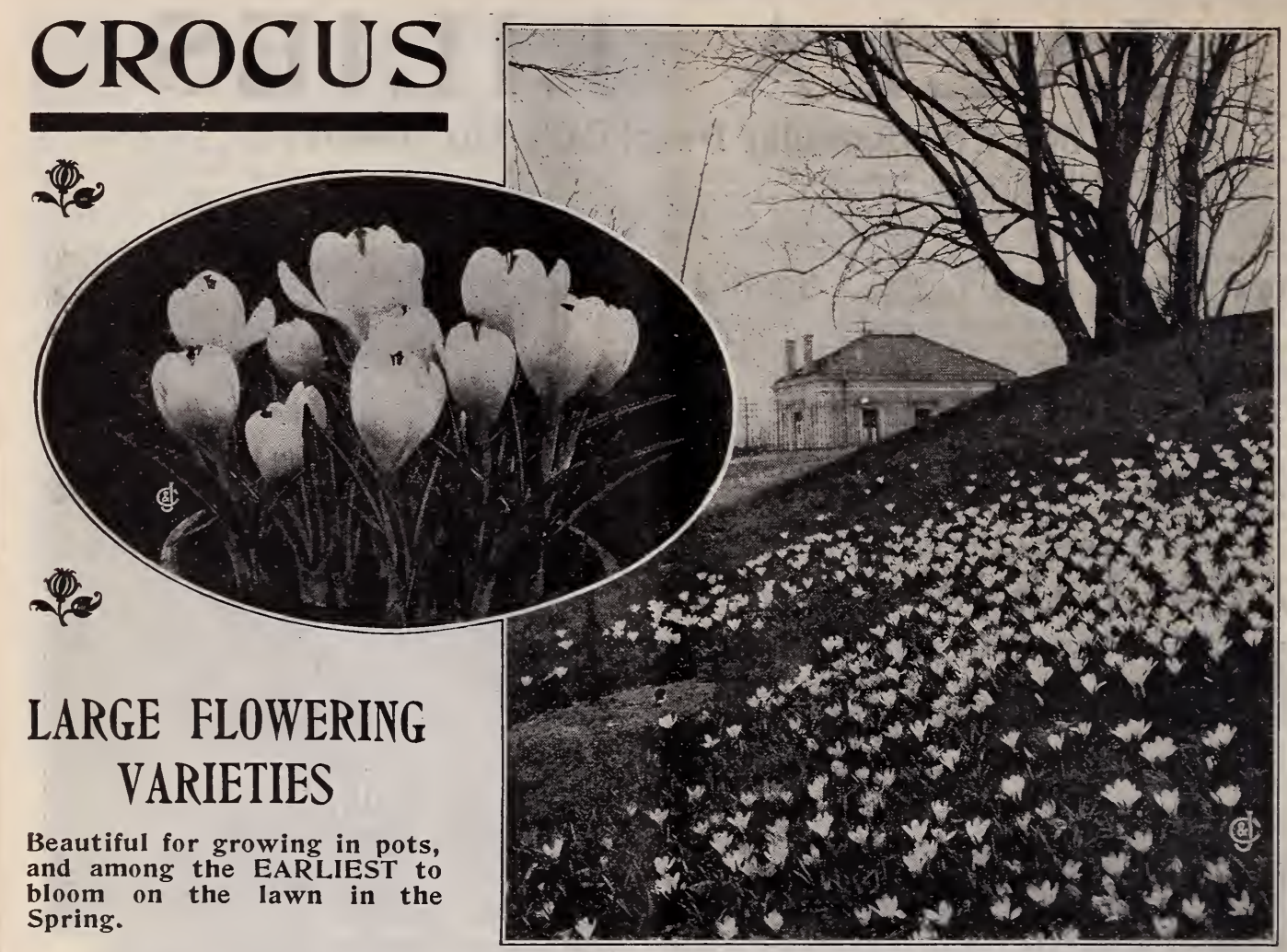

Among all the pretty flowers of Spring, none is greeted with a heartier welcome than the Crocus. Their flowers are lovely in form, and of the brightest colors-Pure White, Golden Yellow, Purple, Pink and Variegated. They are entirely hardy, and like a rich dry soil and sunny location. They are suitable for planting in beds and borders, also for edging in ribbon lines of any desired color, for planting in the grass in lawn or yard. Crocus are also very highly valued for House Culture. They bloom very quickly and are so cheap that all can afford to have them. Ours are the Improved Strains, noted for large flowers and brightest colors. Plant early in the Autumn.

\section{LARGE FLOWERING NAMED CROCUS}

Baron von Brunow-Very deep dark rich purple, a grand sort.

Caroline Chisholm-Large pure white, free flowering, one of the best.

Cloth of Gold-Blooms very early, fine handsome feathered flowers, golden yellow, tinged with purple and scarlet.

Cloth of Silver-Beautiful silvery white flowers, striped with violet, very lovely.

David Rizyio-Extra large-flowers, dark rich purple, a grand variety.

Mont Blanc-Extra large and beautiful, pure white.

Sir Walter Seott-White, striped purple, very large.

Price, for any the above named varieties-12c. per doz.; 75c. per $100 ; \$ 6.00$ per 1000 , delivered free in U. S. A.

\section{SPECIAL OFFER No. 52}

4 each of above 7 kinds, 28 in all, for $25 \mathrm{c}$. 10 " 7 " 70 " " $50 \mathrm{c}$.

\section{NEW GIANT FLOWERING CROCUS}

These giant flowering crocus are the finest rarieties obtainable; each bulb will produce several flowers.

King of the Whites-Extra large long flowers, the largest white crocus.

King of the Yellows-Deep golden yellow, immense bloomer, very bright and handsome.

King of the Purples-Dark rich purple, the largest of all purples.

King of Lilacs-Inside of flower blue, outside striped lilac.

King of Stripes-Outside striped blue on light ground, inside blue.

King of Pinks-Extra large flowers of soft rosy pink, rare and distinct.

Price, for any of the above named varieties of King Crocus, 30c. per doz.; $\$ 2.00$ per 100 , delivered free. Or the above in mixed colors, 20c. per doz.; $\$ 1.25$ per 100 ; $\$ 10.00$ per 1000 , delivered.

\section{SPECIAL OFFER No. 53}

4 each of above $6 \mathrm{kinds}, 24$ in all, for $50 \mathrm{c}$. 10 " 6 " 60 " " $\$ 1.25$

\section{BEST MIXED CROCUS IN SEPARATE COLORS}

I) 07.

White and Light,

\section{$\$ 0.10$}

Purple and White,......: .10

Striped and Variegated, .... . . 10
100

0.50

.50
1000

$\$ 4.00$

4.00

4.00
Doz.

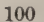

Yellow, 1st size, .

$\$ 0.10$

$\$ 0.50$

1000

The prices include postage, which is paid by us. 


\section{ARABIAN STAR OF BETHLEHEM ( $\left.\begin{array}{c}\text { Ornithogalum } \\ \text { Arabicum }\end{array}\right)$}

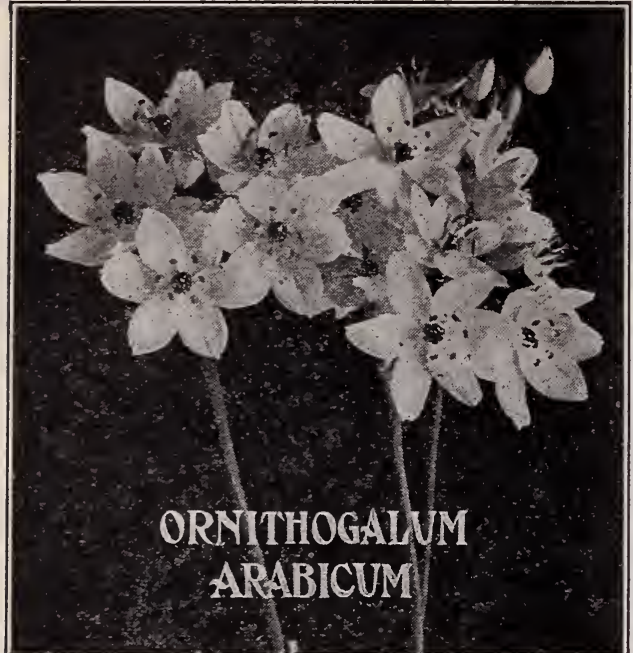

MissourI, January 25, 1908.

THE CONARD \& JONES CO.

Genilemen-I have been buying plants, bulbs and seeds from you for over eight years, and have always found everything as you represented it to be. Yours truly, FRANK GordoN.
Arabian Star of Bethlehem-A really beautiful bulb for pots, large and solid like a Hyacinth, and requiring the same treatment; flower stalks 18 to 20 inches high, bearing immense clusters of large, pearly white flowers with jet black center, rich aromatic fragrance. The flowers last a long time and are almost unrivaled for beauty and fragrance They do nicely in open ground if protected from hard freezing. $4 \mathrm{c}$. each, 6 for $20 \mathrm{c} ., 35 \mathrm{c}$. per doz., $\$ 2.85$ per 100 , postpaid.

\section{SCILLA CLUSII}

The Peruvian Hyacinth or Cuban Lily is a very grand and striking plant for house culture; throws up a strong, bold flower stem, with long lance-shaped leaves, and bearing one enormous pyramidal cluster of rich bright blue star-shaped flowers. It is very easily' grown, commences to bloom a bout midwinter and continues a long time. When warm weather comes, plant in open ground, and if taken in before freezing, it will be ready to bloom again next Winter. 10c. each, $\$ 1.00$ per doz., postpaid.

\section{SCILLA SIBERICA}

One of the earliest flowering and most beautiful bulbs we have, equally valuable for Winter blooming in pots and for bedding in open ground; perfectly hardy and sure to bear an abundance of bright blue flowers very quickly indoors: it will bloom from Christmas to April. 2 for $5 \mathrm{c}$., 20c. per doz., $\$ 1.25$ per $100, \$ 10.00$ per 1,000 , postpaid.

\section{LEUCOJUM VERNUM (SPRING SNOWFLAKE)}

One of our earliest Spring flowers, beautiful snowy blossoms like giant snowdrops, tipped with green. $3 \mathrm{c}$. each, $30 \mathrm{c}$. per doz, $\$ 1.50$ per 100 , postpaid.

\section{WINTER=BLOOMING OXALIS}

These beautiful Oxalis are the true Winter-blooming kinds. Absolutely unequaled for pots, baskets, vases, window boxes, etc. They begin blooming very quickly and continue to throw out their lovely buds and blossoms every day all Winter. Nothing finer for window culture.

Oxalis Bermuda Buttercup - Bears lovely bright golden yellow flowers all Winter and Spring; frequently shows hundreds of buds and flowers at a time, and is one of the finest Winter-blooming bulbs for the window garden and living room ever introduced. $4 \mathrm{c}$. each, 35c. per doz., $\$ 2.50$ per 100 , postpaid.

Grand Duchess Oxalis-A California variety of dwarf sturdy growth bearing large clusters of ex quisite flowers borne well above the foliage. We offer the three following

\begin{tabular}{lrrr} 
& Each & Doz. & \multicolumn{1}{c}{100} \\
white, & $\$ 0.04$ & $\$ 0.35$ & $\$ 2.50$ \\
pink, & .04 & .35 & 2.50 \\
lavender, & .04 & .35 & 2.50
\end{tabular}

Double Yellow Oxalis (Lutea. Fl. PI.)-Large double flowers, bright rich ycllow. 5c. each, 40c. per doz., $\$ 3.00$ per 100 , postpaid.

Oxalis Boweii-Large flowers, bright rich pink. 4c. each, 25c. per doz., $\$ 1.75$ per 100 , postpaid.

Snow Ball (Multiflora Alba)-Large double pure white flowers. 4c. each, $25 \mathrm{c}$. per doz., $\$ 1.75$ per 100 , postpaid.

Versicolor-Deep rose with white center, beautiful. 4c. each, $25 \mathrm{c}$. per doz., $\$ 1.75$ per 100 , postpaid.

Fine Mixed Oxalis, 25c. doz., \$1.25 per 100, postpaid.

The six named kinds, one each, 12c. Two each, twelve in all, 20c., postpaid.

\section{GRAND FLOWERING GLOXINIAS}

Dry Bulbs in Separate Colors Ready in November

The Gloxinias are known as among the choicest and most beautiful flowering plauts we hare for Winter and Spring bloom. They are of most gorgeous and exquisite colors; some are spotted and mottled, others beautifully variegated, and all indescribably rich and velvety. When done blooming, the bulbs should be dried off and laid away till time to plant again.

Emperor Frederick-Red with a pure white border.

Defiance-Rich crimson scarlet

Mt. Blane-Large pure white.

Tiger Spotted-Striyed and spotted.

Price of any of the above-named varietles, $15 \mathrm{c}$. each, 4 for $50 \mathrm{c} ., \$ 1.50$ per doz., postpaid.

Mixed Varieties, 12c. each, \$1.25 per doz., $\$ 9.00$ per 100 , postpaid.

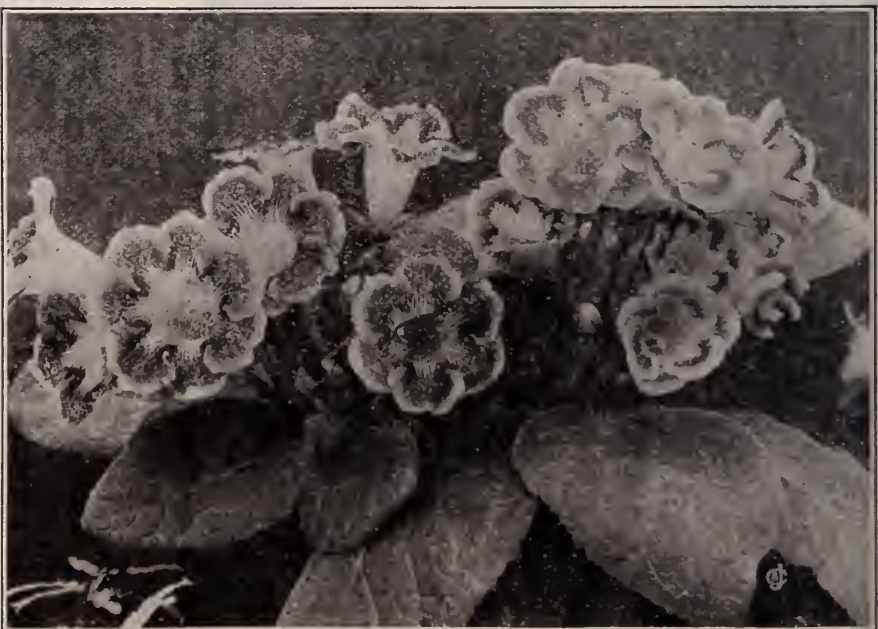

Gloxinia. Note the luxuriance of bloom 


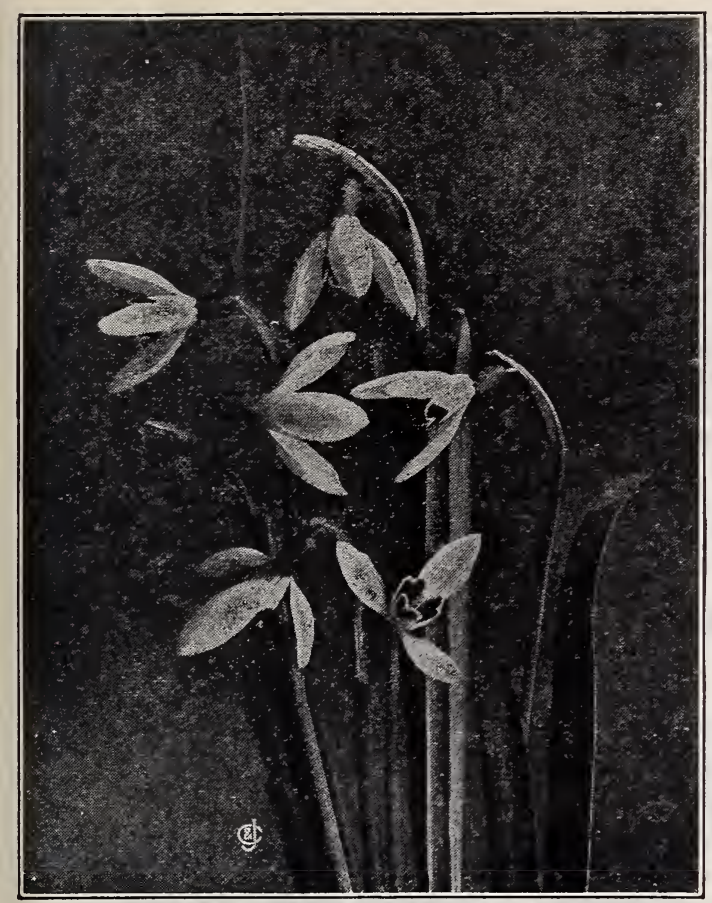

SNOW DROPS

(GALANTHUS)

Snow Drops are the earliest of all Spring flowers, as they bloom a few days before the Crocus and Scilla. Their drooping white blossoms are exceedingly pretty and graceful.

Single Snow Drops-15c. per doz.; $\$ 1.00$ per $100 ; \$ 7.50$ per 1000 , postpaid.

Double Snow Drops - Flowers perfectly double ard pure snow white. 3 for 10c.; 30c. per doz.; $\$ 2.00$ per 100 , postpaid.

Giant Snow Drops-(Elwesi). The largest and most beautiful of all Snow Drops, flowers pure snow white and deliciously sweet, extra fine for pots and kedding. 2 for 5c.; 20c. per doz.; $\$ 1.10$ per 100 ; $\$ 8.00$ per 1000 , postpaid.

\section{"GLORY OF THE SNOW"}

Chionodoxa Luciliae-Very early. A lovely $\nabla$ ariety producing large clusters of beautiful azure blue flowers with clear white centre, very handsome and desirable. 2 for 5 c.; 20 c. per doz.; $\$ 1.10$ per 100 ; $\$ 8.00$ per 1000 , postpaid.

Giant Chionodoxa - (Chionodoxa Gigantea) - Much larger flowers than the above, lovely violet blue with white eye, very striking and beautiful. 2 for 5c.; $20 \mathrm{c}$. per doz.; $\$ 1.10$ per $100 ; \$ 8.00$ per 1000 , postpaid.

\section{MISCELLANEOUS BULBS}

THE PRICES GIVEN INCLUDE UNITED STATES POSTAGE, WHICH IS PAID BY US. Bulb Cultural Directions will be sent with each order. See also page 4.

Babiana-Charming little Winter blooming bulbs, delightfully sweet scented. 3 for 10c.; 35c. per dozen.

Brodiaea Coccinea (Floral Fire Cracker)-Flowers deep rich crimson, tipped with white. 4c. each; 35c. per doz. Calochortus, or Mariposa Tulip-Of many beautiful colors. 4c. each; 30c. per doz.

Fritillaria Meleagris-Fine bulbs for bedding out, also house culture; entirely hardy. 4 for 10c.; $25 \mathrm{c}$. per doz. Gladiolus, The Bride-These are very fine for Winterflowering in the house, six bulbs can be planted in one six-inch pot. The flowers are large, pure snow-white, and borne in long slender spikes, very beautiful and largely used for cut flowers. Fine blooming bulbs, 3 for $10 \mathrm{c} . ; 25 \mathrm{c}$. per doz.; $\$ 1.35$ per 100 , postpaid.

Iris Florentina-Pure white with elegant blue and yellow markings. 5c. each; 50c. per doz.; $\$ 2.00$ per 100 .

Iris, Belle Chionise-Deep golden yellow, very fine. 4 for 10c.; 20c. per doz.; \$1.25 per 100 .

Iris, The Queen-Large pure white flowers. 4 for 10c.; 20c. per doz.; $\$ 1.25$ per 100 .

Peacock Iris-Very beautiful and fine for pots and garden culture. 3 for 10c.; 30c. per doz.; \$1.75 per 100 .

Iris, The Darling-Azure blue and royal purple with yellow markings. 4 for 10c.; 20c. per doz.; $\$ 1.25$ per 100 . Iris, Prince of Orange-Orange yellow with purple spots. 4 for 10c.; 20c. per doz.; $\$ 1.25$ per 100.

Spanish Iris (Iris Hispanica)-Fine for pot culture and bedding out. Mixed colors. 3 for 5c.; 15c. per doz.; $\$ 1.00$ per 100 .

PALESTINE IRIS-Flowers large and remarkablerivaling the finest orchids in beauty and variety of col. oring and markings, especially recommended for house culture. We offer 4 varieties, as follows :

Iris Atropurpurea-Extra large flowers, deep dark purple, almost black. 3 for 10c.; $25 \mathrm{c}$. per døz.

Iris Histrio-Deep sky blue variegated with shades of white, yellow and brown. 3 for 10c.; 25 c. per doz.

Iris Marie-Bright lavender pink, shaded violet. 3 for 10c.; 25c. per doz.
Iris Sarl Nazarenae-Rich canary, elegantly variegated with crimson and blue. 3 for $10 \mathrm{c} . ; 25 \mathrm{c}$. per doz.

Ixias-Beautiful little winter flowering bulbs, throwing up slender spikes of bloom. Many different colors. 3 for 5c.; 15c. per doz.; 75c. per 100 .

RANUNCULUS (Fair Maids of France)-These sturdy dwarf-growing plants are highly valued for pot culture and bedding out. They bloom quite early and will produce large double brilliant colored flowers. We offer 3 varieties.

Double Turban Mixed-Large and early. Many brilliant colors. 2 for $5 \mathrm{c}$; $20 \mathrm{c}$. per doz.; $\$ 1.25$ per 110 , postpaid.

Double Giant French Mixed-Strong vigorous grow. ers, bearing immense gorgeous flowers. 2 for $5 \mathrm{c}$.; $20 \mathrm{c}$. per doz.; $\$ 1.25$ per 100 , postpaid.

Double Persian Mixed-Rose-shaped flowers, very double, rich, handsome colors. 2 for 5 c.; 20c. per doz.; $\$ 1.25$ per 100 , postpaid.

Scarlet Freesia (Anomatheca Cruenta)-(Ready in November)-This resembles the White Freesia in many respects, except that its flowers are bright scarlet, shaded crimson, and though it does not flower quite so early, it is very bright and handsome. Price, 4 for 10c.; 25c. per doz.; $\$ 1.50$ per 100 .

Sparaxis-Many beautiful colors. Spotted, streaked and flushed. Fine for pot culture. 3 for $5 \mathrm{c} . ; 15 \mathrm{c}$. per doz.; 75c. per 100.

Tritonia-Fine graceful sprays of soft richly colored flowers. 3 for 10c.; 25 c. per doz.; 75c. per 100.

Tritelia Uniflora-(Spring Star Flower)-Charming fairy-like white flowers for Winter bloom, also bedding out. 3 for 5 cts.; 15 cts. per dozen; 75c. per 100 .

Tritelia Blue-Like the above except flowers are lovely VIOLET BLUE. 3 for 10c.; 25c. per doz.; 75c. per 100 .

Zephyranthus or Fairy Lilies-Beautiful dwarf lilies, flowering abundantly in pots in Winter or in open ground in Summer, two varieties.

Z. Atamasco-Pure white. 3 for 10c.; 30c. per doz.; $\$ 2.00$ per 100.

Z. Rosea-Clear rose pink. 5c. each; 50c. per doz.; $\$ 3.50$ per 100 . 


\section{New Emerald Feather Asparagus}

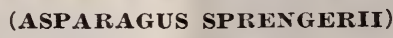

This is undoubtedly one of the handsomest and most valuable evergreen trailing plants for the house and conservatory ever introduced. It is especially valuable for pots, vases, baskets, etc., covering all with its beautiful sprays of lovely green feathery foliage, which can be cut freely and is very useful for bouquets, wreaths, and all kinds of floral decorations. It makes a charming ornamental plant for the window or conservatory in Winter, and is equally valuable for vases, baskets, porch boxes in Summer. It is a strong vigorous plant, very easily grown, requires but little care and keeps on growing, fresh and green, year after year. Price, 15c., $20 \mathrm{c}$. and $25 \mathrm{c}$. each; $\$ 1.50, \$ 2.00$ and $\$ 2.50$ per doz., postpaid. Extra size from 5 and 6 -inch pots, $35 \mathrm{c}$. and $50 \mathrm{c}$. each by express.

\section{Asparagus Plumosa}

\section{Climbing Lace Fern}

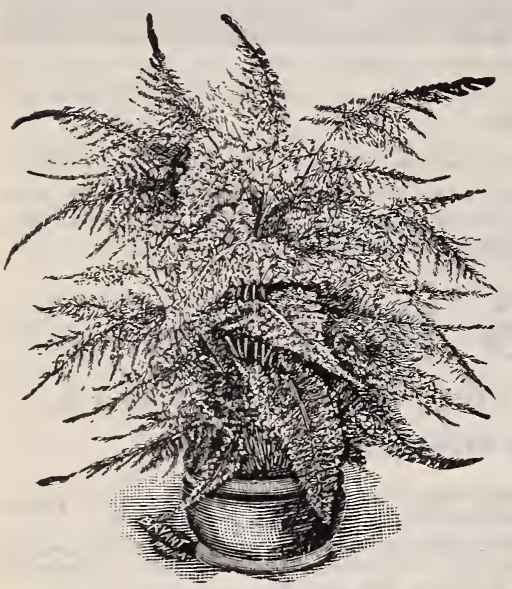

A finer and mor e delicate plant than the Sprengerii, but hardy and easily grown; very satisfactory for window and

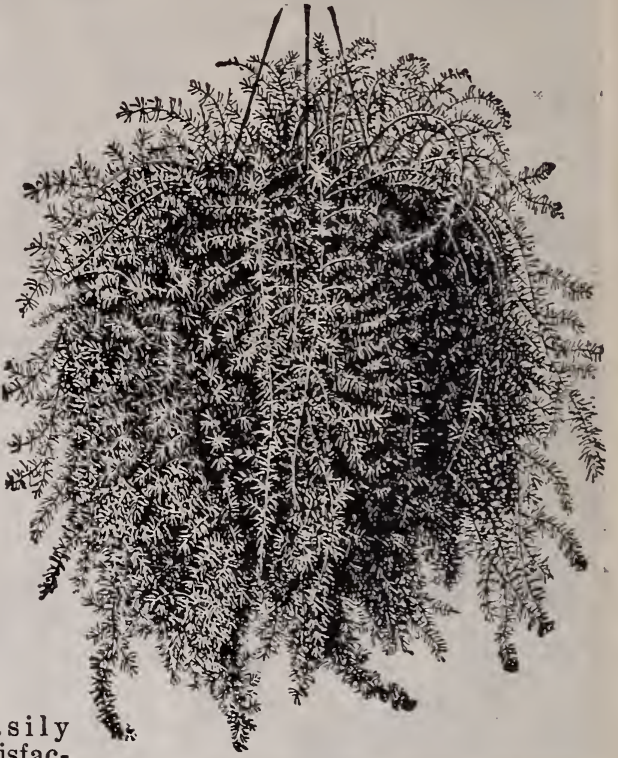

Emerald Feather Asparagus house culture ; an ex-

tremely graceful window climber, bright, green, feathery foliage, as fine as the finest silk or lace. The fronds retain their freshness for weeks when cut, and are greatly admired for floral decorations. An exceedingly beautiful plant for house and conservatory, and will thrive nicely in the temperature of an ordinary living room. Entirely unequaled for the grace and beauty of its lovely spray-like fronds.

Price, nice thrifty plants, 15c. and 20c. each; $\$ 1.50$ and $\$ 2.00$ per doz., postpaid; larger sizes, $40 \mathrm{c}$. and 50c. each, by express.

Asparagus Plumosa

\section{Newport Parlor Fern}

(Nephrolepis Scottii)

This is undoubtedly one of the most beautiful plants for house decoration ever offered. Our engraving is made from a photograph, and therefore shows the plant exactly as it appears ; it resembles the Boston Fern in some respects, but grows more erect, has shorter, narrower fronds and makes three times as many of them; has taken gold and silver medals at all the great shows wherever exhibited.

Price, 15c., 20c. and 30c. each, according to size, postpaid. Fxtra size for immediate effect, 50c., 75c. and $\$ 1.00$ each, by express, at purchaser's expense.

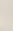

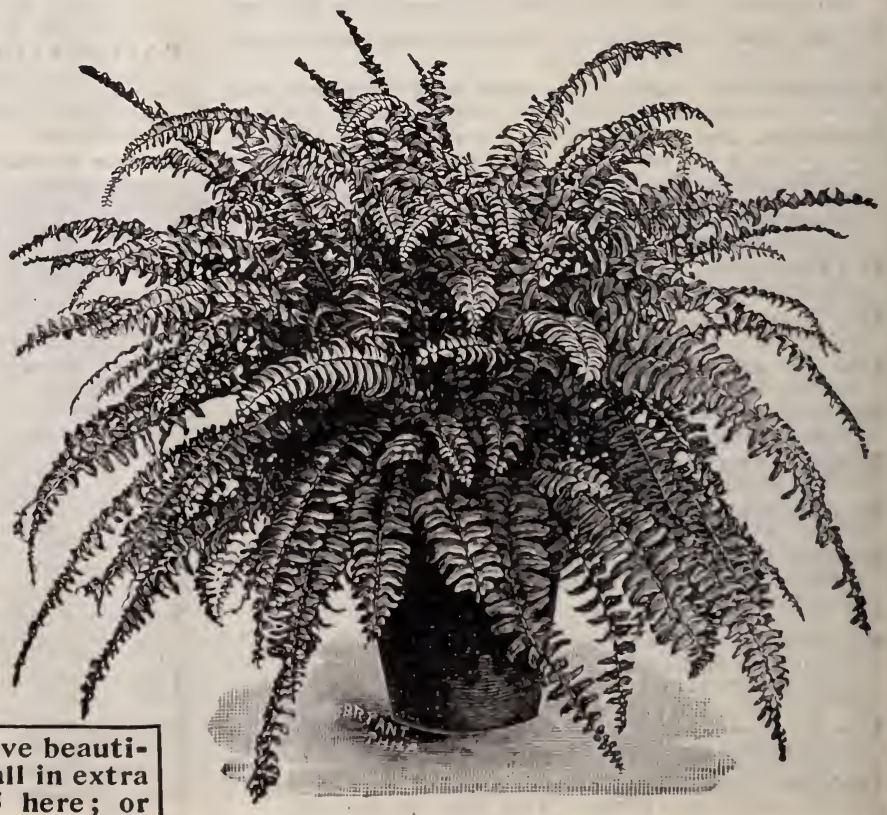

The Newport Parlor Feru ful plants, $40 \mathrm{c}$., postpaid ; or all in extra size, by express, 3 for $\$ 1.15$ here; or $\$ 1.50$ delivered in U. S. A. 


\section{Ornamental Ferns}

"WHITMANII"-Finest One Yet

and undoubtedly the most popular. Rather dwarf in growth, but graceful, very compact, dense and feathery. Each frond or branch has a double row of perfect little fronds set at right angles to the midrib, and so thick they seem almost crowded. It is a healthy, vigorous grower, constantly unfolding fresh fronds of light green that contrast exquisitely with the deep green of the older fronds. It is somewhat like the fern shown in the illustration opposite, but decidedly more fluffy, more delicate and beautiful (see outline drawing No. 1). Price, 25c. each, postpaid Larger size, $75 \mathrm{c}$., express.

\section{NEW FILMY FERN}

(Nephrolepis Todeaoides)

This splendid new fern comes from England, where it captured a first-class certificate, both from the Royal Horticultural Society and the Royal Botanic Society of London. It makes a strong compact growth with bold heavy foliage. The fronds are distinctly tripinnate or three times divided. The effect is altogether very impressive, and we believe this variety is destined to become very popular. Price, strong plants, 35c. and 60c. each, postpaid.

\section{THE BOSTON FERN \\ (Nephrolepis Exaltata)}

This is the old standby and still one of the best. The beautiful fronds grow two to five feet long and droop over in the most delightful way. (See illustration, frond No.3.) Price, good strong plants, $15 \mathrm{c}$. 20c. and 25c. each, postpaid. Larger size, 40c., 50c., $75 \mathrm{c}$ and $\$ 1.00$, by express.

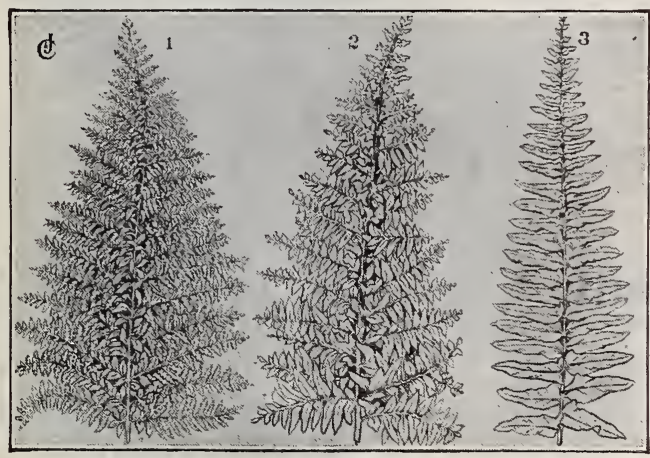
Whitmanii
Piersonii
Boston

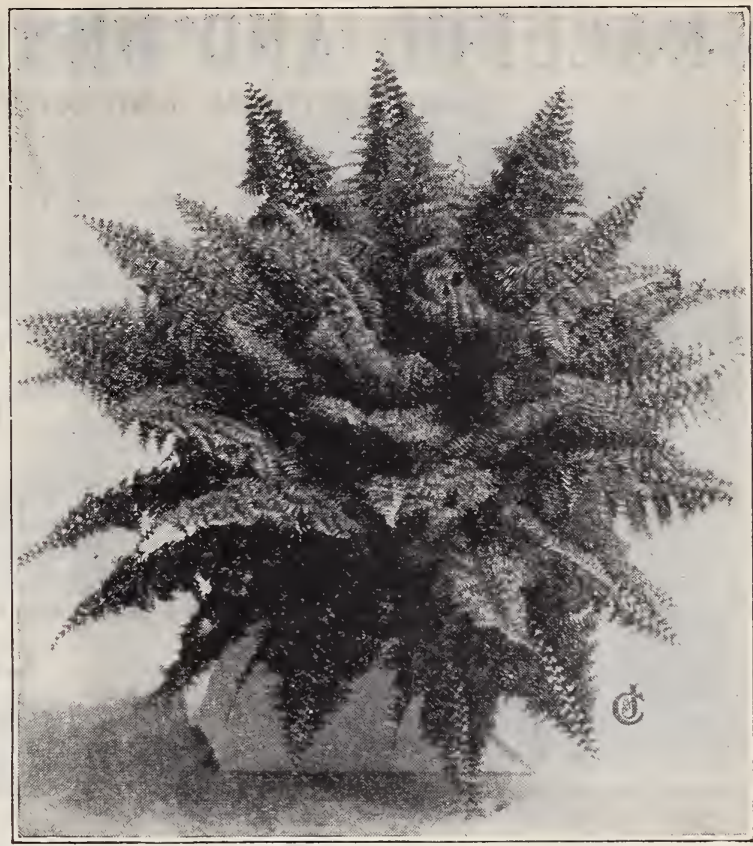

One of the New Nephrolepis Ferns

\section{NEW OSTRICH PLUME FERN (Nephrolepis Piersonii)}

Undoubtedly one of the finest plants for house decoration ever offered, it is a strong, vigorous grower, resembling the Boston Fern somewhat, but the fronds are much heavier and more feathery, and arch over in a most graceful manner, showing two shades of green and producing a lovely mossy effect which adds greatly to its beauty; a quick rapid grower, and can be depended on to make a fine display at once (see outline drawing No. 2). Price, strong plants, 15c., 25c. and 35c. each, postpaid. Extra size plants for immediate effect, 50c., 75c. and $\$ 1.00$, by express.

\section{CHOICE FERNS FOR THE HOUSE}

Maiden's Hair Fern (Adiantum Cuneatum)Always in great demand for table and house decoration; will thrive nicely in parlor or living room, and grow more beautiful each year. 15c., 20c. and 25c. each, postpaid.

Mount Washington Fern (Davallia Stricta)-Has long graceful finely cut foliage, rich Nile green, nice for house or conservatory, also for planting out; hardy. 15c. and 20c. each, postpaid.

Polystichum Setos $\mathbf{n} \mathbf{m}-\mathbf{A}$ lovely variety, erect feathery growth, bright glossy green. 15c., postpaid.

Aspidium Tussimense "The Bird's Eye Fern"Beautiful finely divided fronds, lace effect; one of the best for table decoration, dishes, baskets and window boxes. 15c., postpaid

Pteris Argentea (Eagle's Claw Fern)-Pea green foliage with silver variegations; grows nicely in pots with other flowers. 15c., postpaid.

The Beautiful Moss Fern (Selaginella Emiliana) -A very pretty and interesting little fern with mosslike foliage, delightful for fern dishes, wardian cases, etc. $15 \mathrm{c}$. each, $\$ 1.50$ per doz., postpaid.

SPECIAL OFFER No. 62-Any 3 varieties for $40 \mathrm{c}$.; set of 6 for $75 \mathrm{c}$., postpaid.

SPECIAL OFFER No. 61

4 above Beautiful Ornamental Ferns, 65c., postpaid, or extra size plants for imme= diate effect, above 4 only $\$ 1.50$, or $\$ 2.00$ delivered free in U. S. A.

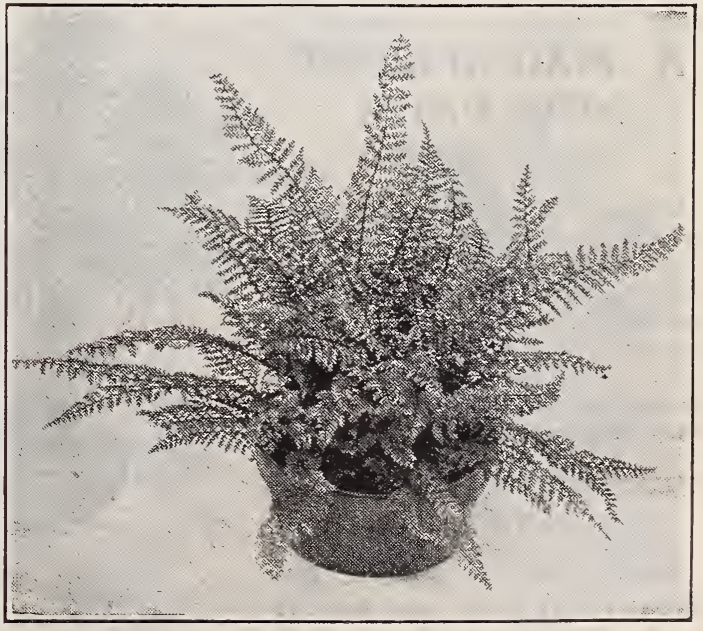

Moss Fern for House or Conservatory 


\section{GRACEFUL AND ORNAMENTAL PALMS EASY.TO GROW AND WILL LIVE FOR YEARS}

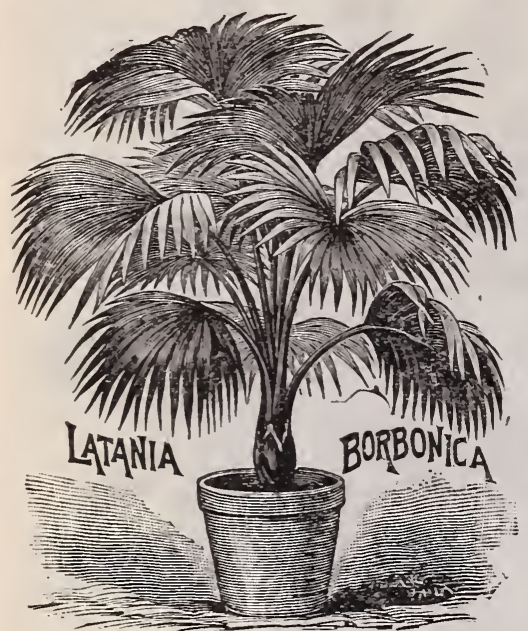

\section{The Fan Palm \\ (Latania Borbonica)}

This is one of the very best Palms for house culture, hardy and will thrive in any ordinary living room, regardless of heat or cold, dust or drought. Has elegant fan-shaped leares, rich dark green, beautifully fringed. Grows easily, needs no petting or coaxing. Fine plants, 6 to 10 inches high, 25c. each; 10 to 15 inches, $35 \mathrm{c}$., postpaid; 15 to 18 inches, 50c. by express.

\section{The Kentia Palm (Belmoreana)}

The Kentia Palm, besides being one of the most graceful and ornamental of all palms for the house or conservatory, is also onc of the hardiest and easiest to grow. It is not affected by the dlist and dry air of the housc, and will grow and thrire where few other plants would live, and will continue to increase in size and beauty for many years. Fine thrifty plants, 6 to 8 inches high, 25c.; larger size, $35 \mathrm{c}$. each, postpaid. Extra size, 50c. each, by express.

\section{Cocos Weddelliana}

This is one of the most elegant and graceful of all the smaller palms; its slender, erect stem is freely furnished with its gracefu arching fronds and fine, deep green leaves. The Cocos is quite hardy and easily grown, and is highly valued as a very choice table and parlor ormament for vases, fern dishes, etc. Nice plants, 6 to 8 inches high, 3 frouds, $30 \mathrm{c}$., postpaid. Larger size, $50 \mathrm{c}$. each, by express.

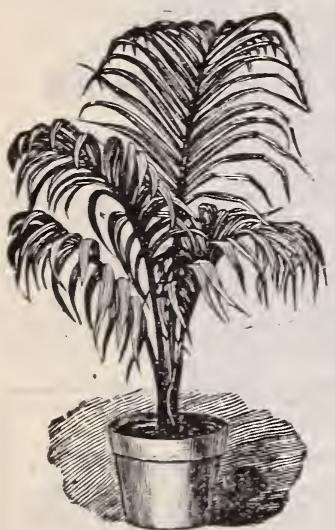

\section{Ostrich Feather Palm} (Areca Lutescens)

One of the grandest and most beautifu plms for house culture now known. 'The foliage is rich glossy green, with bright vellow stems, full of grace and beauts; hardy and easily grown; it grows more beautiful as it grows older and larger. The palms require no special treatment; will all thrive in parlor or living room. Good strong plants, 6 to 8 inches high, 25c. each: 10 to 12 inches, 35c. each, postpaid. Larger plants, $50 c .$, by express.

\section{Umbrella Plant \\ (Cyperus Alternifolia)}

The Umbrella Plant somewhat resembles a palm in general style and habit of growth; grows easily and makes a nice window grnament. Good strong plants, 15c and 20c each, postpaid. Large size, 35c. and $50 \mathrm{c}$. each, by express.

Ostrich Feuther Palm

\section{A MAGNIFICENT NEW PALM}

(Phoenix Roebelini

This splendid New Palm is the finest of all Decorative Plants for house and conservatory culture. It resembles the beautiful Cocos Weddelliana in graceful foliage, but is much more impressive, and is remarkably hardy and ensily grown. I'rice, handsome young Palms, 25̃c. each, postpaid. Larger size, 50c., by Exp.

\section{PLANTS LIKE IT}

Buy a Box of Bonora, the Great Plant Food, and have it handy. $30 \mathrm{c} .$, postpaid.

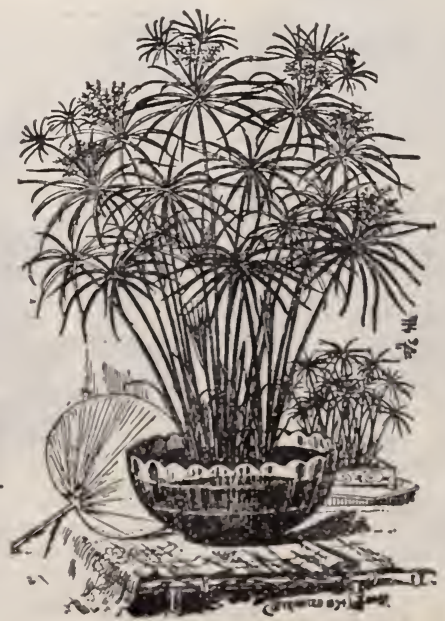

Uinbrella Plant, Cyperus Alternifolla

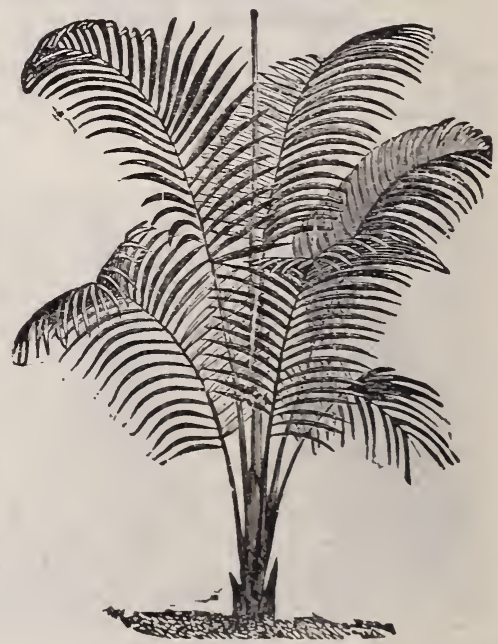

Cocos Weddelliani

SPECIAL OFFER No. 63 63a.-Any 3 Palms, e $x c e p t$ Phoenix, 60c., postpaid.

63b.- Entire 5 Palms and $1 \mathrm{Um-}$ brella Plant, $\$ 1.25$, postpaid. 63c.-Any 3 Palms, larger size, by express, $\$ 1.25$ here.

63d.-Entire 6 above Plants, Iarger size, by express, $\$ 2.50$ here.

\section{Dayton, Ohio, April 15, $196 \mathrm{~s}$.}

CrixARD \& JONES ro. I lave just red ordered a few they are very fine.

rery fine. ete. from you and wish to say they are exactly as represcuted in your catalog. and I am greatly nleased with the way in which you bandle $\mathrm{my}$ orders.

Again thanking you, I remain. Yours truly, MRs. D. L. A- 


\section{The Lovely Christmas Tree Palm}

(Norfolk Island Pine, or Araucaria Excelsa)

This is one of the handsomest and most beautiful of all the decorative evergreens for house culture. It has few equals, but is not often seen because rare and expensive, but we are now in position to offer it at reasonable prices, so that all who wish can hare one of these beautiful trees in their home; it grows nicely in parlor or living room, requires very little care, not subject to insects, stands hard usage well, is exceedingly beautiful, and has a high-bred distinguished appearance entirely different from anything else. Price, fine sturdy little trees, 8 to 10 inches high, 2 to 3 tiers of branches, from 4 -inch pots, $75 \mathrm{c}$. each, postpaid. Larger and heavier trees $\$ 1.00, \$ 1.50$ and $\$ 2.00$ each, by express.

\section{Grand Japanese Fern Balls}

These pretty Japanese Fern Balls are made in Japan from a special variety of mountain fern roots and moss, and are so constructed as to send out beautiful emerald green fronds from every point until covered all over, and are beyond question the most unique and beautiful of all decorative plants. They are easier grown than a palm, and more beautiful; require no potting or soil ; anyone can grow them successfully.

DIRECTIONS FOR STARTING-Soak the ball in tepid water for a half hour, then hang up, repeat every other day until growth is started, after which sprinkle occasionally as required. It may be allowed to dry up at any time when desired, set away and started up again by watering as before.

\section{PRICES FOR FERN BALLS}

\begin{tabular}{|c|c|c|}
\hline Diameter & Delivered Free & By Express, not Prepaid \\
\hline $\begin{array}{l}7 \text { to } 9 \text { inches } \\
5 \text { inches } \\
4\end{array}$ & 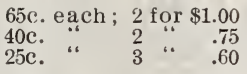 & 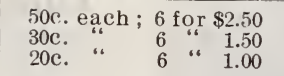 \\
\hline
\end{tabular}

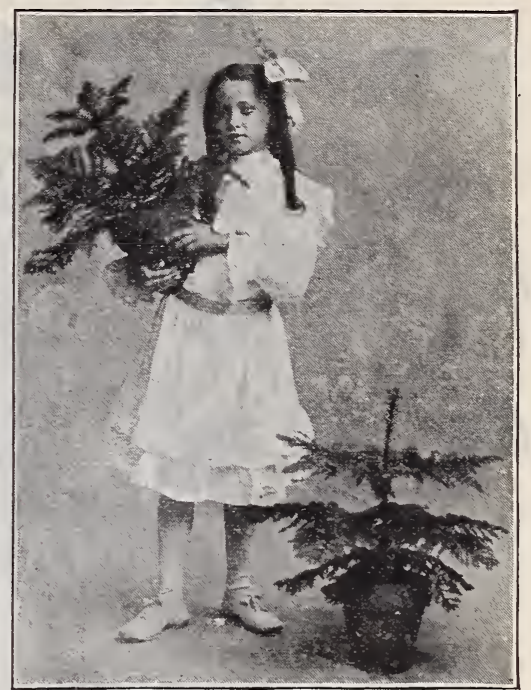

"Christmas Tree Palm"

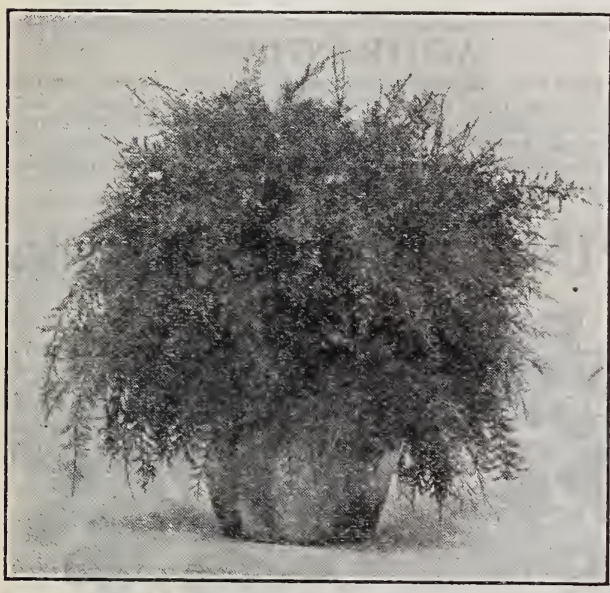

Japanese Air Plant

\section{New Fern "Pteris Wilsonii"}

This is sometimes called the "Crested Fern," and is the most decorative of all the Pteris. It has a handsomely crested form which is just as elegant as a specimen plant as any variety of Nephrolepis, and in a small size is a most desirable variety for fern dishes. Price, 15c. each; larger size, 25c., postpaid. Extra large plants, $50 \mathrm{c} .$, by express.

\section{Japanese Air Plant}

(Also called Sea Moss)

Absolutely no earth, soii, sand or water required; it will thrive and increase in size if simply suspended in midair. Our illustration shows how luxuriant is the growth. Several wellstarted sprays are massed together in a basket. The individual sprays are as light as a feather and fluffy as the finest silk; color a beautiful bright moss green, and no trouble at all to grow. Price, 25c. per bunch, postpaid.

\section{The Rubber Tree (Ficus Elastica)}

Well known as one of the finest plants for porch and parlor decoration. Its large thick olive green leaves and graceful polished stems make it one of the rery finest ornamental plants impunity, and always looks handsome and attractire. Fine

Success with House Plants By Lizzie Page Hillhouse

A complete text-book and.guide to the care, cultivation and propagation of all plants in the garden and the home.

The volume is written by a woman in plain, concise language, easily understood, and the book has the special merit of giving directions which can be readily followed, the methods prescribed being of the simplest, and the material sug. gested to be used easily within reach of all.

$12 \mathrm{mo}, 232 \mathrm{pp}$; profusely illustrated with complete and ready-reference index to all plants enumerated.

Price, Cloth, \$1.00; Paper, soc., postpaid.

SPECIAL OFFER No. 65-The Beautiful Window Garden Collection 6 plants, and book, "Success with House Plants," \$1.50, postpaid. chaser's expense, 50c., $75 \mathrm{c}$., $\$ 1.00$ each, according to size.

\section{Beautiful}

Window Garden Collection

1 Nexport Parlor Fern, .. . . 26 15c.

1 Large Flowering Impatiens, . 32 $15 \mathrm{c}$

1 Heliotrope, 1 Scarlet Fountain Plant, . . . 32 10c.

1 Free Blooming Chinese Prim-

$15 \mathrm{c}$

1 Beautiful Red Geranium, . $32 \quad 15 \%$

SPECIAL OFFER No. 64 - All six plants, to make a nice showing this coming Winter, for $65 \mathrm{c}$., postpaid.

sturdy plants from 4-inch pots, 65c each, postpaid, or by express, at pur-

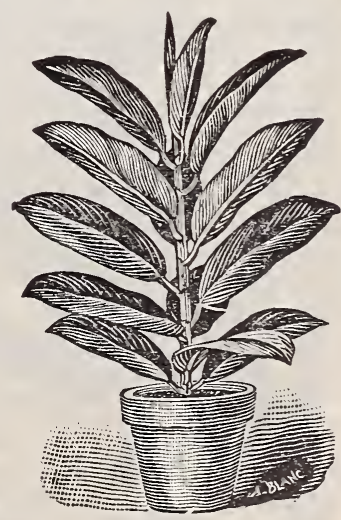

Ficus Elastica 


\section{New Abutilons for House 还 Window Culture}

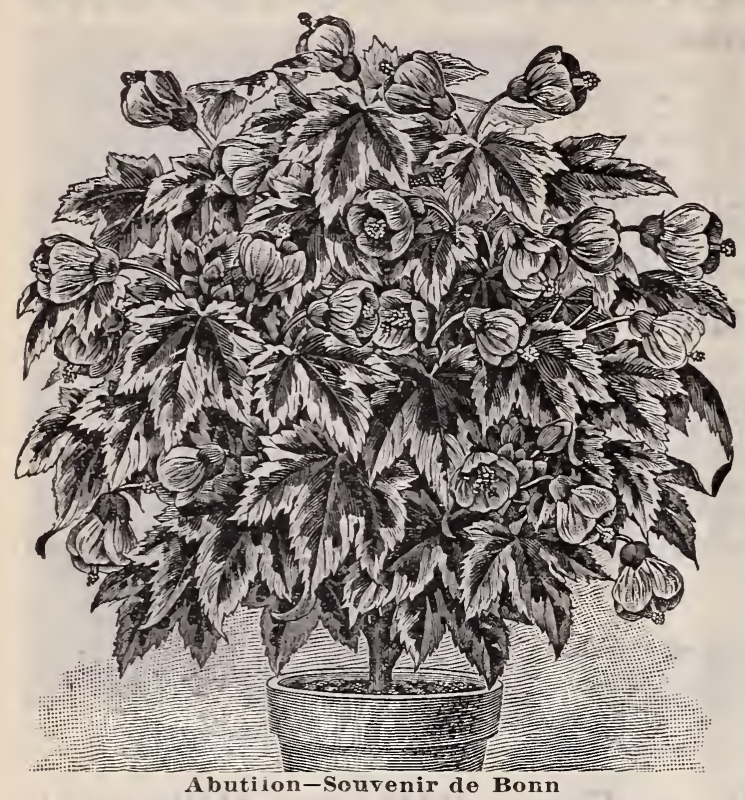

AGERATUMS

New Blue Ageratum (Stclla Gurney)-Finest Ageratum yet produced, neat compact plants, covered all the time with lovely fluffy sky-blue flowers; fine for window garden, also beds and borders. 10c. each; 75c. per doz. New Snow White Agerarum (Whitc Cap)-A fine companion for the Blue Stella Gurney. 10c. each, postpaid.

A. Golden Fleece-Pure deep golden yellow flowers, constant bloomer, and most charming variety for pots, vases or baskets. 15c. each.

A. Mottled Gem-An elegant new variety; pretty milk-white flowers with yellow center and glossy deep green leaves spotted all over with creamy white and yellow. 15c. each, postpaid.

A. Robert George, New-Fine broad cup-shaped flowers with beautiful overlapping petals; color, orange veined with crimson. Very handsome and continuous bloomer. 15c. each.

A. Silver Edged, Souvenir de Bonn - A grand plant for beds and borders; leaves, deep green, edged with creamy white ; large bell-shaped flowers, buff yellow veined with rose. 15c. each, postpaid (see cut.)

A. Splendens, New Crimson-Splendid large, bright crimson flowers, exceedingly bright and beautiful. One of the ncwest and handsomest $\mathrm{Abu}$ tilons yet produced. 15c. each.

A. Thompsonii Plena, New-Rich glossy green leaves spotted all over with deep golden yellow, fine double flowers, rich orange yellow, veined with crimson. 15c. each, postpaid.

SPECIAL OFFER No. 66-The 6 Abutilons for $75 \mathrm{c}$., postpaid.

Comet Plant (Acalypha Sa n d e r i i i)-This inches high blooms quickly and abuudantly and the long flower tassels grow as long as the plant is high; covered all over with fine crimson flowers; grows easily and blooms all the time. 15c., 20c. and $25 \mathrm{c}$. each. postpaid.

\section{BEAUTIFUL FLOWERING BEGONIAS 90c.}

Corallina Lucerna, New - This splendid new variety produces gigantic trusses of from 60 to 70 large flowers of a bronzy red color; blooms constantly from April to November. The foliage pretty, serrated edges. 25c. each. Compta-A charming sort with delicate green foliage veined with silvery lines; under side of leaves red; small white flowers in large clus-

Fuchsoides Coccinea-Resembles Hybrida Multiflora, but with large leaves, and bright scarlet, drooping fuchsia-like flowers, a perpet u a 1
bloomer, highly valued and very beautiful. 15c. Metalica Velutina-Very distinct and different from all others; foliage very dark, rich and velbrown: a beautiful not plant. $15 \mathrm{c}$. each, post Iultiflora Rosea-Makes beautiful plants for nots or bedding, graccful drooping branches, cach, postpaic.

rest. Gaulin-Leaves bronze green, shaded red on under side, pretty pinkish white Howers in large clusters; constant bloomer. 10c. each, Ramosa Picta-A most charming house begonia of neat compact growth; long narrow heartshaped leaves, finc olive green, rich and velvety and spotted all over with shining silvery spots postpaid.

Kubra (The Coral Begonia) - Blonms in large Sandersoni - A beautiful variety; fine coral red heart-shaped buds, constant bloomer. 10c. each.
Wellingtoniensis Alba-Beautiful fern-like foliage and lovely white flowers, bornc constantly

the whole scason in great profusion. 10c. each.

SPECIAL OFFER No. 67-Any 3 10c. kinds for $25 \mathrm{c}$. $315 \mathrm{c}$. kinds for $35 \mathrm{c}$. Set of 10 for 90c. Postpaid.

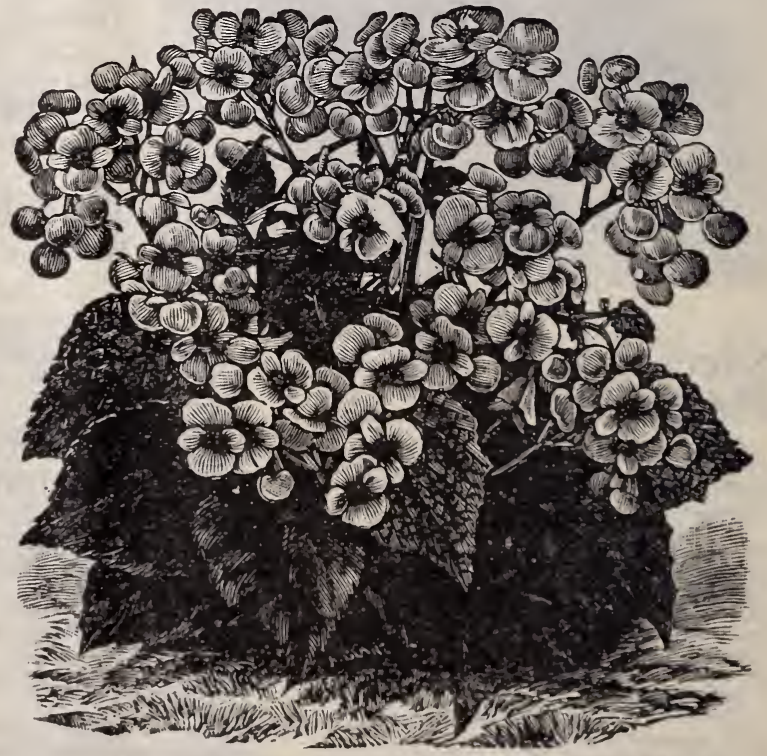

New Perpetual Blooming Begonia Gracilis

TRAILING BEGONIA (Cissus Discolor)

A lovely vining wind ow plaut with cxquisitely colored foliage deep bronze greell witl hright metallic luster. beautifully marked with silver and veined with rich crimson. Likes heat and mois ture, and soon makes a narlor plant of almost unequaled beauty Fine for vases, window boxes, hanging baskets, etc. 10c. each larger size, 15c. postpaid. 


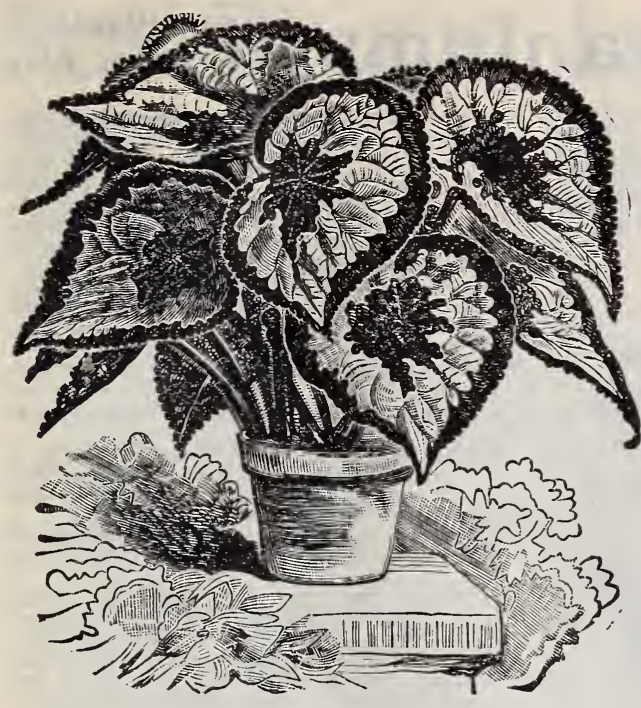

Rex Begonia

\section{The Rex Begonias}

These are among the most beautiful foliage plants there are for house and conservatory culture; they like rich soil and plenty of heat and moisture. They are strong bushy growers, and their grand ornamental leaves are exceedingly beautiful and always greatly admired.

KING OF REX-A grand variety, leaves very large, soft rich velvety green splashed all over with silver marlings, shaded and veined with rose and pink. 15c. each.

LOUIS CLOSSON-Rich, velvety leaves corered with red plush effect, edged with bronze green, and lined with silvery white. 15c. each.

MAGNIFICA - A strong healthy grower, with soft velvety bronze green foliage with silver blotches and nicely veined. 15c. each.

MRS. A. G. SHEPHERD-Rich, velvety leaves corered with red plush effect; edged with green and dotted with white. 15c. each.

SPECULATA-A fine plant with leaves like a grape leaf. They are bright green in color, with a background of chocolate. The veins are of a light pea-green, and the whole leaf spotted with silvery white. 15c.each.

SPECIAL OFFER No. 68 -The above set of 5 for 70c., postpaid.

NEW GIANT FLOWERING BROWALLIA (Violet A charming plant both for the window garden and the flower bed. Makes nice bushy little plants 8 to 10 inches high, and blooms all the time. Large flowers, fully 2 inches across, lovely deep violet blue. No trouble to grow. Strong plants. 15c. each; 2 for $25 \mathrm{c}$.; $\$ 1.50$ per doz., postpaid.

\section{ROYAL PURPLE BOUGAINVILLEA}

CRAB CACTUS - If you want a good sturdy house plant, try the old crab cactus; it bears large rosy crim-

CLERODFNDRON BALFOURII-A lovely vine for window or conservatory, grows 2 to 3 feet high, bears hundreds of beautiful pear-shaped flowers, crimson and white. 15c. each, postpaid.

\section{COLEUS}

New Coleus, Dr. Ross-One of the brightest and richest colored varieties ever sent out; enormous leaves, rich dark velvety crimson, shaded and marbled with black; elegantly fringed and bordered with green and gold. $15 \mathrm{c}$. each ; 4 for $50 \mathrm{c}$.; $\$ 1.50$ per doz., postpaid.

Attraction-Green and red with golden yellow markings ; an erect bushy grower.

Eldorado-Golden yellow, bordered bright green.

Fairy Gem-Round leaf, green, red and yellow.

Hiawatha-Curiously marked with uneven patches of green, dark brown, red and buff yellow, very odd and brilliant.

Rita Kirkpatrick - Deep yellow with red and green markings.

Sensation-Brilliant shades of red and golden yellow.

Verschaffelti-The standard crimson variety.

Price, except Dr. Ross, 10c.; 3 for 25c.; 75c. per doz., postpaid.

\section{STRONG FIELD=GROWN}

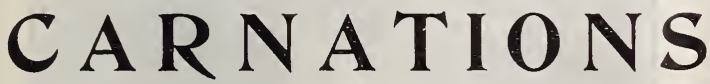

\section{FOR IMMEDIATE BLOOM}

Carnation Pinks are the sweetest and most beautiful flowers you can possibly have for Winter bloom, and it is easy to have them in abundance if you get Our Strong Field-grown Clumps, which are specially prepared for Winter flowering, and will break into full bloom almost as soon as potted, and continue bearing flowers as long as in growing condition. The following are the best varieties for Winter flowering:

Harry Fenn-Of this entire list of carnations Harry Fenn has, perhaps, the richest coloring-a beautiful crimson, with flowers large and full.

Climax - A wonderfully beautiful Carnation, rich salmon pink, prettily fringed and delightfully clove-scented, fine large flowers, well borne up on tall stiff stems, a very handsome and productive variety.

Dorothy-A very handsome variety, a strong, vigorous grower and great bloomer; large, full flowers, rich dark pink prettily fringed and delightfully perfumed; fine both for garden planting and cut flowers.

Flora Hill-Pure white, fine large flowers on long, stout stems.

J. H. Manly-Bright vermilion red, very rich and handsome, elegantly fringed and fragrant, constant and abundant bloomer, fine for cutting.

Queen-The new large flowering, snow-white carnation, which bids fair to be queen of all snow-white carnations yet produced. It is a clear, healthy grower, a most constant and abundant bloomer, the flowers are large, elegantly fringed and richly fragrant.

Yellow Beauty - A rich yellow flower with a light pink stripe, of good size and a vigorous grower.

Price, 20c. each; 3 for $50 \mathrm{c} . ; 7$ for $\$ 1.00$, postpaid. By express, at purchaser's expense, $15 \mathrm{c}$. each; 7 for $75 \mathrm{c} . ; \$ 1.25$ per doz.; $\$ 8.00$ per hundred. 


\section{Choice New Geraniums}

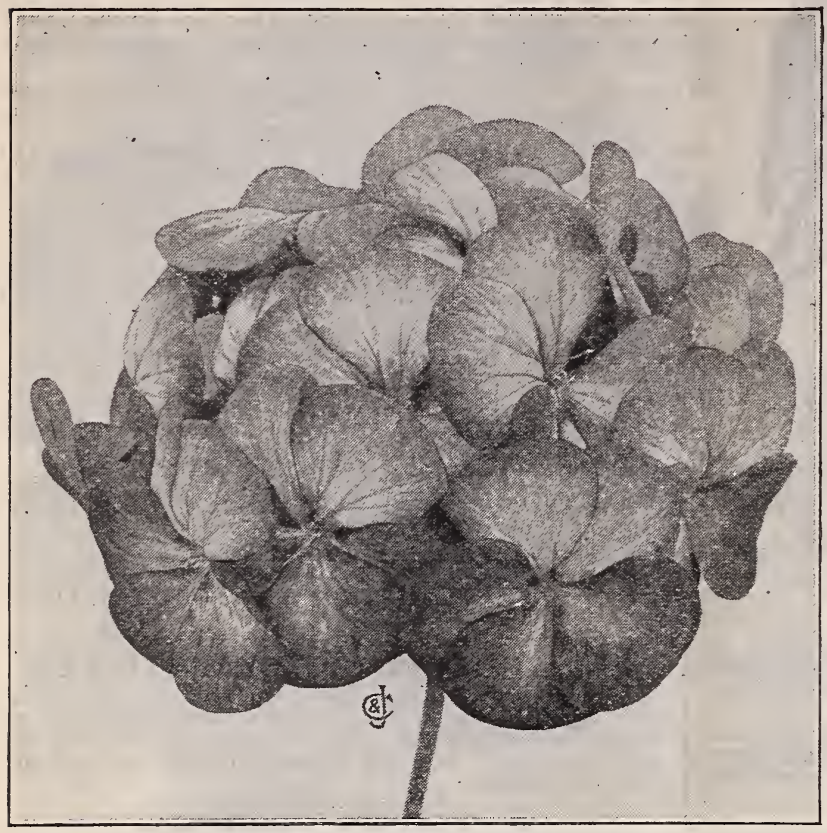

New Geranium "Dryden."

Double New Life Geranium-This is a remarkable novelty. Always scarce and difficult to obtain. The florets are dark red, and in the center of each there appears a small pure white floret, giving the flowers a novel and curious appearance. Very beautiful when flowers are periect, but variable and best for house culture.

Beaute Poitevine-Bright salmon pink, immense trusses, and extra large semidouble florets ; a most constant and profuse bloomer; extra fine.

Bismarck-Rich golden yellow leaves with broad chacolate band on each; rigorous, compact grower; makes beautiful, regular formed plants.

Double Gen'l Grant - Well known as one of the best and brightest Geraniums for bedding; vigorous, compact plant covered with flowers all the time.

La Favorite-Pure white elegant flowers of surpassing beauty, a good healthy grower and free bloomer.

Dryden-A splendid Geranium, one of the largest and finest: color fine glowing crimson shading to white at center. (See cut.) Mrs.J. M. Garr-A standard rariety for all purposes; large pure white flowers not injured by sun or rain; one of the best pure white kinds.

Queen of Crimsons (S. A. Nutt)-This is one of the best dark rich crimson Geraniums; large bold flowers in splendid trusses, borne in great abundance all through the season, one of the brightest and best varieties.

PRICE-Strong Repotted Plants, 15c. each, 3 for 40 c., postpaid.

SPECIAL OFFER No. $69-$ Set of 8 for $\$ 1.00$, postpaid.

\section{CHOICE ,FUCHSIAS (for Winter Bloom)}

Speciosa-The true Winter-blooming Fuchsia; blooms with the greatest profusion during Winter, and is scarcely ever without flowers from September to June. 15c.

Elm City-Sepals rich crimson; corolla deep purple and very double; free flowering and easy to grow. 15c. Esperance-A new and very handsome variety. Extra large flowers, rich purple and crimson; fine bloomer. $15 \mathrm{c}$. Phenomenal - Extra large flowers; tube and petals bright reddish crimson; corolla beautiful violet purple, flamed with scarlet; very double and fine. $15 \mathrm{c}$.

Trailing Queen $-A$ pretty weeping or trailing Fuchsia fine for vases and pots; briglit rich scarlet and purple flowers borne in large graceful clusters; perpetual bloomer. $15 \mathrm{c}$.

SPECIAL OFFER No. 70-5 Fuchsias, 50c. NEW IMPATIENS

" EVENING STAR" -This is a grand plant for pot culture and also for the flower bed; makes nice bushy plant 10 to 12 inches high, covered all over with pretty wideopen flowers, 1 to 2 inches in diameter: pure white with rich crimson center. Very beautiful and blooms all the time. See illustration. 15c. each; 2 for $25 \mathrm{c}$.

IMPATIENS SULTANA-Red flowers, 15c. each, or ? for $25 c$. postpaid.

MIST RESS MARION-A rich purple with scarlet sheen. 15c. each.

ORANGE QUEEN-A brilliant orange scarlct. 15c. each. PORTIA-A charming rose pink. 15c. each.

SPECIAL OFFER No. 71 A-5 Impatiens, 50c.

HELIOTROPES-These arc fine for Winter blooming and very sweet; always greatly admired.

Jersey Beauty and Snow Wreath-10c. each. The 3 for 25c., postpaid.

CAPE JESSA MINE (Gardenia Florida)-A pretty low-growing evergrecn shrub with thick glossy green leaves and waxy whitc double flowers of delicions swectness; hardy in the South, hut here must be kept in cellar or greenhouse over Winter. 20 and 25c. each, postpaid.

PARLOR IVY - A lovely climber for the house or window: grows quickly. 10c. each; 3 for $25 \mathrm{c}$., postpaid.

TRADESCANTIA (Joseph's Coat)-Purple and grcen follage, a traller, fine for vases. 10c. each, postpaid.
FARFUGIUM GRANDE-A rare and beautiful foliage plant, for the house or conservatory, grows low and compact with thick leathery leaves, 8 to 10 inches round, deep glossy green, with large bright yellow spots, rery handsome and striking. Strong plants. 25c. each, postpaid.

GREVILLEA ROBUSTA - (Silk Oak or Fern-Leaf Tree)-An elegant decorative plant for house and conservatory; rapid growth, finely cut foliage, rivaling a rare fern or paim. Strong plants, 10c. and 15c. each, postpaid. Larger size, 25c. each, bv express.

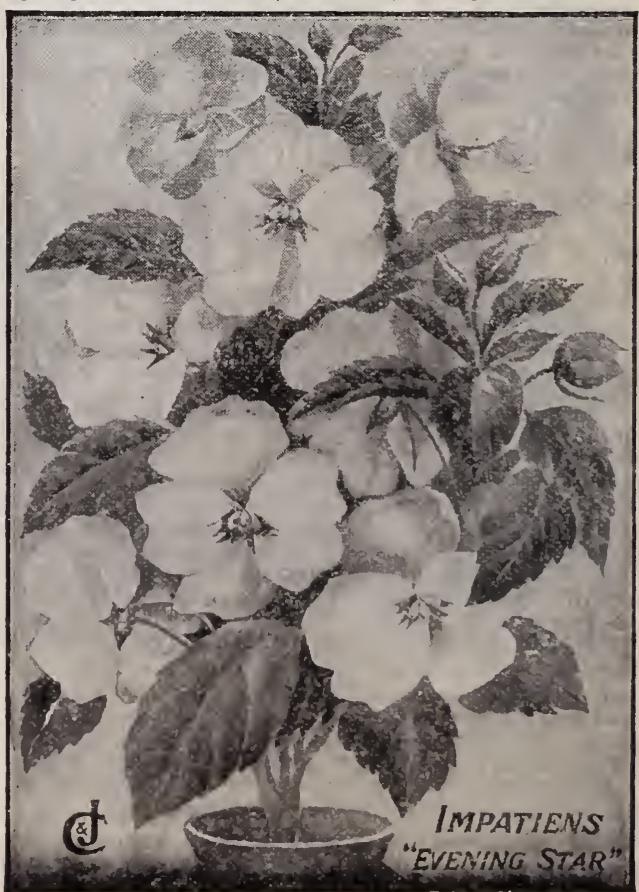




\section{New Weeping Lantana, Mrs. McKinley}

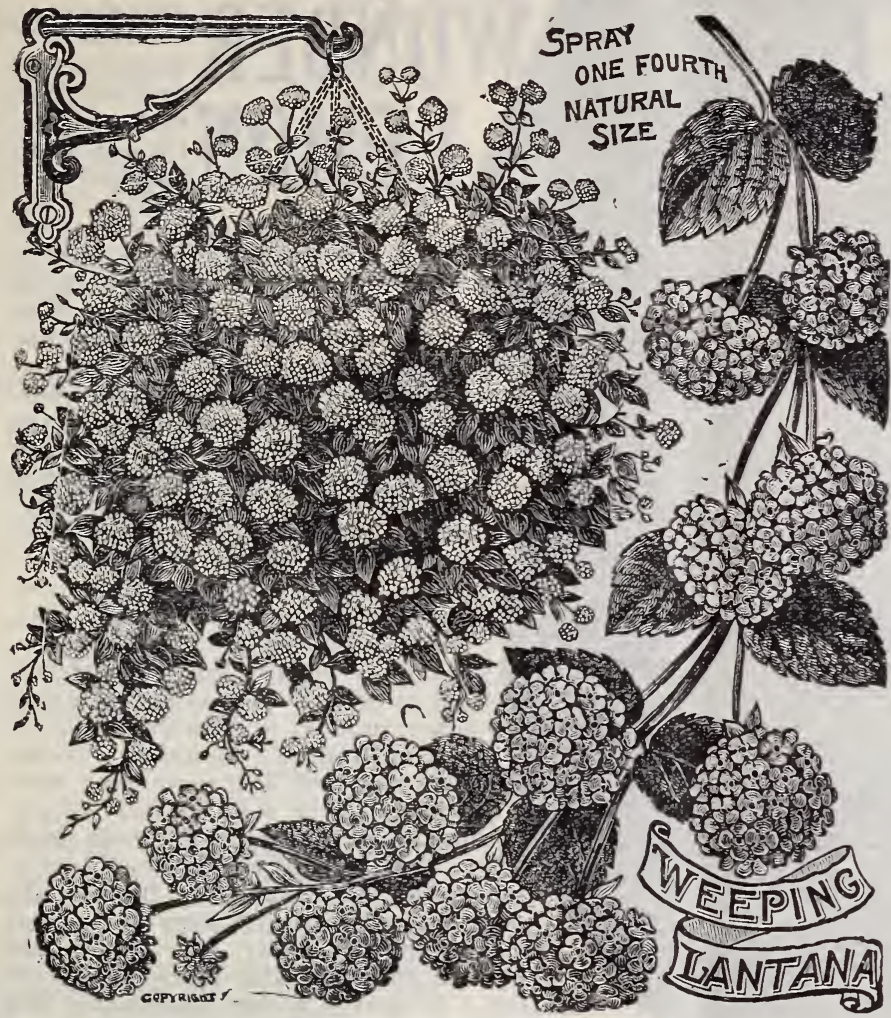

SWAINSONIA - The Swan Flower

Among Winter-blooming plants for house or conservatory the Swainsonias are among the prettiest and most desirable. They have beautiful fern-like foliage and will bloom every day in the year. The blossoms are the shape of sweet peas and nearly as large, and borne in beautiful clusters on long slender branches. It begins to bloom while quite small, and will continue as long as kept in growing cendition. As easy to grow as a geranium; will thrive and house plants do not forget to include the beautiful Swan Flowers. We offer

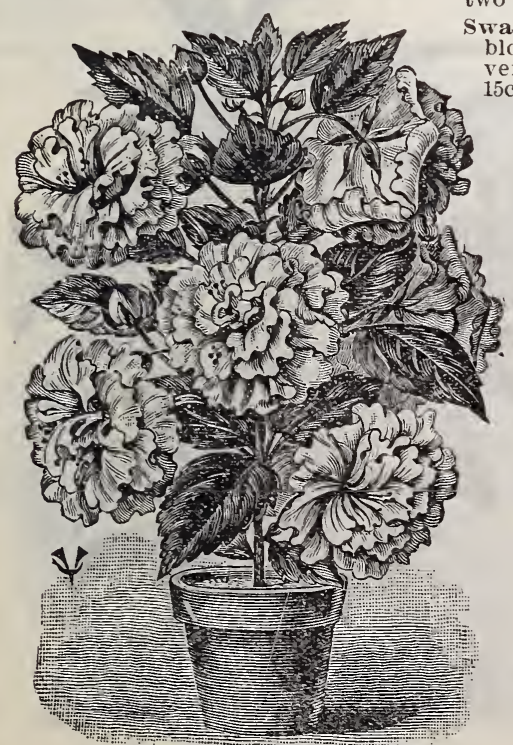

Fiblscus Peach Blow

wainsonia Alba-Large snowy white ( ach ; \$1.25 per doz, posipaid. Swainsonia Rosea - Same as Alba except in color, which is bright rich rosy red. Very hand-

SPECIAL OFFER No. 71 The two beautiful Swan Flowers, 25c., postpaid.

This is a neat trailing plant particularly recommended for Winter flowering in pots; vases and baskets. The flowers are deep lilac pink and borne in clusters. A true perpetual and blooms abundantly as long as kept in growing condition. When Spring comes set out in the flower bed and it will bloom the whole season. Beds of it on our own grounds are covered with flowers for months at a time, and always attract a great deal of attention. It seldom fails to give satisfaction wherever it is put. 15̃c. each ; 2 for 25 c.; 4 for 50 c.; $\$ 1.25$ per doz., postpaid

\section{RUSSELLIA ELEGANTISSIMA}

\section{(Scarlet Fountain Plant)}

A charming plant for pots, vases, window boxes, etc., has long, slender, wiry stems, which grow in graceful drooping masses like flowering hair and covered with pretty tubular flowers of the brightest scarlet color; blooms the whole season, and can be kept in pots Summer and Winter. 15c.; 2 for $25 \mathrm{c}$.

\section{RUELLIA MAKOYANA}

This is a charming indoor plant for culture in vases, pots and baskets. It is of bushy spreading habit with finely marked leaves which are beautiful olive reen, delicately veined with silver, and rich purple underneath. A neat and handsome plant, always bright and pretty. 15c. each; 2 for 25c.; $\$ 1.50$ per dozen.

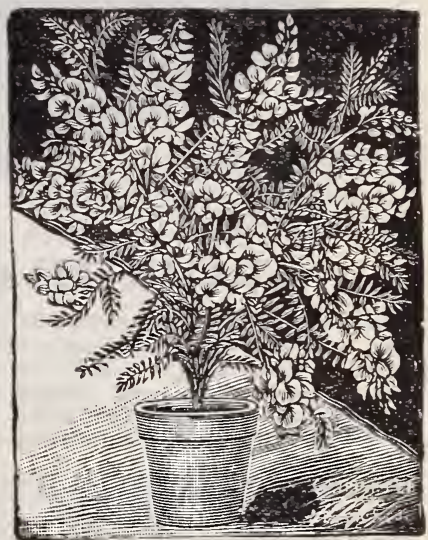

Swainsonia Alba

\section{New Chinese Hibiscus PEACH}

Hibiscus Peach Plow is a truly surprising house plant, the flowers are so immense and yet so beautiful and fragrant that you can scarcely believe that they are not artificial in some way. It is a rapid, erect grower, with bright glossy green leaves and immense double flowers ine roses, 4 to 5 inches in diameter. Color, rich bright pink, with deep quickly ; it can be bedded out in Summer and if taken in before frost will bloom all Winter, too. It is one of the most striking flowers ever seen. Hibiscus Grandiflora-Immense single flowers, 5 to 6 inches around; Hibiscus Violacea-Splendid large towers, soft rosy carmine with riolet shading; very showy and handsome. white, very beautiful and striking.

PRICE SAME FOR ALL-20c. each. Set of 4 for $75 \mathrm{c}$., postpaid ; extra size plants, $35 \mathrm{c}$, , each, or the set of 4 for $\$ 1.25$, express. 


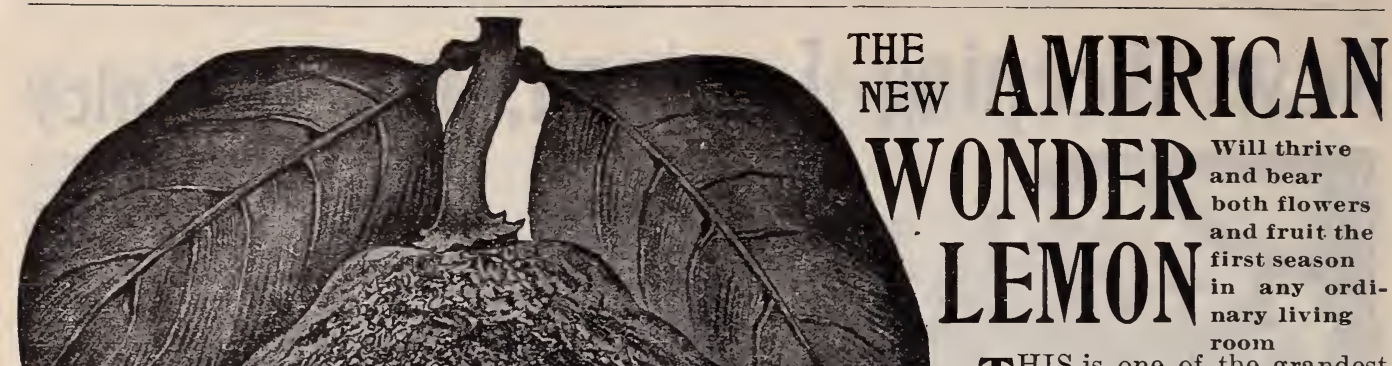

THIS is one of the grandest new fruits for house culture ever introduced. Hundreds of testimonials have been received from persons who have tried it, testifying to its easy culture, wonderful productiveness and the enormous size and excellent quality of the fruit, some of which weigh as much as three pounds each, and are three times the size of the cut shown herewith. It is claimed by the introducers that one of these lemons will go as far as six ordinary lemons for all kinds of culinary uses. The tree is a strong, vigorous grower and quite hardy; may be kept in a pot or box. Set out in Summer and taken indoors in Winter; requires no coddling, not troubled with insects, and will begin to bear very quickly, and as soon as fully established will continue to bear both flowers and fruit continuously every month in the year. The flowers are pure waxy white and very sweet and like orange blossoms; the leaves are thick glossy green and shine as if varnished. It makes a very handsome tree and is well worth taking care of, as it will last a lifetime and grow more valuable every year.

New Lemon

American Wonder

Nice mailing plants, 20c. each; 3 for 50c. Larger size, 25c.; 5 for $\$ 1.00$, postpaid. Fine two and three-year trees, ready for fruiting, 50c., 75c., and $\$ 1.00$ each, express only.

\section{OTAHIETE ORANGE}

This beautiful dwarf orange is one of our prettiest house plants, thick glossy green leaves, and deliciously sweet pure white flowers. Begins fruiting quickly and bears flowers and small golden oranges all the year round. Easily grown and requires very little care. 15c. and 25c. each, postpaid. Larger size, 35e. and 50e. Bearing size, $75 \mathrm{e}$. and $\$ 1.00$, by express.

Oleo Fragrans (Sweet olive)-An elegant house plant grown in profusion aind so fragrant they will perfume the whole house for months at a time. $25 \mathrm{c}$., postpaid; larger, 50c., by exp.

0leanders Fine hard-wooded house plants highly valued for WHITE-Large, snow-white blossoms, very double and sweet.

PINK-Large blossoms, fine rosy pink; very beautiful.

YELLOW-Large flowers ; very sweet and handsome.

Price, 25c. each; the above 3 Oleanders, pink, white, and yellow, for 6isc., postpaid.

The Catley or Strawberry Guava A luscions fruit, highly valued in the South for making sweetmeats. $15 \mathrm{c}$. and $25 \mathrm{c}$. each, postpaid.

Golden Star 0xalis (ortgiesi)-A charming house and bright yellow star-shaped flowers. 15e.

Sanseveria Zealanica A beautiful house plant, grows beautifully barred white and grcell. $15 \mathrm{c}$. to 2 feet high, leaves

Sanchezia Nobilis A beautiful decorative plant for the high, leaves exquisitely veined with erimson and gold. $15 \mathrm{c}$.

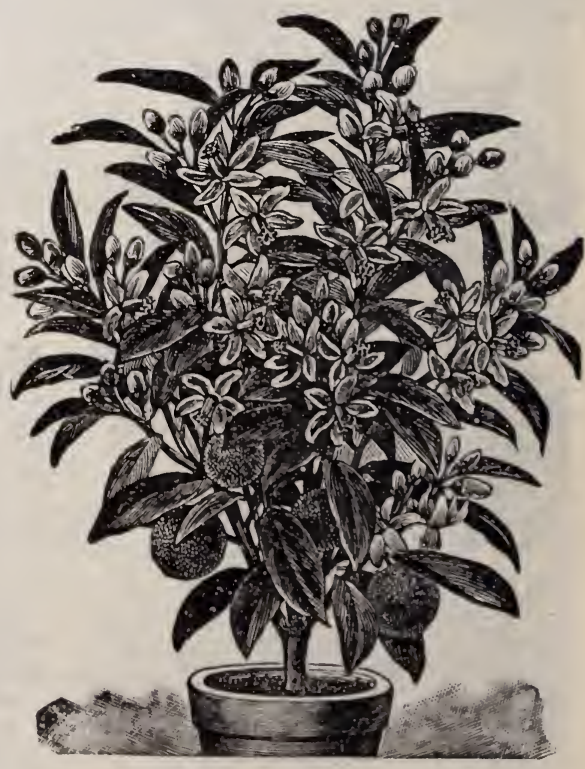

Dwarf Otahiete Orange 


\section{PRIMROSES}

\section{Fringed Chinese Primrose ( ${ }^{\text {Primula Sinensis }}$ Fimbriata}

These beautiful Fringed Chinese Primroses are well known as among the most beautiful and satisfactory plants for house culture and Winter bloom. They will thrive and bloom beautifully all Winter and Spring, in any ordinary window, even where there is not much light or heat and with very little attention. We send strong, vigorous plants, ready for quick bloom. Four separate colors - Pink, Pure White, Crimson and Blue. paid. Larger size, $25 \mathrm{c}$. each; 4 for $75 \mathrm{c}$. , or in mixed colors, $15 \mathrm{c}$. each; $\$ 1.25$ per doz.

\section{Everblooming ( $\left.\begin{array}{c}\text { Primula obconica } \\ \text { Grandiflora }\end{array}\right)$}

This is a grand plant for house culture, grows 8 to 10 inches high and bears splendid clusters of lovely flowers the whole season. They come in many different shades of white, pink and rose. Strong plants, for quick bloom, 15c. each; 2 for 25c.; \$1.00 per doz., postpaid.

\section{New Baby Primrose ( $\left.\begin{array}{c}\text { Primula } \\ \text { Forbesi }\end{array}\right)$}

This is one of the prettiest and most dainty flowers for house culture ever introduced; begins to bloom almost as soon as planted, and will continue throwing up its lovely rings of rosy pink flowers for 8 or 10 months; will thrive in any ordinary living room and does best in a rather cool place. $15 \mathrm{c}$. each; 2 for $25 \mathrm{c}$., postpaid.

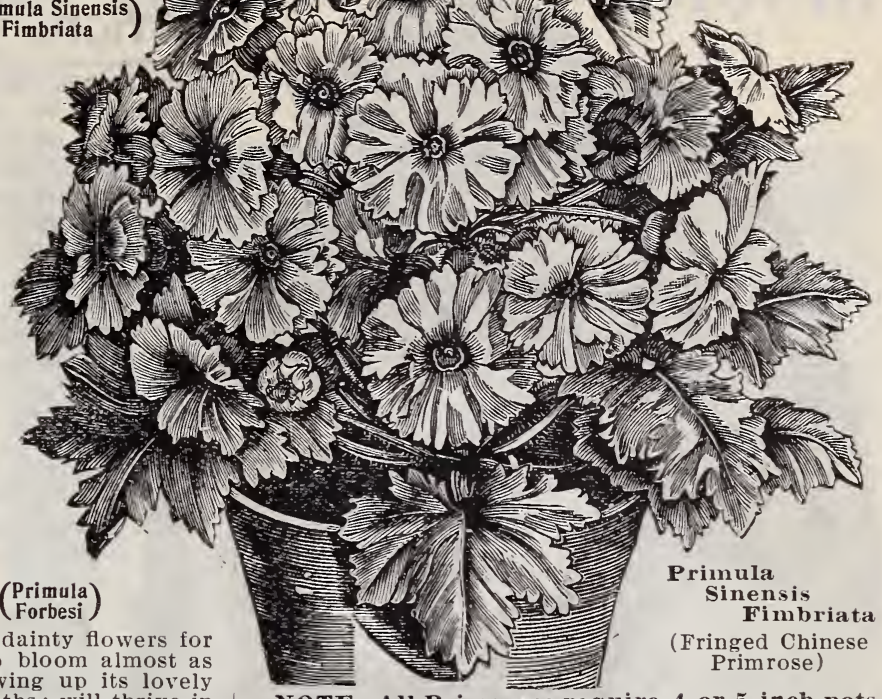

NOTE-All Primroses require 4 or 5 -inch pots and $\operatorname{cood}$ rich earth, and when kept in a moderately cool room will bloom nearly all the time. SPECIAL OFFER No. 72-3 above, 40c., postpaid

\section{SOME CHOICE FLOWER SEEDS FOR AUTUMN SOWING}

The most of these seeds we offer are for planting in pots and boxes indoors, for Winter and Spring bloom. Many handsome window gardens are grown entirely from seeds.

Abutilon, or Chinese Bell Flower-(See page 30). (Hollyhock, Mammoth Allegheny - Finest mixed. Pkt., 6c.

Alyssum, Sweet-Grows easily. Pkt., 3c.; oz., 25c. Aquilegia, Improved Hybrids-Hardy. Pkt., 6c. Aster (Hardy Alpine)-Pkt., 6

Begonia Hybrida-Finest colors mixed. Pkt., 6c. Begonia Vernon-Coral red with yellow center. Pkt., 6c. Begonia Vulcan, or Scarlet Vernon, Intense Scarlet - Pkt., $6 c$.

Calceolaria Hybrida-Large flowering, mixed. Pkt., 10c. Candytuft, Hardy -A hardy perennial. Pkt., 6c.; oz., 25c. Carnation, Marguerite-Fine early bloomer. Pkt., 6c. Cineraria Hrbrida-Finest colors, mixed. Pkt., 10c. Cobea Scandens-Choice climbing vine, Pkt., 5c. Cyclamen Giganteum-Mixed colors. Pkt., 10c

Dianthus Plumarius-Double mixed Pheasant's Eye. Pkt., 5c.

Gloxinia Hybrida-Fine mixed. Pkt., 10c.'

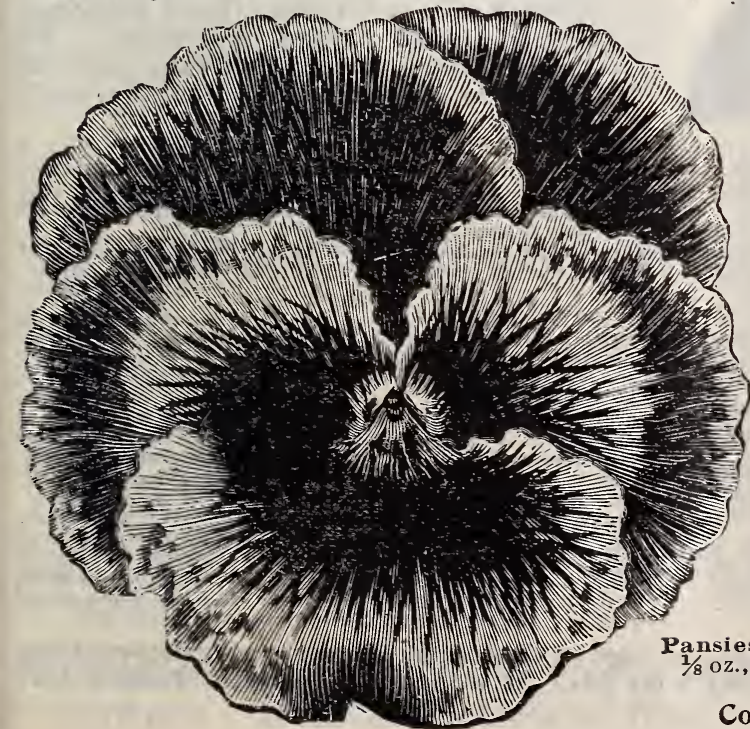
Pkt., 6c.

Mimulus Moschatus (The Musk Plant) - Pkt.

Nasturtium, New-Large flowering dwarf. There are few flowers equal to Nasturtiums; for pot culture and Winter blooming they are superb. Pkt., 5c.; oz., 10c.

Poppy Oriental-Intense dazzling scarlet. Pkt., $5 \mathrm{c}$

Poppy Iceland-Entirely hardy. Pkt., 50.

Phlox Decussata (Hardy) -Pkt., 10c.; $1 / 4 \mathrm{Oz}, 50 \mathrm{c}$

Primula Sinensis Fimbriata (Fringed Chinese Primrose) - Large flowering, splendid mixed. Pkt.,

Primula Obconica - A profuse flowering Primrose, flowers pure white shading to lilac, fine for Winter bloom. Pkt., 6c.

Primula Vulgaris (Hardy English Primrose)-Canary yellow. Pkt., $8 \mathrm{c}$.

Sweet Peas, C. \& J. New Large Flowering-Finest mixed. Pkt., 100 seeds, 5c.; oz., 8c.; $1 / 4$ lb, $15 \mathrm{c}$.

Pansy Seeds are planted largely in the Spring bloom, and we offer the best kind for this purpose.

Pansy, New Giant Ruffled Masterpiece-A re markable new type of giant five-spotted pansies, having ruffly or curled edges. Comes in many beautiful colors. Pkt., 150 .

Pansy, C. \& J. Gold Medal Perfection-A selection of large flowering and fine colors. Pkt., 10c. $1 / 8$ oz., $75 \mathrm{c}$

Pansy, Madame Perret-Flowers of gigantic size and exquisite colorings. Finest mixed pkt., 10c.

Pansy, Coquette de Poissy-Rich rosy mauve, shading to white at outer edge. Pkt., 10c

Pansy, Giant Bugnot-Enormous flowers, very rich and rare shades. Pkt., $10 \mathrm{c}$

Pansy, New Tufted or Bedding-Blooms on from year to year; many beautiful colors. Pkt., 6c.

Pansy, New Parisian-Recommended for great size, beautiful colors and exquisite markings. Pkt., 10c.

Imperial German, Splendid Mixed-More than 50 different shades and colorings of the finest Ger man pansies. Pkt., 150 seeds, 8c.; 1/8 oz., 50c.

Conard's Sunshine Pansies-Bright rich colors, very handsome. Pkt., $5 \mathrm{c}$

es, Good Quality Mixed for Bedding-100 seeds, $5 \mathrm{c}$. Complete Set of 10 Pkts. of Pansies, 50c. 


\section{Grand New Winter-Blooming Roses} NOTICE. Best Roses in America.'" Roses are our great specialty. We grow them by the hundreds of thousands, and offer in our Spring Guide, issued in January, all the newest and choicest varieties in one, two, and three-year sizes, but in this, our Autumn Guide, we offer only short lists of the best Pot Roses in two different sizes for Winter bloom in the house or conservatory, and a selection of the finest two and three-year Hardy Dormant Roses for Fall and early Spring planting in the open ground (see p. 38). When Spring comes and you are done with Roses in the house and conservatory, they can be planted at once in the garden or flower bed, where they should bloom all Summer and Fall. These are all choice well-tried sorts and good for either house culture or garden planting.

\section{Please Remember that these Roses are all $\mathrm{s}$ tr $\mathrm{ong}$} repotted plants, in best condition to bloom quickly and give plenty of lovely buds and flowers all Winter. But it is better to have them shipped by express, so the earth can be left on the roots. Purchaser pays ex= pressage, postage is paid by us.

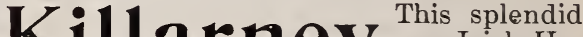

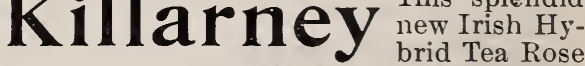
created a mild furore when first introduced a few years ago, and has certainly come to stay. It is a strong vigorous grower and perfectly hardy, having stood out here during the past two Winters without protection. There is no rose we know in this class that blooms more freely than Killarney, and the large size of the flowers and substance of petals are remarkable, petals often measuring $2 \frac{1}{2}$ inches deep. The buds are large, long and pointed. The color is exquisite, a brilliant imperial pink, almost sparkling, and beautiful beyond description. We have a splendid stock to offer this year and all on their own roots. Price, 25c. each, $\$ 2.50$ per doz., postpaid.

Bon Silene - One of the "old Reliables," especially noted tor the great size and beauty of its buds; bright. rich rosy crimson. $15 \mathrm{c} .$, postpaid.

Florence Pemberton-A new rose which has captured gold and silver medals in Europe and America. Flowers are creamy white, suffused with peachy pink, of beautiful form, large, full and double. 15c., postpaid.

Helen Gould-One of the most valuable of the Hardy Crimson Ever-blooming Roses. Flowers arc extra large, nerfectly double, deliciously sweet; color, rich vinous crimsol. 15c., postpaid.

Isabella Sprunt-Flowers of bright canary yellow, buds are remarkably fine, a constant and abundant bloomer. 15c., postpaid.

Kaiserin Augusta Victoria-This grand rose is still unsurpassed in beauty. Extra large, finely formed flowers, very sweet; color, pure white shading to lemon: a free bloomer. 15c., postpaid.

M'lle Cecile IBruner-It has larger flowers than inost of the Fairy Roses: perfectly double and delightfully swect-scented; color, white delicately tinged with vink. 15c., postpaid.
Princess Bonnie - Bright crimson color, exquisitely shaded and delightfully fragrant; noted for the beautiful color of both flowers and buds. Loaded with flowers the whole season. 15c., postpaid.

Princess de Sagan-A fine new French rose, highly valued for its beautiful buds and exquisite colors flowers bright scarlet crimson, very double and swect. 15c., postpaid.

Safrano-A fine old rose; highly prized for its beautiful buds and handsome flowers. Color, bright apricot yellow, sometimes tinted with rose; very fragrant. $15 \mathrm{c}$. postpaid.

New White Soupert (Schneekopf)-Has the same vigorous habit of growth as Clotilde Soupert. The blosioms open perfectly, showing beautiful cup-shaped petals. waxy white and sometimes tinged flesh-pink. 15c., postpaid.

Wellesley-This splendid rose is a scedling from " Liberty" erosscd with "Bridesinaid;" the Howers a re extra large and full; color, bright clcar rose-pink, reverse of petals silver-rose; a vigorous grower, bearing its flowers on tall, stiff eanes: very frec bloomer. Flowers of excellent substanee and durability. 15c., postpaid.

SPECIAL OFPER No. 73-The above set of 12 (or any 12 choice Winter-blooming Roses, from above $15 \mathrm{c}$. kindsi, $\$ 1.50$, postpaid; or any 6 for $75 \mathrm{c}$. If wanted by express, deduct $25 \mathrm{c}$. per dozen from these prices. 


\section{Finest Roses for Winter Bloom}

\section{IN GREENHOUSE OR CONSERVATORY}

The Roses on this page have been carefully selected for "forcing," or indoor Winter bloom. The florists who make it their business to furnish the beautiful cut roses for receptions and important social functions select from such varieties as here shown.

These plants are well rooted, strong and vigorous; they have been growing in pots measuring 4 inches across the top. When received they should be planted in pots 5 or 6 inches in diameter or planted directly in the soil on greenhouse benches.

\section{Dean Hole ${ }_{\text {(H. T. }) \text {-The late }}^{\text {(Hon }}$} widely known as an enthusiastic lover of roses and as author of "A Book About Roses," now in its 14th edition. We believe he has been fittingly honored in a rose worthy to bear his name. The flowers of the rose Dean Hole are large, of great substance and fine form; color, silvery carmine shaded salmon, absolutely distinct and by far the finest in its way of color.

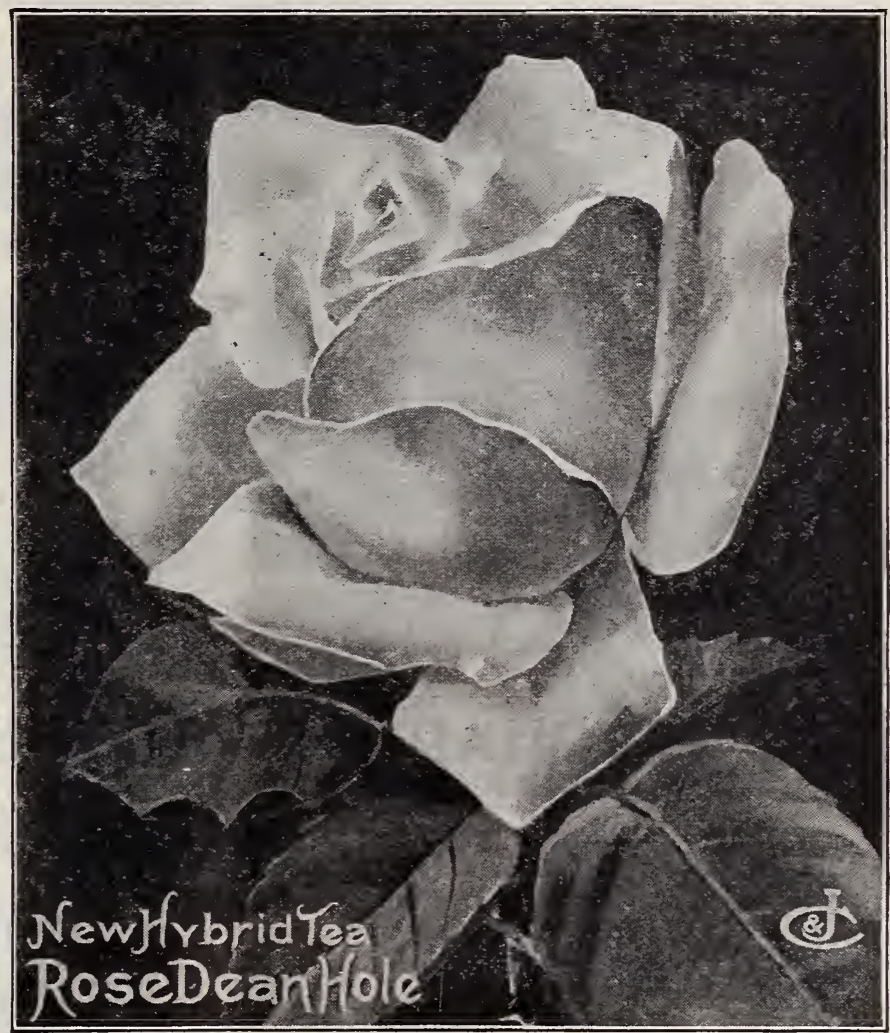

Note with what exquisite beauty the petals are formed

\section{Etoile de France (Star of France)}

One of the most magnificent new roses introduced in the past few years; it is a strong, healthy grower, quite hardy and a quick and abundant bloomer; makes beautiful large pointed buds and extra large fully double flowers, $3 \frac{1}{2}$ to $4 \frac{1}{2}$ inches across. Color, intense brilliant crimson; very fragrant.

KA I S ERIN AUG. VICTORIA-(See description, opposite page.)

KILLARNEY - (See description, opposite page.)

L I B E R T - Deen bright crimson scarlet, beautiful buds; very fragrant; fine for house culture and cut flowers.

MAD. ABEL CHATENAY-A rare and very beautiful rose of novel and distinct color: rich golden pink or rose, flushed with orange and fawn; flowers large, well filled and very fragrant; quite hardy and free bloomer.

MAD. CAROLINE TESTOUT-A grand rose with large full flowers and handsome buds closely resembling La France, but clear cherry red, finely edged with silvery rose; an abundant bloomer.
MAD. JULES GROLEZ-A new rose of great beauty very handsome buds and large, full, finely formed flowers; the color is lovely china rose passing to clear rich satiny pink.

PINK MAMAN COCHET-This a real queen among roses. It is a healthy vigorous grower, the flowers are extra large and delightfully sweet; color, bright coral pink, shading to deep rose; makes lovely buds and is a constant and profuse bloomer, loaded with buds and flowers as long as kept in growing condition.

PRINCE OF BULGARIA-A grand new Hybrid Tea Rose, which took the first prize at the great Paris Exposition. A very vigorous grower; flowers very full, exquisite rosy flesh color.

PRINCESS BONNIE-Undoubtedly one of the finest and most beautiful hardy ever-blooming roses in cultivation; color, bright rich crimson, exquisitely shaded and delightfully fragrant; noted for the beautiful color of both flowers and buds. It is a quick and constant bloomer, loaded with flowers the whole season.

SAFRANO - (See description on opposite page.)

SOUV. DE PRES. CARNOT-This is a rose of extraordinary beauty, elegant form and delicious fragrance. The color is lovely sea-shell pink, delicately tinted with golden fawn.

PRICE-THESE ARE ALL EXTRA STRONG REPOTTED TWO=YEAR ROSES, specially prepared for Winter flowering. $30 \mathrm{c}$. each; 3 for $80 \mathrm{c}$; any 4 for $\$ 1.00$, or $\$ 3.00$ per doz., by express.

SPECIAL OFFER No. 74-The complete set of 12 , only $\$ 3.00$ by express; or $\$ 3.50$ delivered free. 


\section{Large Hardy Field-Grown Roses}

\section{Specially Suited for FALL PLANTING in the Open Ground}

Fall Planting Pays. If you will take "Time by the forelock" and plant your rose bed this Fall you can have flowers a-plenty next Spring. Many people know about this and there is a constantly increasing demand for Hardy Koses for Fall Planting. We are glad, therefore, to make this special offer of extra large, heavy field-grown plants, all properly pruned and ready for delivery as soon as the wood is thoroughly ripened, whieh is usually early in November. 'These varieties have been selected with the utmost care. First-class Hardy Rose Bushes. They

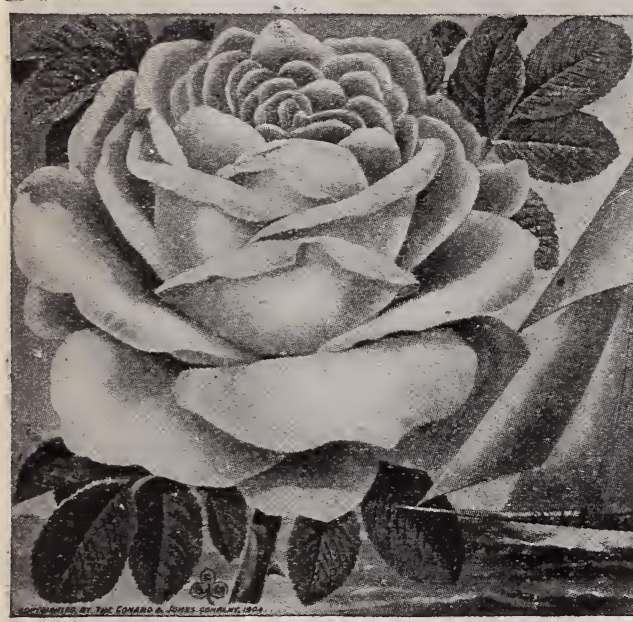
may be planted any time before the ground freezes hard; give the soil about the roots a light proteetion over Winter. Order early and perhaps we can give you other plant suggestions that will prove valuable. Roses wiil be sent as soon as sufficiently dormant to transplant safely.

\section{IRON=CLAD EVER=BLOOMING RUGOSA ROSES}

\section{SIR THOMAS LIPTON (or White Century)}

The finest pure white Hybrid Rugosa Rose yet produced: makes a handsome bush 4 to 5 feet high and bears large double pure white roses all Summer and Fall. It is one of the hardiest roses in existence. It is especially recommended for cold climates and exposed localities, and because of its handsome appearance, perfect hardiness, and wonderful freedom from inseets, rust and disease, it is being used in great quantities (see illustration). Price, two-year bushes, 50c. and 75c. each. Extra three-year bushes, $\$ 1.00$ and $\$ 1.50$ each ; $\$ 5.00, \$ 7.50, \$ 10.00$ and $\$ 15.00$ per doz., by express.

\section{NEW CENTURY (Pink)}

This magnifieent new rose is perfectly hardy and blooms through Summer and Fall. Flowers are exquisite rose pink, full and double, 3 to 4 inehes across and borne in clusters. Foliage like the Rugosa's; rough, shiny, and proof against insects, rust and blight. Valuable, espeeially for hardy borders. Price, two-year, 35c. each. Extra size, three or four-year bushes, 50e. eaeh, by express.

\section{New Red Hybrid
Perpetual Rose CHARLES WAGNER Introduced, 1907, by The}

A vigorous growing rose with large double flowers of clear bright red (approaching scarlet). Blossoms appear in clusters of three to five, of great substance and exceedingly fragrant. It has luxuriant foliage, usually composed of seven leaflets, of dark rich green and not liable to mildew. It is one of the best bloomers and is rery hardy, and therefore particularly desirable for localities where best dark Hybrid Perpetual varieties are sometimes Winter killed. Price, two'year size, 50e.; extra large size, 75c., by express.

\section{CHOICEST H. P. ROSES}

The White American Beauty (Frau Karl Druschki) - New snow-white hardy hybrid perpetual rose. Without exception we believe the most magnifieent white rose in this elass. Enthusiastic praise for it comes from all sides and deservedly so. Pure white, of beautiful form, and petals of such thick substance that the flowers, when cut, will last for days. A healthy, vigorous grower, entirely hardy, and a constant and abundant bloomer. Large two-year-old plants at $\$ 1.00$ each,

Anna de Diesbach (Glory of Paris)-Brilliant crimsonmaroon; extra large, very full and sweet; an excellent bloomer.

Duchess de Caylus-Deep rich crimson, large full perfect flowers, very double and fragrant; grows vigorously and blossoms freely.

Francois Levet-Unusually strong, vigorous grower large round stately flowers; color, bright rosy crimson. General Jacqueminot-Hardy, early and abundant bloomer; for beauty of form and brilliant intensity of color it is unexcelled.

John Hopper-Hardy and abundant hloomer, solid regular flowers, perfectly double, clear bright rosy pink. Paul Neyron-A magnificent rose, one of the largest and finest of all; clear, shining pink; very double.

Prince Camille de Rohan-Very dark, velvety crimsoll, almost black; darkest of all.

Magna Charta-Extra large, full flowers of unusual depth and substance; bright rosy pink, very grand, profuse bloomer; one of the hardiest and best bloomSPECIAL OFFER No. 75-Above 9 in strong 2-yr.=old plants, for $\$ 2.75$, express here.

\section{MISCELLANEOUS ROSES}

Rugosa Alba-Came from Japan. Single pure white flowers of five petals and highly scented, followed by pretty berries.

Rugosa Rubra-Flowers, bright rosy crimson. Two above two-year size, 60c., by express.

Harrison's Yellow-Bright clear golden yellow, entirely hardy. Grows 3 to 4 feet high. Flowers early. 'I'woyear size, 40c. each, $\$ 4.00$ per doz., by express.

Purpurea Rubra (Moss) - Violet purple, l a r g e full flowers, very double and fragrant, nicely mossed. One of the best.

True English Sweet Briar (Rosa Rubiginosa)-Young growth, delightfully fragrant; flowers, bright pink and single (good for groups, hedges or pretty lawn speci-

mens), two-yr. size, $40 \mathrm{c}$ each, $\$ 4.00$ per doz., by express.

York and Lancaster-The beautiful hardy striped rose noted for its large beautifully striped flowers and perfect hardiness. Pink and crimson. Strong two-year dormant plants, 75c. and $\$ 1.00$ each, by express.

The Ever-13looming Baby Rambler, "M a d a me Norbert Levavasseur" -Now becoming well knowi as one of the best hardy bedding roses in existence. Remarkable for abundance of continuous bloom; color, deep rose to bright rea ; a healthy, vigorous grower.

Madame Plantier-Is one of the hardiest of all hardy roses, vigorous grower, making handsome upright bushes, sure to be covered with lovely snow-white flowers every season without attention.

Alice Aldrich-A Rugosa with large double flowers of clear bright pink; an exceedingly sweet and beautiful ever bloomer. Two-year size, 50e., by express.

SPECIAL OFFER No. 76-Above 9 in strong 2 -yr.-old plants, for $\$ 3.25$, express here.

NotE-We nack as light as safety of plants permits and guarantee them to reach you in good condition. Customer pays. express charges, whieh on plants is about 20 ner cent. less than former inerchandise rates, or for a slight addition (see page 39 ), we will deliver these roses free to any express or post office in the United States. Customers who have heen troubled with heavy express charges should take advantage of this offer.

Price for above (except where noted), 35c. each, 6 for $\$ 2.00,12$ for $\$ 3.50$. SPECIAL OFFER No. 77, set of 19 for $\$ 5.50$; or including “Lipton" and "New Century," 21 for $\$ 6.00$, by express. 


\section{Hardy Ornamental Dormant Shrubbery} We recommend these for Fall Planting in the Open Ground. (Ready Nov. 1st)

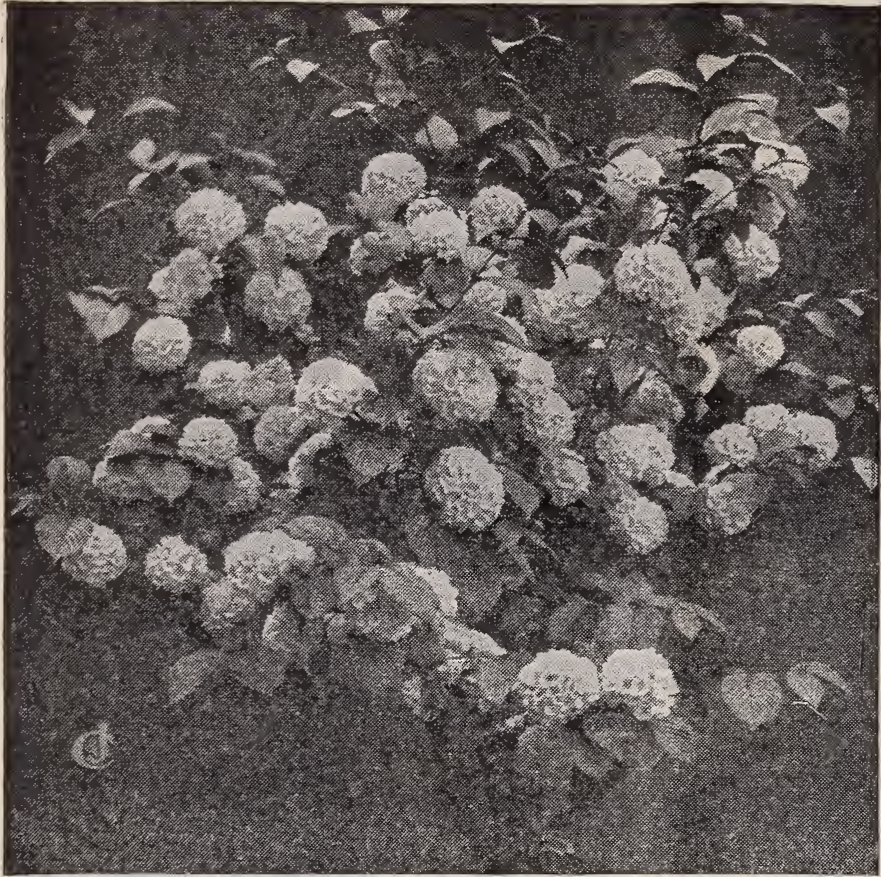

Viburnum Plicatum, Japan Snow-ball. (A small bush on our grounds)

New Double Pure White Althea (Jean d'Arc)-Finest and hardiest Double Pure White Althea ever introduced; bears splendid large double flowers like roses, over 3 inches across. Our bed of this Althea won a Gold Medal at St. Louis World's Fair, 1904.

Althea, Double Violet-Large flowers, rich violet blue. Althea, Double Pink - Large double flowers, clear bright pink.

Althea, Double Red-Rosy-red flowers, very handsome.

Althea, Duchess de Brabant-Large double white flowers with red centre.

Deutzia Gracilis-A low-growing compact bushy shrub; perfectly hardy; blooms early in Spring, covered all over with pure wr'te, bell-shaped flowers. Highly valuable for yard, lawn, park and cemetery planting.

Deutzia Gracilis Rosea (New Rose-Colored Deutzia Gracilis) - A very lovely, low growing, hardy shrub; exquisitely beautiful.

Deutzia Lemoini-A grand new hardy shrub in the way of D. Gracilis, but much larger and finer flowers; splendid.

Doutzia, Pride of Rochester-Grows strong and upright, 4 to 6 feet high; Howers very double and full pure white, tinged with blush; borne in great profusion during May and June.

Deutzia Crenata-Double Pink Deutzia, blooms in Junc, Flowers are tinted with rosy white.

Lilaes-Two kinds, white and purple, both hardy and very fragrant.

Philadelphus or Mock Orange-Beautiful, large cupped flowers: blooms early in Junc; flowers fine creamy white and very fragrant.

PRICES, First or mail size, except noted, 15c. each; 5 for 50c.; 10 for 81.00 , postpaid. 2 year each; 6 for $\$ 1.20 ; 10$ for $\$ 1.60 ; \$ 12.00$ per 100 , by express. Extra heavy 3

Two Good Hedge Plants
Spirea New Crimson (Anthony Waterer)-Blooms profusely early in Spring and at short intervals all through the Summer and Fall; rich rosy-red flowers in large clusters; entirely hardy.

Spirea Prunifolia (Bridal Wreath)-Immense bloom. er; pure snow-white double flowers, like little roses, borne in great profusion the whole length of the branches.

Spirea Van Houteii-A splendid new hardy Spirea, one of the most beautiful of all; pure snow-white flowers.

New Japan Blue Spirea-One of the finest blue flowering shrubs in cultivation, makes neat compact bushes 18 inches to 2 feet high; begins to bloom in August and continues loaded with lovely sky-blue flowers till frozen up.

New Spirea Frobeli-Height, 3 feet ; fine crimson flowers, borne in large clusters; hardy and haudsome.

Weigela Rosea-One of the most charming shrubs in cultivation. Lovely large rose-colored flowers, borne in such profusion that the whole bush appears a mass of rosy bloom.

Weigela Candida (White Weigela) - Snow-white flowers in great profusion.

Weigela, Variegated Leaved-Deep green leaves, each one with a wide border of creamy white; flowers blush pink.

Weigela Floribunda-Flowers, small brownish crimsoulubud and opeuiug bright crimsoll, a strong grower and profuse bloomer.

Weigela Eva Rathke-Purplish-red flowers with

\begin{tabular}{l|l|l|l} 
Price by Express & 10 & 100 & 1000
\end{tabular} Privet (California) -Close, ercet-g rowing, hardy shrub, $\left\{\begin{array}{l}1 / 2 \text { to } 2 \text { ft. } \$ 0.75 \\ \$ 4.00\end{array} \frac{1000}{\$ 35.00}\right.$

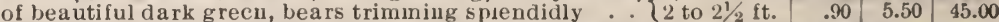
IBarberry Japan (Thunbergii)-A dwarf grower, dark, $\left\{\begin{array}{ll|l|l|l}8 \text { to } 12 \text { ill. } & 1.00 & 800 & 6000\end{array}\right.$

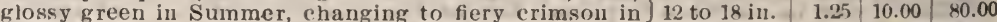
Autumn: one of the most beautiful of all hardy garden 18 to $24 \mathrm{in}$. $1.50 \mid 12.00 \quad 100.00$ shrubs. Plants from original imported stock. 


\section{HARDY PERENNIAL PLANTS, or} 0ld-Fashioned Garden Flowers

Autumn is the best time in the year for planting some hardy perennials. They get well established during the Winter and are ready to start growth with the first sign of Spring. The varieties listed below are among the most economical and satisfactory plants you can buy. They are perfectly hardy and last for years, and thus will save you time, labor and expense and afford a rariety and succession of bloom unequaled.

NOTE-(It pays to spade the ground to a depth of 2 feet to allow for a good root growth; less will do. Enrich the ground generously for best results.)

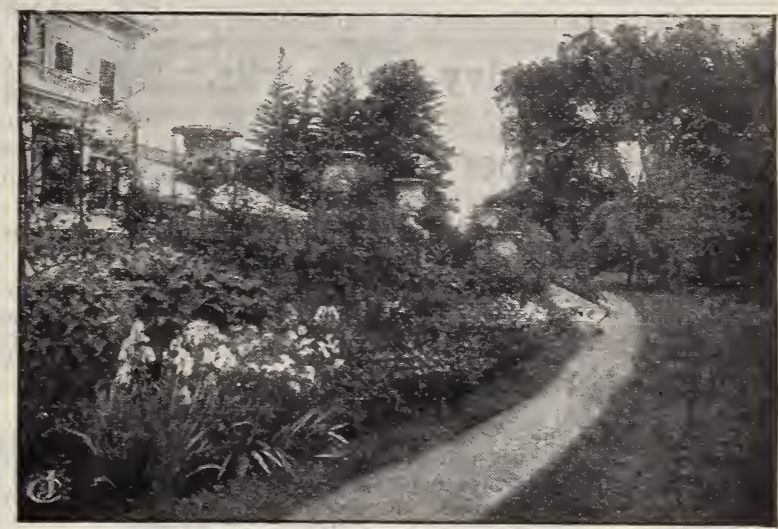

A Hardy Perennial border like this is a satisfaction at all times; blooms freely year after year with little care.

\section{NEW LARGE FLOWERING JAPAN IRIS \\ "Iris Kaempferii Grandiflora"}

Grandest of all hardy Iris. The flowers are enormous averaging from 8 to 10 inches across and of the most gorgeous and exquisite colors.

\section{DOUBLE VARIETIES}

No. 1. Gold Bound-Thite, with gold banded center. No. 2. Blue Danube-Deep blue, with yellow center.

No. 3. Oriole-Deep crimson-amaranth, yellow center.

No. 4. Spotted Beauty-Silky white, spots crimson. SINGLE VARIETIES

No. 5. Skippo-Light lilac, veined with purple.

No. 6. Kumoma - Silvery white, suffused throughout with soft light blue; the largest three-petaled variety in cultivation.

Price on above kinds: $20 \mathrm{c}$. each; set of 6 superb sorts, $\$ 1.00$, or $\$ 1.75$ per doz., postpaid. $\$ 1.50$ per doz. when sent by express.

MIXED SORTS-15c. each ; $\$ 1.50$ per doz., postpaid

ENGLISH IRIS-Large handsome flowers; colors, rich purple, violet and lilac. Height, 18 to 20 inches. Perfectly hardy. Bulbs, 3 for 10c.: 25c. per doz.

GERMAN IRIS-Large crepe-like flowers, sky-blue, yellow, orange and white in beautiful combination. Mixed colors, 6c. each; 50c. per doz., postpaid.

\section{HARDY PERENNIAL PHLOX}

The Improved Varieties of Hardy Perennial Phlox, which we offer below, are among the handsomest and most useful of our hardy herbaceous plants.

Amorite - White and lilac; medium.

August Rererie-Bright red changing to salmon scarlet. Bridesmaid - White with large crimson carmine center. Eclaireur-Purplish crimson with light halo; very large.

Pantheon-The most beautiful pink in cultivation.

The Pearl-Best tall white, beautiful.

Price, $15 \mathrm{c}$. each; 3 for $40 \mathrm{c} . ; \$ 1.50$ per doz., postpaid. Set of 6 for $75 c .$, postpaid.

If you are not particular about colors order Perennial Phlox in mixed rarieties. Price, only $10 \mathrm{c}$. each; $75 \mathrm{c}$. for 10 , postpaid; or $\$ 6.00$ per 100 , by express.

\section{HARDY SWEET VIOLETS}

Violets like plenty of light and air and moderate moisture but not too much heat.

Governor Herrick-Rich dark purple, long stems.

Hardy Double English Violet-Perfectly double and deliciously sweet.

Lady Hume Campbell-Large double blue flowers. California-Enormous flowers, deep violet blue.

Swanley White-The best white violet in cultivation.

Princess of Wales-Single and true violet blue.

Price, nice pot plants, $10 \mathrm{c}$. each; $\$ 1.00$ per doz.; $\$ 7.50$ per 100 , postpaid.

\section{A CHOICE ASSORTMENT OF HARDY PERENNIALS}

Achillea Alba (The Pearl)-Entirely hardy and bears an abundance of pure white, perfectly double flowers, the whole season. 10c. each; 3 for $25 \mathrm{c} . ; 75 \mathrm{c}$. per doz., postpaid.

Aquilegia "Columbine," Variety, "Chrysantha"Height 2 to 3 feet and easily grown. Blooming season, May till August.

Burbank's New Shasta Daisy - Much larger than the old daisy. Does well anywhere year after year.

Coreopsis, Variets, "Lanceolata Grandiflora"-Flowers, rich golden vellow of graceful form, and borne on stems 2 to 3 feet high.

Dielytra Spectabilis or Bleeding Heart-Grand hardy border plant, blooms early in Spring; splendid long racemes of beautiful rosy-pink and white flowers.

Helleborous Niger (or Christmas rose)-Hardy bulbous plants, bearing pure white waxy flowers. If potted early will hloom in December, or early in Spring in open ground; large roots, $25 \mathrm{c}$. each.

New Hibiscus (Crimson Eye)-No trouble to grow, bears immense flowers, six to seven inches across, pure white, with bright crimson center. Dies down every Winter, comes up fresh in the Spring, and blooms the same season. Strong roots, 15c. each; 2 for $25 \mathrm{c} . ; \$ 1.25$ per doz., postpaid. Two-year roots, $25 \mathrm{c}$. each ; $\$ 2.00$ per doz., by express.

Ornamental Grasses (Eulalias) - Perfectly hardy, grows 6 to 8 feet high. Plant singly or in groups. We offer 3 kinds. Graeillima, Zebrina and Variegata. $15 \mathrm{c}$. each, 12 for $\$ 1.25$, postpaid, or clumps, $\$ 1.50$ per doz., by express.

New Tuberous Rooted Clematis, "Platycodon Leichtlinii "-Not a climber, but a low.growing, bushy, herbaceous plant with deep green foliage, and bearing enormous masses of large blue bell-shaped flowers.

New Double Rudbeckia, "Golden Glow"-Grows 6 to 8 feet high. Blooms during July and August the first season, and bears immense masses of large, round, golden yellow flowers, perfectly double and 2 or 3 inches across.

Prices for all above, unless otherwise noted, $15 \mathrm{c}$ each; 3 for $40 \mathrm{c}$; 6 for $75 \mathrm{c} . ; 12$ for $\$ 1.50$, postpaid.

DOUBLE HERBACEOUS PAEONIES

See complete assortment with color plate on first and second cover pages. Prices, 20c. to $75 \mathrm{c}$. each.

SPECIAL OFFER No. 81.-1 Achillea Alba; 1 Columbine "Aquilegia"; 1 Coreopsis; 1 Dielytra; 1 Hibiscus "Crimson Eye"; 1 Platycodon. Above 6 choice Hardy Perennials, 65c., postpaid.

SPECIAL OFFER No. 82.-6 Hardy Perennial Phlox; 6 Japanese Iris; 6 Hardy Violets, as described on this page. Entire 18 with good strong roots, all to be of our selection; $\$ 2.00$ net, delivered free. 


\section{HARDY CLIMBING VINES}

American IVy (Ampelopsis Quinquefolia)fectly hardy and noted for its brilliant colored foliage in Autumn. Two-year vines, 30c.; $\$ 3.00$ per doz.. postpaid. Hardy English IVy (Hedera Helix) - The green climbing vine, with dark glossy green leaves. Large size, 25c. each; $\$ 2.50$ per doz., postpaid.

Trumpet Creeper (Mammoth Flowering A splendid climbing vine, will grow 10 to 15 feet in a season, and through July and August it bears immense quantities of great orange red, trumpet-shaped flowers. $35 \mathrm{c}$. each, postpaid. Large size, 50c., by express.

Akebia 0uinata - A rare and beautiful hardy age and curious chocolate-colored flowers; delicious fragrance. Two-year size, 30c.; $\$ 3.00$ per doz., postpaid.

Chinese Matrimony Vine Bright rosy purlowed by brilliant scarlet berries; makes a dense thick growth, a nice shelter for birds. Two-year size, 25c.; three-year size, 40c. each, by express.

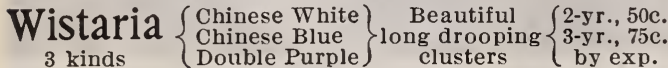
SWEET=SCENTED HONEYSUCKLES

New Ever-Blooming Sweet-Scented Honeysuckle Heckrotti-Flowers very large and deliciously sweet, dark rich red and creamy yellow.

Halliana (The Improved Sweet-Scented Honeysuckle) - Buff yellow passing to white.

Red Coral Honeysuckle-Flowers deep coral red.

Evergreen Sweet - Scented Honeysuckle - Delightfully sweet; flowers creamy yellow and white.

Golden-leaved Honeysuckle-Leaves be a tif ully veined and netted with clear yellow; flowers yellow. Price, 15c. each; 4 for $50 \mathrm{c}$. Complete set of 5 for $60 \mathrm{c}$. , postpaid. Two-year Honeysuckles, all above varieties, large strong bushes, 25c. each; \$2.25 per doz., by express.

\section{CHOICE GARDEN FRUITS}

Every person who has a garden needs some of these Choice New Garden Fruits ; they take very little room, come into bearing quickly, and will repay their trifling cost many times over in delicious fruit, besides the pleasure and satisfaction of having them of your own. The varieties offered below are the very finest sorts. Our Spring Floral Guide describes them even more fully. Plant after October 15th and before the ground freezes.

\section{APPLE}

Dwarf Bismarck-Bears good fruit at 3 feet high.

Prices, nice one-year trees, 25c. each; 3 for $65 \mathrm{c}$.; $\$ 2.25$ per doz., postpaid. Two-year trees, 35c. each: 3 for 90c.; $\$ 3.00$ per doz., by express, at purchaser's expense.

\section{CURRANT}

Crunells or Gooseberry Currant-Makes a hardy vigorous bush, 2 or 3 feet high, enormously productive, and highly valued for cooking and making jelly. $15 \mathrm{c}$. 2 for $25 \mathrm{c}$, postpaid. Two-year size, 20c. each, 3 for $45 \mathrm{c}$., by express.

\section{GRAPES}

McPike-New and a wonderful prize winner. Large and deep blue black. 1-year, 25c.; 2-year, 35c., postpaid.

Campbell's Early-Glossy black and excellent every way. One-year, 20c. each, $\$ 1.75$ per doz.; two-year, 35 c. each, $\$ 2.50$ per doz.

Concord-The well-known "stand-by."

Niagara-The best white grape, excellent.

Brighton-Early, large and good, amber color.

Worden-Large and black, excellent quality.

Diamond-Best early white, fine for family use.

Price, except where noted-One-year, 15c. each, $\$ 1.10$ per doz.; two-year, $25 \mathrm{c}$. each, $\$ 2.00$ per doz., postpaid. Set of 7 one-year vines, $85 \mathrm{c}$.; set of 7 two-year vines, $\$ 1.75$ postpaid.

\begin{tabular}{|c|c|c|c|}
\hline \multicolumn{4}{|c|}{ INDEX TO BULBS } \\
\hline apanthus & 0 & & 1 \\
\hline (African Lily). & 22 & 25 & \\
\hline . . 20 & $\mathrm{Cul}$ & Hyacinths, Best Named & \\
\hline 20 & $\mathrm{Cy}$ & “ Separate Colors. & logalum \\
\hline .20 & 17 & "Beds ...... & \\
\hline & & “Roman.. & \\
\hline Freesia) & $15-17$ & $\because$ Feathered and Grape 9 & $\mathrm{P}$ \\
\hline un & da . & “ Mi & \\
\hline tar of Bethle- & & “ Musk & xican Lily \\
\hline . . 24 & Cracker & Iris ... & \\
\hline 25 & $23-25$ & Ismene Calathena & \\
\hline $\mathrm{Li}$ & .25 & $25-41$ & ow Flake \\
\hline . & ese) & .17 & \\
\hline & Gl & & \\
\hline & & & \\
\hline 1 & G & 18 & 10 to $14-43-44$ \\
\hline & ssus & the Valley & Tul \\
\hline iese & cre & osa Tulip. & Zephy ranthes \\
\hline
\end{tabular}

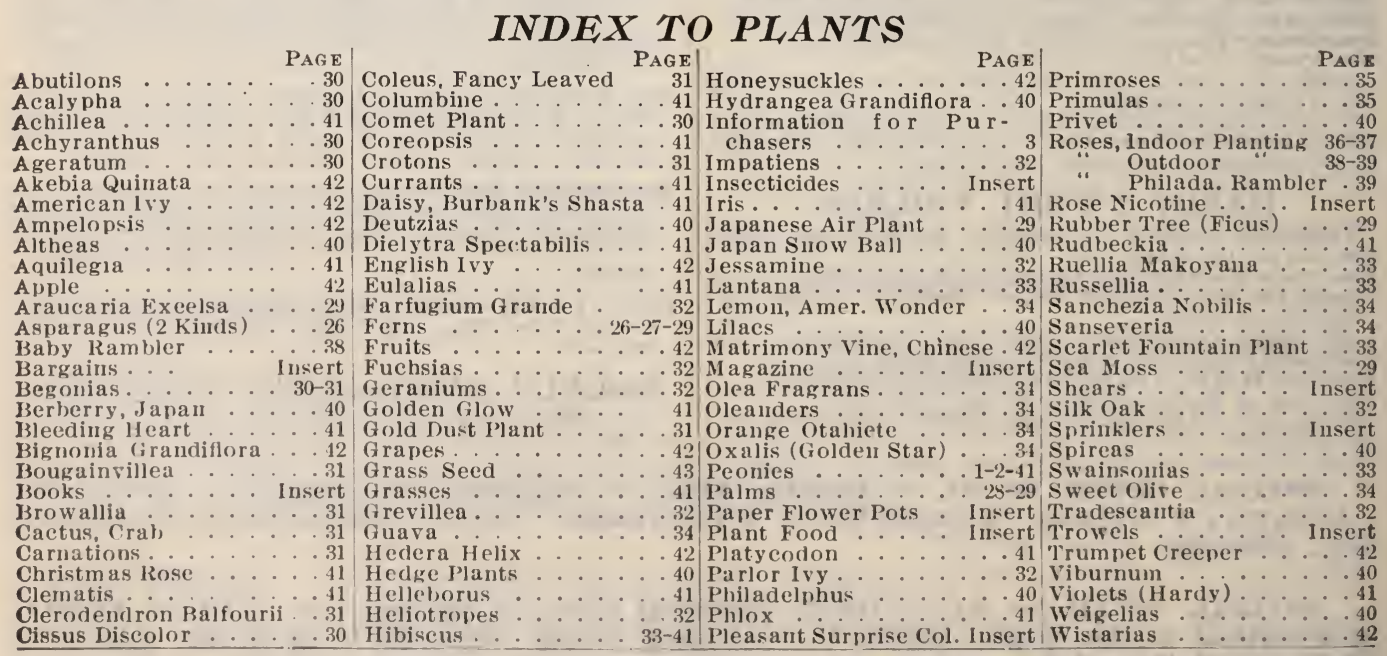




\section{Choice C. \& J. Standard Tulips}

THE TULIP is without doubt Queen of the Spring Flowering Bulbs. Magnificent is the show 1 of brilliant colors they make in the early Spring and they're so easy to grow that anyone can succeed with them and have a glorious display anywhere. From the entire list we have selected Three of the Best to be had for either bedding or forcing, as follows :

\section{RED AND GOLD \\ 1. Keizer Kroon \\ (Crown Imperial)}

One of the oldest and grandest Tulips in cultivation. A Tall grower, beautifully colored with rich crimson red-broadly edged with gold-(see back cover page.)

4c each; 35c per Doz.

$\$ 2.50$ per 100 postpaid.

\section{YELLOW}

\section{Ophir D’or}

Superior in many ways to Chrysolora and other yellow Tulips. Its finely formed flowers on tall strong stems are unusually large. Color, a deep rich golden yellow.

3c each; 30c per Doz. $\$ 2.00$ per 100 postpaid.

\section{CRIMSON}

\section{Rex Rubrorum}

One of the best among the double early varieties, of compact growth, well proportioned flowers, beautiful rosy carmine shading to a crimson red-extra good for bedding.

4c each; 35e per doz.

$\$ 2.50$ per 100 postpaid.

Special Offer No. 4,-12 Bulbs (in 3 kinds, as above) 30c postpaid.

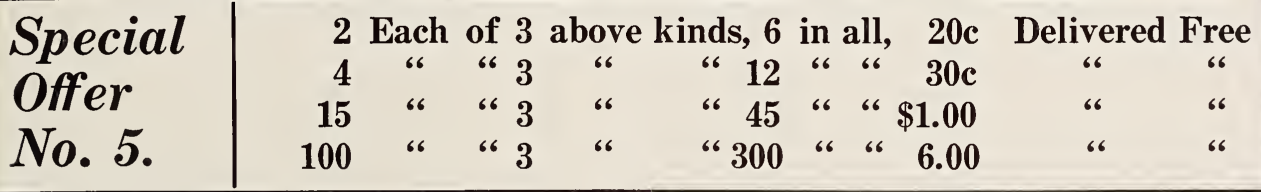

COMPLETE ASSORTMENT OF SPECIALLY SELECTED TULIPS,

Best named varieties, Single Early Tulips,

See PAge 10

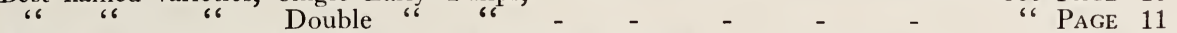

May flowering, Cottage Garden \& Miscellaneous Tulips - _ _ - $\quad$ “ PAgEs 12 \& 13

Tulips for making beds of White, Crimson, Pink, Yellow or Variegated - _ " PAGE 14

SINGLE OR DOUBLE (any color), per doz., 30c; per 100, $\$ 1.75$; per $1000, \$ 14.00$ ) All delivered

DOUBLE MIXED, - $\quad-\quad-\quad \cdots 25 \mathrm{c} ; \quad “ 1.35$; $\quad “ 10.00\}$ free at these

SINGLE, MIXED, - - - $\quad$ " $25 \mathrm{c} ; \quad$ “ $1.35 ; \quad$ “ 9.00 prices

(See suggestions outlined on page 14)

AUTUMN IS AN EXCELLENT TIME FOR SEEDING DOWN NEW LAWNS OR RENOVATING OLD ONES.

\section{Use C. \& J. Velvet Green Lawn Grass Seed.}

$\mathbf{O}$

UR VELVET GREEN LAWN GRASS SEED is not excelled by any for producing a smooth, even, velvety-green sward that will withstand drought and hard usage, and always make a handsome appearance. In seeding down a lawn or grass plot, three things are necessary to insure success : First, to prepare the ground so as to have a fine, smooth seedbed ; second, to put on plenty of seed; never less, but rather more, than the directions call for ; third, to start the lawn-mower as soon as the weeds (which are always in the ground and sure to start first) are tall enough to catch the machine, and keep them mowed off close till the grass has time to start and become well established. The seed should be lightly raked in and finished with a roller. Apply any good commercial fertilizer as a top dressing when needed. One quart of seed is enough for three hundred square feet (fifteen by twenty feet), or at the rate of five bushels to the acre. Lawns should be kept neatly mowed, which induces a clean, even growth of fresh, lively green.

Price by mail, postpaid 25 cts. per quart; two quarts for 45 cts.; in bulk, purchaser paying express charges, $\$ 1.50$ per peck; $\$ 5.00$ per bushel of $20 \mathrm{lbs}$.

\section{Our New Floral Guide For 1909}

will be sent you early next year, if you send us an order this Fall. It will contain 136 pages-about Roses and 100's of other choice plants; also Seeds, Bulbs, Fruits, etc.all carefully arranged, beautifully illustrated and conservatively written. It has been called one of the most helpful and reliable catalogs published. Next year we expect to make it better still. To our regular customers it will be sent promptly - to all others who express an interest - free on request. 


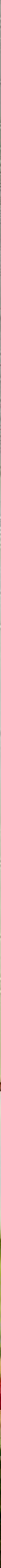

